UNIVERSIDADE ESTADUAL PAULISTA "JULIO DE MESQUITA FILHO" FACULDADE DE CIÊNCIAS AGRÁRIAS E VETERINÁRIAS CÂMPUS DE JABOTICABAL

\title{
INFLUÊNCIA DO PREPARO DO SOLO EM ÁREA DE REFORMA DE CANAVIAL NA QUALIDADE FÍSICA DO SOLO E NA CULTURA DO AMENDOIM
}

Cristian Luarte Leonel

Orientadora: Profa. Dra. Maria Ap. Pessôa da Cruz Centurion Co-orientador: Prof. Dr. José Frederico Centurion

Tese apresentada à Faculdade de Ciências Agrárias e Veterinárias-Unesp, Câmpus de Jaboticabal, como parte das exigências para a obtenção do título de Doutor em Agronomia (Produção Vegetal).

JABOTICABAL - SÃO PAULO - BRASIL

Fevereiro de 2010 


\section{DADOS CURRICULARES DO AUTOR}

CRISTIAN LUARTE LEONEL, nascido em 14 de setembro de 1977, em Ribeirão Preto - SP. Em 1998 ingressou no curso de Agronomia na Universidade Federal de Lavras (UFLA), em Lavras - MG, obtendo o titulo de Engenheiro Agrônomo em 2003, quando começou a prestar assistência técnica pela Bayer Crop Science em Patos de Minas-MG, em dezembro de 2004 transferiu-se para Basf-SA na região da Alta Mogiana no interior de São Paulo. Em agosto de 2004 ingressou no curso de Mestrado em Produção Vegetal pela Universidade Estadual Paulista - Faculdade de Ciências Agrárias e Veterinárias (FCAV/UNESP), Jaboticabal - SP, obtendo o titulo de Mestre em Produção Vegetal em fevereiro de 2006. Em março de 2006 ingressou no curso de Doutorado por essa mesma Universidade, conseguindo o titulo de Doutor em Produção Vegetal em fevereiro de 2010. Atualmente é Assessor Técnico de Pesquisa e Desenvolvimento da Stoller do Brasil LTDA. 
“O período de maior ganho de conhecimento e experiência é o período de maior dificuldade na vida de cada um " Dalai Lama

“Arrisque-se !!! Toda vida é um risco... O homem que vai mais longe é geralmente aquele que está disposto a fazer e a ousar. $O$ barco da segurança nunca vai muito além da margem " Dale Carnegie 


\section{AGRADECIMENTOS}

A DEUS pela vida, saúde e contínuo amparo.

A Universidade Estadual Paulista - Faculdade de Ciências Agrárias e Veterinárias (FCAV/UNESP), Jaboticabal - SP. Aos Departamentos de Produção Vegetal e Solos e Adubos e a Fazenda de Ensino e Pesquisa, pela oportunidade de realização do curso de Doutorado.

A CAPES pelo suporte financeiro.

Aos meus pais Osvaldo Leonel e Maria de Lourdes da S. C. Leonel e ao meu irmão Bruno O. Leonel pelo apoio, incentivo, confiança e solidariedade. Ao meu querido tio Armindo e a minha querida tia Aurora pelo exemplo de superação.

A minha querida tia Magali pelos conselhos e sugestões.

A professora Maria Aparecida Pessôa da Cruz Centurion pela orientação, incansável dedicação e sugestões imprescindíveis para conclusão desse trabalho e para minha formação profissional, e pela confiança e amizade.

Ao professor José Frederico Centurion pelas grandes contribuições na condução, orientação, correção do trabalho e, principalmente pela dedicação, paciência e grande amizade.

Aos professores José Frederico Centurion, Julio César Durigan, Núbia Maria Corrêa, Ruy Casão Junior, Amauri Nelson Beutler, Renato de Mello Prado, Edson Luiz Mendes Coutinho, Marcílio Vieira Martins Filho, Carlos Eduardo Angelli Furlani, Jorge da Silva e Vitório Barato Neto pelas disciplinas ministradas no curso e pela amizade.

A banca examinadora (Itamar Andriolli, Gisele Herbst Vazquez, Marlene Cristina Alves, Edson Lazarini e a professora Maria Aparecida P. da C. Centurion) pelas sugestões e correções para uma melhoria da Tese).

A professora Durvalina Maria Mathias dos Santos (FCAV/UNESP) pelo empréstimo do scanner para avaliação das raízes.

Aos amigos (as) Bruno (Gaucho), Cesinha, Marlon (Tchuscado), Disnei, Batata (Compadre), Gustavo (Barrigas), Franco (Barrigada), Marcelo (Pêra), Danilo, Matheus (Dumont), Ricardo (Galinho mudo), Airton (Tirso), Leyser, Ricardo (Monge), Renan 
(Verme), Eduardo (Van Dame), Thiago (Véio), Gustavo (Batatinha), Vidal (Vidalmansa), Romero, Zé Lima Jr., Thiago (Filó), Ronaldo, Saulo, João, Lucas, Augusto, Mauricio Rossi, Paulo Augusto, Glaucio, Eduardo, Sebastião, Hilton, Rodrigo, Stella, Fernanda, Daniele, Viviane, Cintia (Pin), Magnólia, Cléia, Daniela (Gaucha), Daniela (Loira), Fabiana, Bacaninha, Helena, Beatriz (Nutela) e Gisele (irmã) pelo apoio e amizade.

Em especial aos grandes amigos José Lima Junior e Bruno G.T.L.Vieira pela imensa contribuição, ajuda e sugestões para conclusão desse trabalho.

A Coplana por ceder a área e equipamentos para condução dos experimentos.

Aos funcionários do Departamento de Solos e Adubos Dejair, Orivaldo (Nenê) e Orivaldo (Gomes) e aos funcionários do Departamento de Produção Vegetal Monica, Marisa, Tito, Osmar, Sr. Sebastião, Rubens (Faro Fino), Geraldo, Mauro e Gabi, pela paciência e presteza na realização dos trabalhos e pela grande amizade construída.

Aos funcionários da Fazenda de Ensino e Pesquisa pela prestatividade na realização dos trabalhos de campo.

A Stoller do Brasil LTDA pelo apoio e incentivo a conclusão deste trabalho.

Em fim, a todos professores, funcionários, amigos e colegas que conheci, pelo apoio, sugestões, amizade e agradável convivência. 
Aos meus pais Osvaldo e Maria de Lourdes e ao meu irmão Bruno pelo grande incentivo.

\title{
OFEREÇO
}

\author{
À minha noiva, \\ Aline Vanessa Betiol \\ Pela preocupação e apoio nos momentos difíceis \\ Pela amizade, companheirismo, carinho, dedicação e amor \\ incondicional em todas as horas \\ Pela forma como mudou minha vida... \\ E pela compreensão sobre minha ausência durante o \\ desenvolvimento deste trabalho.
}




\section{SUMÁRIO}

página

RESUMO ..vii

ABSTRACT. viii

CAPÍTULO 1 - CONSIDERAÇÕES GERAIS. 1

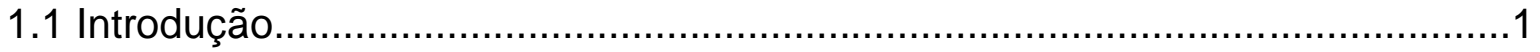

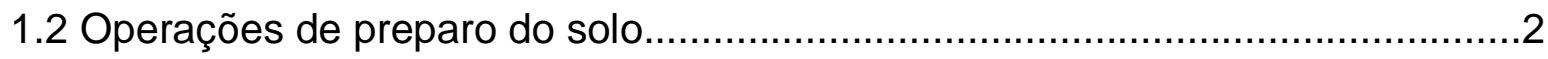

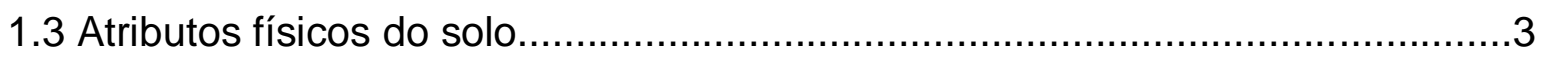

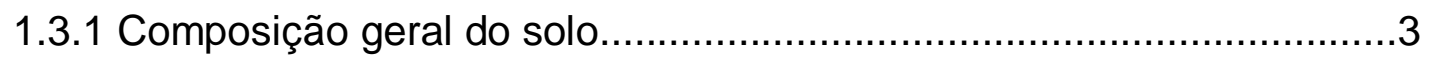

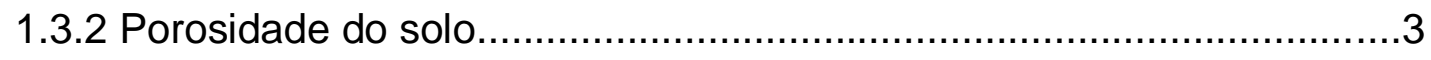

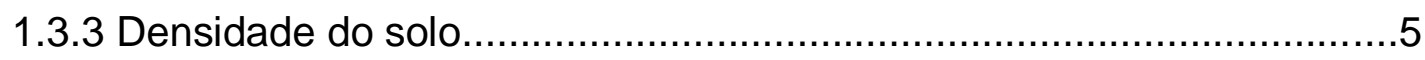

1.3.4 Resistência mecânica do solo à penetração.......................................5

1.3.5 Estabilidade dos agregados.......................................................

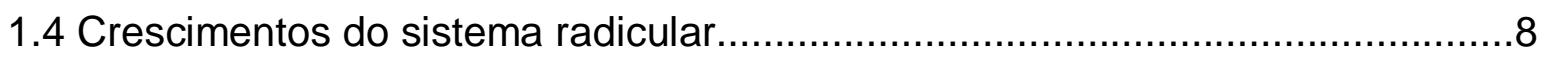

CAPÍTULO 2. Influência do sistema de preparo do solo em áreas de reforma de canavial sobre a estabilidade de agregados.

CAPÍTULO 3. Influência do sistema de preparo do solo em áreas de reforma de canavial nos atributos físicos e crescimento radicular do amendoim. .32

CAPITULO 4. Influência do sistema de preparo do solo em área de reforma de canavial nos componentes de produtividade do amendoim. 


\section{INFLUÊNCIA DO SISTEMA DE PREPARO DOSOLO EM ÁREA DE REFORMA DE CANAVIAL NA QUALIDADE FÍSICA DO SOLO E NA CULTURA DO AMENDOIM}

RESUMO: O objetivo do presente trabalho foi avaliar diferentes sistemas de preparo do solo: Plantio Convencional (PC), Cultivo Mínimo (CM) e Plantio Direto (PD), dois níveis de palhada remanescente da cana-de-açúcar colhida mecanicamente, nos atributos físicos do solo, crescimento radicular e componentes de produtividade do amendoim. As cultivares IAC Tatu ST e Runner IAC 886 foram semeados no dia 23 de novembro de 2007, em Latossolo Vermelho distrófico no município de Guariba (SP). O delineamento experimental utilizado foi em blocos casualizados, com parcelas subsubdivididas com seis repetições. Os tratamentos foram constituídos por três diferentes sistemas de preparo do solo, dois níveis de palhada (sem e com) e três profundidades de coleta de solo: 0,03-0,06; 0,13-0,16 e 0,23-0,26 m, para determinação da resistência mecânica do solo à penetração, densidade e porosidade do solo, bem como, a determinação da estabilidade de agregados e crescimento radicular nas profundidades de 0-0,1 e 0,1-0,2 m. Os maiores valores de densidade do solo, resistência mecânica do solo à penetração e menor valor de macroporosidade encontrados no PD na camada mais superficial, influenciaram negativamente 0 crescimento radicular. A densidade de $1,44 \mathrm{Mg} \mathrm{m}^{-3}$ e resistência mecânica do solo à penetração de 1,56 MPa encontradas no PC na camada de 0,13-0,16 m limitou o crescimento das raízes abaixo dessa camada. O PD e o CM proporcionaram maior agregação do solo com relação ao PC, nas duas camadas avaliadas. Os sistemas de preparo onde as $15 \mathrm{tha}^{-1}$ de palhada remanescentes da cana-de-açúcar permaneceram sobre a superfície do solo sem incorporação, influenciou negativamente a produtividade e rendimento dos grãos do amendoim para os dois cultivares.

Palavras-Chave: Plantio direto, desenvolvimento radicular, palhada de cana-de-açúcar, Arachis hypogaea L. 


\section{SOIL TILLAGE SYSTEM INFLUENCE IN SUGARCANE RENOVATION AREA IN THE SOIL PHYSICAL QUALITY AND PEANUT CROP}

ABSTRACT: The aim of this study was evaluate different soil tillage systems: conventional tillage (CT), chisel tillage (CHT) and no-tillage (NT) with and without straw remainder of sugarcane harvested mechanically, the soil physical properties, root growth and peanuts yield. The cultivars IAC Tatu ST and Runner IAC 886 were sowed in Haplustox on 27 november 2007 in the town Guariba-SP. Randomized complete block design in split-split- plots with six replications were used. Three different tillage systems, two straw level (with and without) and three depths: 0.03-0.06; 0.13-0.16 and 0.23-0.26 $\mathrm{m}$, for determining the soil mechanical resistance to penetration, density and porosity. For determine root density, root surface, root diameter and root dry mass, soil samples were collected in two layers $(0-0.10$ and $0.10-0.20 \mathrm{~m})$. Most value soil density, mechanical resistance to penetration and smaller values macroporosity found NT superficial soil layer negatively influenced root growth. The density of $1.44 \mathrm{Mg} \mathrm{m}^{-3}$ and mechanical resistance to penetration of $1.56 \mathrm{MPa}$ found in the CT layer $0.13-0.16 \mathrm{~m}$ limited the roots growth downwards this layer. In the two layers evaluated, the NT and CHT provided greater soil aggregation in relation CT. The tillage systems where $15 \mathrm{t}$ ha

1 sugarcane straw remnants remained on the soil surface without incorporation, prevented the gynophore penetration in to soil negatively influency peanut productivity and grain yield.

Key words: No tillage, root development, sugar cane straw, Arachis hypogaea L. 


\section{CAPITULO 1. CONSIDERAÇÕES GERAIS}

\subsection{Introdução}

O Brasil atualmente é o $13^{\circ}$ produtor mundial de amendoim, com uma produção de 295,6 mil toneladas, proveniente de uma área de 115,6 mil hectares. A produtividade média dessa leguminosa no Brasil fica em torno de $2.560 \mathrm{~kg} \mathrm{ha}^{-1}$. O estado de São Paulo com uma área cultivada de aproximadamente 81,3 mil hectares e produção de 236,4 mil toneladas é responsável por $77 \%$ da produção nacional de amendoim (AGRIANUAL, 2009). Além disso, essa cultura é de grande importância para o estado de São Paulo, uma vez que constitui-se em alternativa de rotação de culturas nas áreas de reforma de canavial.

A expansão das fronteiras agrícolas para produção de amendoim no Brasil ocorreu no final do século $X X$, quando foi introduzida a completa mecanização em todas as fases do seu cultivo. Até então, o amendoim era cultivado, exclusivamente, em solos preparados de forma convencional, por meio de arações e gradagens, com o objetivo de deixar o solo poroso para melhorar a germinação, o crescimento radicular e o pleno desenvolvimento da cultura. Esse sistema de cultivo, quando mal conduzido, além da compactação subsuperficial do solo, ocorre uma rápida degradação e grandes perdas por erosão, o que levou aos pesquisadores a refletirem sobre a sustentabilidade do solo ao longo dos anos. Desta forma, iniciaram-se estudos com o preparo do solo por meio de escarificadores e subsoladores denominado de cultivo mínimo, e sem revolvimento e preparo prévio do solo denominado de sistema de plantio direto (PD).

A implantação e o crescimento do PD de amendoim no Brasil ainda é lento, por causa de problemas técnicos referentes a mecanização e à implantação da cultura sem adequação das áreas, principalmente no que se refere a compactação do solo nas áreas de reforma de canavial. Além disso, com o passar dos anos o tráfego de máquinas sobre o solo, principalmente quando este está com umidade acima da 
capacidade de campo causam compactação e redução da produtividade das culturas, principalmente para os solos mais argilosos.

\subsection{Operações de preparo do solo}

O preparo tem por objetivo melhorar as condições do solo para favorecer a germinação das sementes e o crescimento e desenvolvimento das plantas, facilitar o movimento de água e ar, controlar plantas indesejáveis e, em alguns casos, auxiliar no manejo dos resíduos culturais (LARSON \& GILL, 1973). Por outro lado, quando mal executado, também apresenta efeitos negativos, pois o preparo excessivo reduz a rugosidade da cobertura do solo (BERTOL et al. 2000), pulveriza a superfície e forma camadas compactadas na subsuperfície (DALLA ROSA, 1981), além de facilitar a erosão hídrica (HERNANI et al., 1997), também limita o crescimento das raízes, o desenvolvimento e a produção das culturas (SILVA et al., 2000b).

No sistema de preparo convencional do solo, a grade aradora tem sido o equipamento mais utilizado. Normalmente a grade trabalha o solo a pouca profundidade e apresenta alto rendimento de campo, porém o uso contínuo desse implemento pode levar à formação de camadas compactadas, chamadas "pé - de - grade" (SILVA, 1992). Os arados, tanto de disco como de aiveca são equipamentos pouco utilizados, porque requerem maior tempo e energia para a sua operação (KLUTHCOUSKI et al., 2000).

Segundo HAKANSSON et al. (1988), o sistema de preparo convencional do solo ocasiona compactação subsuperficial em virtude da mobilização e descompactação mecânica da camada mobilizada, ao mesmo tempo em que a carga aplicada apresenta efeito acumulativo em subsuperfície ao longo dos anos. SAXON et al. (1988) estudaram a influência das práticas culturais na compactação de solos de textura franco-siltosa mecanizados superficialmente todos os anos e verificaram que as práticas culturais modificam a densidade do solo e, conseqüentemente, a infiltração de água, especialmente nas áreas com intensa mecanização, causando impacto negativo nas condições físicas e nos processos químicos e biológicos do solo. 


\subsection{Atributos físicos do solo}

\subsubsection{Composição geral do solo}

O solo é constituído de um sistema composto de três fases: sólida, líquida e gasosa. A fase sólida é formada por matéria inorgânica e matéria orgânica. Estes dois componentes formam o chamado "matrix" do solo. A porção mineral consiste de partículas de vários tamanhos, resultantes da decomposição das rochas que deram origem ao solo. A fração orgânica tem sua origem no acúmulo dos resíduos vegetais e animais, ocorrendo no solo em diferentes estágios de decomposição, contando, ainda, com organismos vivos e em atividade. A fase líquida é constituída pela solução do solo ou água do solo e compõem-se de água, sais em dissolução e matéria coloidal em suspensão. A fase gasosa é o ar do solo, assim denominado pelo fato de sua composição diferir da que ocorre no ar atmosférico, quanto à proporção porcentual de seus elementos. As fases sólida, líquida e gasosa guardam entre si certa proporção, porém, esse equilíbrio pode ser afetado com as variações da temperatura, pressão, luz, atividades dos microrganismos, variação no conteúdo de água do solo, absorção de íns pelas raízes e principalmente pela compactação do solo. Um solo contendo seus componentes em proporção suposta ideal, deve ter cerca de $50 \%$ de porosidade total e $50 \%$ de volume de sólidos; os sólidos devem estar assim divididos: $45 \%$ de matéria mineral e $5 \%$ de matéria orgânica em peso; a porosidade do solo pode ser classificada em macroporosidade e microporosidade (KIEHL, 1979).

\subsubsection{Porosidade do solo}

A porosidade é a relação entre a proporção de espaços que podem ser ocupados por líquidos e ar em relação ao espaço ocupado pela massa de solo, normalmente a porosidade ideal é de $50 \%$. A perda da porosidade está relacionada diretamente com a 
compactação que reduz o tamanho dos poros. A porosidade total é dividida em macroporos e microporos, sendo o solo um emaranhado de capilares de diferentes formas e tamanhos, possuindo grande influência na capacidade do solo em armazenar água (ANDRADE \& SANTOS, 2004).

Tanto a estrutura (arranjo das partículas no solo), quanto à textura do solo (distribuição de tamanho das partículas que constituem o solo - areia, silte e argila), conferem a este um espaço poroso e um arranjo de partículas característico, que por sua vez, afetam as propriedades hídricas e físicas do solo (ANDRADE et al. 1998).

CAMARGO \& ALLEONI (1997) dizem que o tamanho dos poros determina o potencial de água neles retida e, conseqüentemente, a sucção necessária para esvaziálo, pois quanto maior o tamanho do poro, menor será a sucção a ser aplicada para retirar a água, e quanto menor o tamanho do poro maior será a sucção para retirar a água, assim se o diâmetro de um tubo diminui $1 / 3$ do tamanho original o volume do fluxo diminuirá $1 / 81$ do original e como a compactação diminui a quantidade de poros grandes, ela tem grande influência na transmissão de água em um solo saturado.

A distribuição do diâmetro dos poros no solo tem um papel preponderante nesse contexto. Inúmeras classificações do diâmetro de poros foram citadas na literatura, destacando-se uma forma mais simplificada que separa os poros em duas classes: macroporos, quando os poros têm diâmetro maior do que 0,06 mm, e microporos, quando os poros são menores do que $0,06 \mathrm{~mm}$, como a proposta por KIEHL (1979). Os microporos são definidos também como poros de armazenamento de água às plantas.

A macroporosidade é diretamente relacionada com a densidade do solo. E quando ocorre compactação os primeiros poros a desaparecer são os macroporos que são responsáveis pela sua aeração (PRIMAVESI, 1987). Os macroporos constituem a rota principal ao crescimento das raízes, mostrando que solos mal estruturados prejudicam o crescimento radicular (CAMARGO \& ALLEONI, 1997). Segundo THOMASSON (1978) e SECCO et al. (2004), os solos devem possuir uma macroporosidade mínima de $10 \%$ para o crescimento e desenvolvimento satisfatório das plantas, indicando condições de aeração adequadas para as raízes das plantas, revelando que, mesmo sob elevados potenciais da água no solo, a difusão de oxigênio às raízes não é impeditiva 
(TORMENA et al., 2004). Sabe-se, no entanto, que estes valores são apenas uma referência, pois a taxa de difusão gasosa no solo depende da profundidade e densidade do sistema radicular, temperatura do solo, tortuosidade do espaço poroso, entre outros.

\subsubsection{Densidade do solo}

A densidade do solo é também chamada de densidade global ou densidade aparente do solo, sendo esta bastante afetada pelo manejo do solo efetuado pelo homem (ANDRADE et al. 1998). Pode-se dizer com certa restrição que ela é a medida quantitativa mais direta da compactação do solo (CAMARGO \& ALLEONI, 1997).

A densidade do solo expressa a relação entre a massa de solo seco e o volume total e constitui um grau de arranjamento das partículas do solo, e mesmo os solos que nunca foram cultivados podem apresentar camadas adensadas em subsuperfície. Quanto maior a densidade do solo, maior será a dificuldade de desenvolvimento das raízes das plantas e ao preparo, sendo por isso solos mais soltos mais favoráveis a mecanização, mesmo que isto implique em menor disponibilidade de água para as plantas (ANDRADE \& SANTOS, 2004).

A compactação causada pelo homem reduz o volume total de solo para uma mesma massa fazendo com que a densidade do solo aumente, afetando a capacidade de retenção de água no solo e o movimento desta (ANDRADE et al. 1998).

Para solos arenosos, de maneira geral, os valores médios de densidade do solo variam entre 1,2 a $1,4 \mathrm{~kg} \mathrm{dm}^{-3}$, sendo maiores do que em solos argilosos que apresentam densidades entre 1,0 a $1,2 \mathrm{~kg} \mathrm{dm}^{-3}$, devendo-se tomar cuidado ao considerar um valor absoluto de densidade crítica para solos compactados ou não (CAMARGO \& ALLEONI, 1997).

\subsubsection{Resistência mecânica do solo à penetração}


Alguns atributos físicos são utilizados para caracterizar a compactação do solo, entre estes, a infiltração de água, a porosidade, a densidade do solo e a resistência mecânica do solo à penetração (RP). A penetrometria consiste num método apropriado para avaliar a resistência mecânica do solo à penetração das raízes no solo, devido à facilidade, rapidez e à possibilidade de efetuar grande número de repetições na obtenção de dados, embora possam ocorrer dificuldades na interpretação dos resultados obtidos devido à dependência desses em relação ao conteúdo de água, matéria orgânica e a textura do solo (TAVARES FILHO et al., 1999; BENGHOUGH \& MULLINS, 1990).

A RP é medida normalmente com o penetrômetro, sendo uma relação entre a força exercida para a penetração no solo de uma haste provida de um cone metálico numa extremidade, do qual sua área basal é constante e conhecida (BRADFORD, 1980).

A RP possui boa correlação com o crescimento radicular, uma vez que a elongação das raízes varia de forma inversamente proporcional à sua grandeza. Outro fator importante é que, com a redução do teor de água no solo, ocorre um aumento da RP, decorrente da maior coesão entre as partículas (GERARD et al., 1972). Entretanto, a resistência mecânica do solo à penetração apresenta valores 2 a 8 vezes superiores a máxima pressão axial que a raiz pode exercer (MISRA et al., 1986).

Sabe-se que um solo com valores de resistência mecânica do solo à penetração variando entre 1,0 e 3,5 MPa (MEROTTO \& MUNDSTOCK, 1999), ou de 2,0 a 4,0 MPa, segundo ARSHAD et al. (1996), poderá restringir ou mesmo impedir o crescimento e o desenvolvimento das raízes. MILLER (1987) afirmou que a penetração das raízes pode ser reduzida se a resistência do solo atingir valores da ordem de 3,0 $\mathrm{MPa}$, o que pode resultar em decréscimo no suprimento de água e nutrientes para as plantas.

Neste sentido, o conteúdo de água na capacidade de campo é considerado ideal quando se determina a RP e o crescimento radicular (SMITH et al., 1997), sendo geralmente o conteúdo de água utilizado na maioria dos estudos em que é determinada a RP, a fim de que seja possível fazer inferência com relação ao valor crítico de 2,0 MPa (SILVA et al., 1994). 
Em compactações do solo que impedem o crescimento da raiz principal ocorre proliferação das raízes laterais e quando o impedimento é tanto na vertical como na horizontal ocorre aumento de diâmetro tanto da raiz principal como das raízes laterais (CAMARGO \& ALLEONI, 1997).

\subsubsection{Estabilidade dos agregados}

A estabilidade dos agregados tem sido utilizada como indicador da condição estrutural do solo, por ser sensível as suas alterações em decorrência do sistema de manejo adotado. De acordo com SIX et al. (2000) o indicador da estrutura do solo é a estabilidade de agregados. Sendo que, o uso e manejo do solo, a intensidade e o tempo de utilização promovem alterações na agregação do solo (ROTH \& PAVAN, 1991).

Em um mesmo tipo de solo, diferentes práticas de manejo poderão afetar diretamente os processos de formação dos agregados (CASTRO FILHO et al., 1998). O sistema de plantio direto, ao manter os resíduos culturais na superfície, poderá aumentar a matéria orgânica e melhorar a agregação do solo em relação ao plantio convencional (CARPENEDO \& MIELNICZUK, 1990), cujos agregados, maiores e menos densos, favorecem a infiltração de água no solo (CASTRO FILHO et al., 1998). Por outro lado, no plantio convencional, a ruptura dos agregados ocasionada pelo preparo do solo poderá acelerar as perdas de carbono-orgânico pela oxidação da matéria orgânica (MENDONÇA \& ROWELL, 1994).

Práticas intensivas de cultivo aliado à ausência de resíduos vegetais sobre a superfície do solo causam a redução da estabilidade dos agregados, o selamento superficial, reduz a infiltração de água no solo e, conseqüentemente, predispõe o solo a ação dos processos erosivos (ROTH et al., 1991). Por outro lado, as práticas conservacionistas que enfatizam a rotação de culturas, a proteção do solo por resíduos vegetais e o não revolvimento do solo, tem se mostrado eficientes em aumentar a estabilidade de agregados (CARPENEDO \& MIELNICZUK, 1990). A sucessão de 
gramíneas com leguminosas proporciona aumentos na agregação do solo, devido ao sistema radicular das gramíneas e à taxa de decomposição das leguminosas (CAMPOS et al., 1999; WOHLENBERG et al., 2004). Outros autores relataram maior formação e estabilidade de agregados em solos cultivados com gramíneas a leguminosas, devido à alta densidade de raízes, às periódicas renovações do sistema radicular e à uniforme distribuição dos exsudatos no solo, que estimulam a atividade microbiana, cujos subprodutos atuam na formação e estabilização dos agregados (SILVA \& MIELNICZUK, 1997).

\subsection{Crescimento do sistema radicular}

A primeira raiz é gerada do crescimento apical do embrião que produz ramificações laterais designadas raízes secundárias. Estas por sua vez constituem o sistema radicular primário. As demais raízes que se desenvolvem são chamadas adventícias. Sendo dividido em aprumado e fasciculado, sendo o primeiro com raiz principal e o segundo em forma de cabeleira (MEYER et al., 1965).

As raízes são cobertas por pêlos nas células individuais da epiderme da raiz. Os pêlos radiculares possuem grande superfície e vacúolo desenvolvido, que possuem um muco que protege externamente a raiz (OVERBEER, 1970).

Para o crescimento da raiz, ocorre surgimento de novas células, aumentando de volume na direção do eixo da raiz, a divisão e o elongamento têm como conseqüência empurrar a região de crescimento e coifa através do solo e originar o elongamento da raiz (MEYER et al., 1965).

As raízes estão sempre em crescimento, ao penetrar em novos solos produzem mais pêlos. A argila carregada negativamente retém a água e quanto menor a quantidade de água no solo menor a disponibilidade restringindo o crescimento das plantas (OVERBEER, 1970).

Quanto ao seu desenvolvimento possui padrão morfológico particular para cada espécie, podendo ser: superficial, profundo ou múltiplas camadas. Sistemas radiculares 
extensivos exploram grandes volumes de solo e locais mais distantes e úmidos com direção ao lençol freático. Solos rasos e compactados impedem o crescimento e ramificação do sistema radicular. A principal causa para o suprimento de água deficiente é o crescimento inadequado do sistema radicular (LARCKER, 2000).

A profundidade do sistema radicular é característica de cada espécie, mas os atributos físicos do solo podem variar a sua distribuição e camadas compactadas podem até impedir seu desenvolvimento (MEYER et al., 1965).

Pode-se diagnosticar a compactação por meio de métodos científicos ou práticos, sendo que o primeiro requer aparelhos específicos e são de grande confiabilidade, enquanto que os práticos são eficientes e informam o resultado de forma mais rápida (CARVALHO FILHO et al., 2004).

Os sintomas de compactação podem ser observados tanto no solo como na planta. Dentre os sintomas observados nos solos compactados podem ser destacados a presença de crostas, aparecimento de trincas nos sulcos de rodagem do trator, zonas endurecidas, empoçamento de água, erosão hídrica excessiva, presença de resíduos vegetais parcialmente decompostos muitos meses após sua incorporação, necessidade de maior potência das máquinas de cultivo, entre outros. Já no vegetal podem ser destacadas as baixas emergências das plântulas, folhas amarelecidas, sistema radicular raso e horizontal, raízes mal formadas e tortas, entre outros (PEDROTTI \& DIAS JÚNIOR, 1996).

A compactação causa algumas modificações nos solos que são: aumento da resistência mecânica do solo à penetração radicular, redução da aeração, alteração do fluxo de água e calor e da disponibilidade de água e nutrientes, e nas plantas: emergência lenta, sistema radicular raso, plantas desuniformes, deficiências nutricionais, dentre outros (CAMARGO \& ALLEONI, 1997).

Os atributos físicos mais comumente utilizados na identificação do estado de compactação do solo são: a resistência mecânica do solo à penetração, densidade do solo, volume de macro e microporos e a porosidade total dos solos, já apresentados. 
Tanto em casa de vegetação (ROSOLEM et al., 1994; QUEIROZ-VOLTAN et al., 2000; GUIMARÃES et al., 2002) como no campo (MERTEN \& MIELNICZUK, 1991; SILVA \& ROSOLEM, 2002) as raízes da soja apresentam dificuldades em penetrar nas camadas compactadas. Este efeito é parcialmente compensado por um maior crescimento radicular em camadas menos compactadas.

Segundo CAMARGO \& ALLEONI (1997), quando a compactação reduz o tamanho dos poros a ponto de impedir a passagem da raiz principal, ocorre uma intensificação da formação de raízes laterais com diâmetros menores, resultando em um sistema radicular denso e raso, que no campo dificilmente sobrevive a condições de seca. Este fato foi comprovado por ROSOLEM et al. (1994), que verificaram aumento na densidade radicular na camada de 0-0,05 m, associado ao menor crescimento radicular na camada compactada.

QUEIROZ-VOLTAN et al. (2000), verificaram que a densidade de raízes de soja (cv. IAC-14) não variou; todavia a massa de matéria seca das raízes aumentou inicialmente e posteriormente diminuiu com o aumento da compactação do solo, na camada de 0,0-0,20 m. Esse mesmo comportamento foi verificado por MORAES et al. (1995). Estes resultados indicam que o desenvolvimento de raízes em solos compactados deve ser estudado por camadas, no sentido de avaliar a sua distribuição no perfil de solo.

Segundo PABIN et al. (1998), a redução de $40 \%$ no comprimento radicular é crítica à produtividade das plantas, em solo arenoso. CINTRA \& MIELNICZUK (1983) verificaram redução de 50\% no comprimento radicular de várias culturas na resistência do solo à penetração (RP) de 1,10 MPa, em Latossolo Roxo. MIELNICZUK et al. (1985) verificaram redução de $86 \%$ no comprimento radicular da soja, em vasos, quando a RP foi de 2,35 MPa, porém, não decrescendo o peso da massa de matéria seca da parte aérea, em um Latossolo Roxo. ROSOLEM et al. (1994), em vasos, verificaram que na RP de 0,69 MPa houve redução de $50 \%$ no comprimento radicular da soja, em Latossolo Vermelho Escuro.

Para ROSOLEM et al. (2002), a compactação não alterou o diâmetro radicular, a densidade, superfície e massa seca total de raízes da soja, porém, afetou a distribuição 
das raízes no perfil. No entanto, ROSOLEM \& TAKAHASHI (1998) obtiveram maior diâmetro radicular em RP > 1,2 MPa para essa mesma cultura. ROSOLEM et al. (1994) também não verificaram alterações significativas no diâmetro médio das raízes de soja na camada compactada de 0,05-0,15 m. Entretanto, GUIMARÃES et al. (2002) verificaram que o diâmetro médio das raízes de feijão aumentou na camada compactada. Segundo MATERECHERA et al. (1992), isso ocorre em decorrência da proliferação de raízes finas laterais, causada pela inibição do alongamento na região apical das raízes, e não da diminuição propriamente dita do diâmetro das raízes.

Em relação ao desenvolvimento de raízes em solos compactados a literatura relata principalmente a redução da profundidade e a redistribuição do sistema radicular, diminuindo o desenvolvimento e a produtividade das plantas (ROSOLEM et al., 2002; BEUTLER \& CENTURION, 2004) e não propriamente o decréscimo da quantidade total de raízes de soja. Assim, essas exploram a camada superficial e um menor volume de solo. Conseqüentemente absorvem quantidades de água e nutrientes, muitas vezes, insuficientes para manter a demanda da parte aérea e para possibilitar a obtenção da produtividade máxima.

PAULETTO et al. (1989) constataram que somente seriam consideradas camadas compactadas aquelas nas quais os valores de resistência mecânica à penetração fossem superiores a $1,72 \mathrm{MPa}$, alertando também para 0 fato de que 0 limite superior de 2,32 $\mathrm{MPa}$ impediria o desenvolvimento do sistema radicular das plantas de milho. Assim como, SILVA JÚNIOR (2001), estudando a variabilidade espacial do índice de cone sob um Latossolo Vermelho Amarelo cultivado com milho, verificou uma tendência de decréscimo da produtividade com o aumento do índice de cone em todas as profundidades estudadas, sendo que tal índice variou, predominantemente na área, entre 1,5 a 2,5 MPa. ROSOLEM et al. (1994), também observaram que o aumento da densidade do solo de 1,03 para $1,72 \mathrm{~g} \mathrm{~cm}^{-3}$ aumentou a resistência mecânica do solo à penetração de 0,05 para 2,0 $\mathrm{MPa}$, causando total impedimento ao crescimento de raízes de milho. Neste contexto, VEEN \& BOONE (1990) relataram que as raízes de milho cessaram o crescimento quando a resistência mecânica do solo à penetração alcançou 4,7 MPa. Contudo, TAVARES FILHO et al. 
(2001) afirmaram que a resistência de um Latossolo Roxo argiloso à penetração de 3,5 MPa não restringiram o desenvolvimento radicular do milho, porém influenciaram a sua morfologia. Assim como ALBUQUERQUE \& REINERT (2001), em um Argissolo Vermelho distrófico arênico, afirmaram que o crescimento radicular da cultura do milho no horizonte B textural foi restringido pela pequena quantidade de macroporos, presença de concreções e elevada saturação por alumínio, porém a elevada densidade do solo $\left(1,29\right.$ a $\left.1,71 \mathrm{~g} \mathrm{~cm}^{-3}\right)$ e a resistência mecânica do solo à penetração (2,6 a 5,0 $\mathrm{MPa}$ ) não afetaram o sistema radicular do milho e que a restrição ao crescimento radicular reduziu a produtividade de grãos do milho em $1.169 \mathrm{~kg} \mathrm{ha}^{-1}$ nos perfis com horizonte $\mathrm{A}$ raso, $35 \mathrm{~kg} \mathrm{ha}^{-1}$ para cada centímetro a menos de espessura de horizonte $\mathrm{A}$ explorado pelas raízes. 


\section{CAPÍTULO 2 - INFLUÊNCIA DO SISTEMA DE PREPARO DO SOLO EM ÁREAS DE REFORMA DE CANAVIAL SOBRE A ESTABILIDADE DE AGREGADOS}

RESUMO - Com a finalidade de proporcionar melhorias ao solo, a reforma dos canaviais é realizada geralmente com leguminosas, principalmente amendoim e soja. Dessa forma, o objetivo deste trabalho foi avaliar diferentes sistemas de preparo do solo: Plantio Convencional (PC), Cultivo Mínimo (CM) e Plantio Direto (PD) sem e com palha remanescente da cana-de-açúcar colhida mecanicamente na agregação do solo, por dois anos consecutivos, durante o cultivo de amendoim após o quinto ano de cultivo com cana-de-açúcar. O experimento foi realizado em Guariba-SP, em um Latossolo Vermelho distrófico. O delineamento experimental utilizado foi em blocos casualizados, em parcelas subsubdivididas, com seis repetições, em que os tratamentos principais se constituíram de três sistemas de preparo do solo: PD; CM (uma operação com escarificador de cinco hastes e rolo destorroador, na camada de 0,20 m); PC (duas passadas de grade intermediária com 24 discos, a uma camada de 0,15 m, uma passada de escarificador e uma passada de grade niveladora com 44 discos, na camada de 0,10 m), os tratamentos secundários de dois níveis de palhada e os tratamentos ternários de duas camadas. Foram coletadas amostras indeformadas do solo nas camadas de 0-0,10 e 0,10-0,20 m para a determinação do diâmetro médio ponderado (DMP) e diâmetro médio geométrico (DMG). Para a safra 2006/2007, o PD e o CM proporcionaram maior agregação do solo com relação ao PC, nas duas camadas avaliadas. Para a safra 2007/2008, na camada de 0-0,10 m, o CM proporcionou maiores valores de agregados com diâmetro $<2,00$ mm em comparação ao PD e PC.

Palavras-Chave: cultivo mínimo, diâmetro médio geométrico, diâmetro médio ponderado, palhada de cana-de-açúcar, plantio direto. 


\section{INTRODUÇÃO}

A degradação da estrutura causa ao solo perda das condições favoráveis ao desenvolvimento vegetal e o predispõe ao aumento de erosão hídrica. A rotação de culturas e o manejo do solo amenizam esses problemas e agem com o intuito de restaurar-Ihe a estrutura.

A formação e a estabilização dos agregados do solo ocorrem mediante a atuação de processos físicos, químicos e biológicos que, por sua vez, atuam por mecanismos próprios, nos quais são envolvidas substâncias que agem na agregação e na estabilização (SILVA \& MIELNICZUK, 1997). A intensidade desses mecanismos influencia a resistência dos agregados à ação das forças desagregantes, que podem ser advindas da capacidade do solo de conservar sua estrutura sob ação da água ou da pressão mecânica (MARCOLAN \& ANGHINONI, 2006).

Os sistemas de manejo do solo podem influenciar diferentemente a estabilidade dos agregados do solo, condicionada ao tamanho dos agregados. A estabilidade dos agregados tem mostrado variação dependente do tipo de manejo do solo e das culturas (CAMPOS et al., 1995). A lavoura intensamente mecanizada é responsável pela redução do conteúdo de matéria orgânica do solo, que é um dos principais agentes de formação e estabilização dos agregados (TISDALL \& OADES, 1982). Por outro lado, os sistemas conservacionistas que recebem um maior aporte de resíduos orgânicos, geralmente têm-se mostrado eficientes em aumentar a estabilidade de agregados (SECCO et al., 2005). Dessa forma, SILVA \& MIELNICZUK (1997) verificaram redução do diâmetro médio ponderado (DMP) dos agregados de 47\% num Latossolo Roxo, quando passaram de uma condição de campo nativo para o preparo convencional com culturas anuais, submetidas a aração e gradagem. Por outro lado, os mesmos autores verificaram aumento da estabilidade dos agregados quando o solo foi submetido ao sistema de plantio direto.

Diante do exposto, o objetivo deste trabalho foi verificar a mudança na estabilidade dos agregados em duas camadas, em função de três sistemas de preparo do solo e dois níveis de palhada remanescente da cana-de-açúcar colhida 
mecanicamente em áreas de reforma de canavial, sobre um Latossolo Vermelho distrófico, na Região Norte do Estado de São Paulo.

\section{MATERIAL E MÉTODOS}

O experimento foi realizado em Guariba (SP), nas coordenadas geográficas $21^{\circ}$ 22 ' 46" de latitude sul e 48 15' 02" de longitude oeste e altitude média de $618 \mathrm{~m}$. O clima é do tipo Cwa, segundo o sistema de classificação de Köppen, com verão quente e inverno seco, precipitação média anual de $1.388 \mathrm{~mm}$ e temperatura média de $21^{\circ} \mathrm{C}$.. O solo da área experimental é um Latossolo Vermelho distrófico, típico, textura argilosa, A moderado, caulinítico, hipoférrico ( $L V d)$, segundo o Sistema Brasileiro de Classificação de Solos (EMBRAPA, 2006). O solo apresentou $377 \mathrm{~g} \mathrm{~kg}^{-1}$ de argila, $38 \mathrm{~g}$ $\mathrm{kg}^{-1}$ de silte e $585 \mathrm{~g} \mathrm{~kg}^{-1}$ de areia na camada de $0-0,2 \mathrm{~m} \mathrm{e} 377,5 \mathrm{~g} \mathrm{~kg}^{-1}$ de argila, $38,5 \mathrm{~g}$ $\mathrm{kg}^{-1}$ de silte e $585 \mathrm{~g} \mathrm{~kg}^{-1}$ de areia na camada de 0,2-1,0 m de profundidade.

Os tratamentos foram realizados em área submetida à colheita de cana-deaçúcar, durante cinco cortes consecutivos, sendo apenas o primeiro corte realizado com a queima prévia da palhada, sendo os demais com colheita mecanizada. A dessecação da área submetida aos tratamentos foi realizada em 10 de novembro de 2007, utilizando-se 5,0 L ha-1 de glyphosate, quando a cana-de-açúcar variedade RB 867515 estava com 0,7 m de altura. No dia 21 de novembro de 2007, foi realizada a queima da palhada remanescente nos tratamentos com essa característica e aplicado os diferentes sistemas de preparo do solo. Para o ano agrícola 2006/2007, a dessecação foi realizada em 31 de outubro 2006, a queima da palhada foi realizada em 09 de novembro de 2006 e a aplicação dos tratamentos foi em 11 de novembro de 2006.

Os tratamentos utilizados constituíram-se de três sistemas de preparo do solo: Plantio Direto - PD, o solo foi revolvido apenas ao longo das linhas, por ocasião da semeadura, após a erradicação química da soqueira; Cultivo Mínimo - CM, foi utilizado nesse sistema, um escarificador de hastes rígidas, de arrasto, com discos de corte de palhada, cinco hastes e rolo destorroador, a uma camada de 0,20 m, após a 
erradicação química da soqueira; Plantio Convencional - PC, foi utilizado nesse sistema uma grade intermediária (24 discos), de arrasto, a uma camada de 0,15 m, por duas vezes consecutivas, uma passada do escarificador e uma passada de grade niveladora (44 discos), de arrasto, na camada de 0,10 m, após a erradicação química da soqueira. Para quantificação da palhada foi utilizado um quadro metálico de 0,25 $\mathrm{m}^{2}$ arremessado aleatoriamente em 20 pontos do experimento, determinando-se a média das quantidades de palha e extrapolada para 1,0 ha, totalizando $17 \mathrm{t} \mathrm{ha}^{-1}$ de palha no ano agrícola 2006/2007 e 15 t ha $^{-1}$ de palha no ano agrícola 2007/2008.

O delineamento experimental utilizado foi em blocos casualizados, com parcelas subsubdivididas, seis repetições, sendo que os tratamentos principais se constituíram de diferentes sistemas de preparo do solo, os secundários de dois níveis de palhada e os tratamentos ternários de duas camadas, totalizando 36 parcelas. Cada parcela experimental foi constituída por quatro linhas de 7,0 $\mathrm{m}$ de comprimento, espassadas umas das outras a 0,90 m, considerando-se como parcela útil as duas linhas centrais e descontando 1,0 m em cada extremidade das linhas, totalizando uma parcela útil de 9,0 $\mathrm{m}^{2}$. As linhas de semeadura do amendoim cruzaram-se com as linhas de plantio da cana.

No dia 23 de novembro dos dois anos agrícolas foi realizada a semeadura. Aos 115 dias após semeadura do amendoim, foram coletadas amostras de solo para a determinação da estabilidade de agregados. Em cada camada, dentro de cada parcela, coletou-se quatro amostras de solo simples, nas entrelinhas da cultura, com auxílio de um enxadão, quando a umidade do solo estava próxima da capacidade de campo, as quais foram homogeneizadas e formaram uma amostra composta, a qual foi utilizada para as determinações. No preparo das amostras, os torrões foram secos ao ar e desmanchados manualmente, tomando-se cuidado para não destruir os agregados. Para avaliar a estabilidade de agregados via úmida, foram usados $50 \mathrm{~g}$ de solo passados em peneira de $7,93 \mathrm{~mm}$ e ficaram retidos na peneira de $4,00 \mathrm{~mm}$, os quais foram pré-umedecidos, conforme o princípio de umedecimento lento descrito por KEMPER \& CHEPIL (1965). Em seguida, essa amostra foi colocada no aparelho de oscilação vertical, sobre um conjunto de peneiras de 4,00;2,00;1,00;0,50;0,25 e 0,125 
$\mathrm{mm}$ de diâmetro de abertura de malha. A superior com aberturas de 4,00 mm foi encaixada sobre outras cinco peneiras, formando um conjunto em ordem decrescente de acordo com suas respectivas aberturas, conforme descrito por YOODER (1936). Transcorridos $15 \mathrm{~min}$, as porções retidas em cada peneira foram transferidas para latas de alumínio, previamente taradas, com o auxílio de jatos de água, e secas em estufa a $105^{\circ} \mathrm{C}$, por $24 \mathrm{~h}$, para posterior pesagem. A partir dos valores dessas massas, foram calculados a porcentagem de agregados estáveis em água, o diâmetro médio geométrico (DMG) e o diâmetro médio ponderado (DMP), conforme KEMPER \& CHEPIL (1965).

Não foi descontada a areia nos cálculos do DMP, do DMG uma vez que essas partículas participam do processo de agregação do solo (CASTRO FILHO et al., 1998).

Com os dados de peso de agregados retidos em cada peneira e a umidade das amostras calculou-se a proporção de agregados estáveis em água de cada classe de tamanho (wi) em relação à massa inicial das amostras.

O Diâmetro Médio Ponderado (DMP) dos agregados foi calculado pela equação (1) conforme KEMPER \& ROSENAU (1986):

$\mathrm{DMP}=\sum_{i=1}^{n}\left(x_{i} \cdot w_{i}\right)$

Em que: wi = proporção de cada classe de agregados em relação ao total;

$x i=$ diâmetro médio de cada classe de agregados; e,

$\mathrm{n}=$ número de classes de agregados.

O Diâmetro Médio Geométrico (DMG) dos agregados foi calculado pela equação (2) conforme KEMPER \& ROSENAU (1986): 


$$
\mathrm{DMG}=\exp \left[\frac{\sum_{i=1}^{n} w i \log x i}{\sum_{i=1}^{n} w i}\right]
$$

Em que: wi = peso de agregados (g) dentro de uma classe de agregados de diâmetro médio xi.

Os dados de DMP, DMG e distribuição dos agregados nas classes de tamanho foram submetidos à análise de variância pelo Teste $\mathrm{F}$ e as médias dos tratamentos comparadas pelo teste de Tukey $(p<0,05)$.

\section{RESULTADOS E DISCUSSÃO}

Na safra 2006/2007, constatou-se interação significativa entre os sistemas de preparo do solo com os níveis de palhada, entre os sistemas de preparo com as camadas, e entre as camadas e a palhada, para a estabilidade dos agregados em água, exceto os agregados retidos na peneira com abertura de malha de 2,00 $\mathrm{mm}$ onde não houve interação entre o preparo do solo com o nível de palhada.

O diâmetro médio geométrico (DMG) e os agregados estáveis em água, exceto os agregados retidos na peneira de $2,00 \mathrm{~mm}$, diferiram em função do preparo do solo (Tabela 1). O CM e o PD proporcionaram os maiores valores de DMP, DMG e agregados $>4,00 \mathrm{~mm}$, em comparação ao PC. Por outro lado, verificou-se que o PC proporcionou os maiores valores para agregados com diâmetro $<1,00 \mathrm{~mm}$ justificados pela baixa estabilidade dos maiores agregados do solo, que durante a agitação em água se fragmentaram em agregados de menor tamanho, porém de maior resistência. A decomposição dos resíduos vegetais pode ter contribuído para a formação e estabilidade dos agregados. O aumento da estabilidade dos agregados está intimamente relacionado com a capacidade da matéria orgânica de se aderir às partículas minerais do solo, formando as ligações argilo-metal-húmicas (EDWARDS \& 
BREMNER, 1967). Muitos autores citam a importância de sistemas de manejo do solo que visam o menor tráfego de máquinas, menor revolvimento do solo e aumento do teor de carbono orgânico, como o plantio direto, o cultivo mínimo e o pousio, como medidas para recuperar as propriedades físicas do solo (CAMPOS et al., 1995; CASTRO FILHO et al., 1998; SILVA \& MIELNICZUK, 1997).

Todas as variáveis diferiram entre si para o tratamento camada do solo. O DMP que expressa a percentagem de agregados grandes retidos nas peneiras com malhas maiores e o DMG que representa o tamanho médio da classe dominante de agregados, apresentaram os maiores valores para a camada $0,00-0,10 \mathrm{~m}$ em relação a camada 0,10-0,20 m. A maior quantidade de agregados estáveis, retidos na peneira com malha de maior abertura pode estar relacionada com maiores teores de matéria orgânica do solo na camada superior, possibilitando a formação de maiores agregados do solo.

Tabela 1. Valores médios para diâmetro médio ponderado (DMP), diâmetro médio geométrico (DMG) e agregados estáveis em água por classe de tamanho, para os diferentes sistemas de preparo do solo, níveis de palhada e camadas do solo (safra 2006/2007).

\begin{tabular}{|c|c|c|c|c|c|c|c|c|}
\hline \multirow{2}{*}{ FV } & \multirow{2}{*}{ DMP } & \multirow{2}{*}{ DMG } & \multicolumn{6}{|c|}{ Agregados estáveis em áqua (mm) } \\
\hline & & & 4,00 & 2,00 & 1,00 & 0,50 & 0,25 & 0,125 \\
\hline \multirow{2}{*}{\multicolumn{9}{|c|}{ PREPARO DO SOLO }} \\
\hline & & & & & & & & \\
\hline PC & 3,12 & 2,34 & 2,51 & 0,32 & 0,14 & 0,10 & 0,04 & 0,008 \\
\hline CM & 3,56 & 2,77 & 3,55 & 0,26 & 0,10 & 0,05 & 0,02 & 0,003 \\
\hline PD & 3,73 & 2,97 & 3,23 & 0,29 & 0,11 & 0,06 & 0,03 & 0,005 \\
\hline Teste $\mathrm{F}$ & 7,19 & $6,11^{*}$ & 12,20 & $2,01^{\text {ns }}$ & 4,22 & 16,44 & $10,45^{\circ}$ & $4,41^{\circ}$ \\
\hline$C V(\%)$ & 16,41 & 23,58 & 24,11 & 23,18 & 27,57 & 46,53 & 42,95 & 39,71 \\
\hline \multicolumn{9}{|c|}{ PALHADA } \\
\hline SEM & 3,37 & 2,59 & 2,98 & 0,28 & 0,11 & 0,06 & 0,03 & 0,004 \\
\hline COM & 3,57 & 2,8 & 3,22 & 0,30 & 0,12 & 0,07 & 0,04 & 0,007 \\
\hline Teste $\mathrm{F}$ & $1,36^{\text {ns }}$ & $1,47^{\text {ns }}$ & $1,47^{\text {ns }}$ & $3,18^{\text {ns }}$ & $0,47^{\text {ns }}$ & $1,13^{\text {ns }}$ & $1,87^{\text {ns }}$ & $4,18^{\text {ns }}$ \\
\hline CV (\%) & 20,71 & 26,51 & 27,58 & 22,19 & 29,61 & 52,77 & 51,79 & 45,83 \\
\hline \multicolumn{9}{|c|}{ CAMADAS $(\mathrm{m})$} \\
\hline $0,00-0,10$ & 3,83 & 3,11 & 3,41 & 0,24 & 0,10 & 0,05 & 0,03 & 0,004 \\
\hline $0,10-0,20$ & 3,10 & 2,27 & 2,79 & 0,34 & 0,14 & 0,08 & 0,04 & 0,007 \\
\hline Teste F & 33,79 & 47,19 & 16,50 & 49,60 & 14,46 & 14,58 & 9,15 & 6,04 \\
\hline$C V(\%)$ & 15,38 & 19,27 & 20,84 & 20,55 & 24,68 & 41,32 & 40,07 & 49,64 \\
\hline
\end{tabular}

Médias seguidas pela mesma letra nas colunas não diferem entre si pelo teste de Tukey a $5 \%$ de probabilidade. ${ }^{*} \mathrm{P}<0,05 ;{ }^{\text {ns }}$ não significativo. 
Os sistemas de preparo do solo diferiram entre si para todas as variáveis analisadas para os tratamentos com palha, sendo que o PD apresentou os maiores valores de DMP, DMG e agregados $>4,00 \mathrm{~mm}$, em comparação ao PC (Tabela 2). 0 uso intensivo do solo com preparo superficial excessivo e queima de palhada proporcionaram perdas de qualidade física do solo. Solos com agregados estáveis de maior tamanho resultam em maiores valores de diâmetro médio geométrico, os quais favorecem a aeração, as trocas gasosas e a infiltração de água, em decorrência da maior macroporosidade entre os agregados, além de garantirem a microporosidade e a retenção de água dentro dos agregados (DEXTER, 1988; ANGULO et al., 1984). Juntamente com a cobertura do solo, evitam o encrostamento superficial, reduzem os riscos de enxurradas e erosão e incrementam a biologia do solo (KLADIVKO, 1994).

Para a classe de agregados com diâmetro entre 4,00 e 2,00 mm, não foi constatado interação significativa.

Para a camada $0,00-0,10$, os sistemas de preparo PD e CM proporcionaram os maiores valores de DMP, DMG e agregados $>4,00 \mathrm{~mm}$ em comparação ao PC (Tabela 3), provavelmente, devido ao constante aporte de material orgânico ao solo, o qual pode ter contribuído para aumentar a agregação do solo. Segundo DA ROS et al. (1997) após cinco anos de cultivo sob plantio direto, o diâmetro médio geométrico dos agregados foi estatisticamente equivalente ao do campo nativo, diminuindo com 0 aumento da intensidade de preparo do solo, com valores de 2,96 vezes menores no preparo convencional comparado ao campo nativo. Já, CAMPOS et al. (1995) constataram que no sistema de plantio direto o diâmetro médio geométrico dos agregados foi cerca de duas vezes maior que no sistema de plantio convencional. 
Tabela 2. Desdobramento entre os sistemas de preparo e os níveis de palhada, para os valores de diâmetro médio ponderado (DMP) e diâmetro médio geométrico (DMG) e diferentes classes de diâmetro dos agregados, para os sistemas de preparo do solo dentro dos níveis de palhada (safra 2006/2007).

\begin{tabular}{|c|c|c|c|}
\hline \multirow{2}{*}{ PALHADA } & \multicolumn{3}{|c|}{ PREPARO DO SOLO } \\
\hline & PC & $\mathrm{CM}$ & PD \\
\hline \multicolumn{4}{|c|}{$\mathrm{DMP}(\mathrm{mm})$} \\
\hline SEM & 3,33 & 3,56 & 3,81 \\
\hline COM & 2,91B & $3,55 \mathrm{AB}$ & $3,65 \mathrm{~A}$ \\
\hline \multicolumn{4}{|c|}{$\mathrm{DMG}(\mathrm{mm})$} \\
\hline SEM & 2,55 & 2,79 & 3,08 \\
\hline COM & $2,13 \mathrm{~B}$ & $2,78 \mathrm{AB}$ & $2,86 \mathrm{~A}$ \\
\hline \multicolumn{4}{|c|}{ Agregados entre 6,3 e $4,0 \mathrm{~mm}$} \\
\hline SEM & 2,76 & 3,56 & 3,35 \\
\hline COM & $2,27 \mathrm{~B}$ & $3,55 \mathrm{~A}$ & $3,12 \mathrm{~A}$ \\
\hline \multicolumn{4}{|c|}{ Agregados entre 2,0 e $1,0 \mathrm{~mm}$} \\
\hline SEM & 0,13 & 0,10 & 0,11 \\
\hline COM & $0,15 A$ & $0,10 \mathrm{~B}$ & $0,12 A B$ \\
\hline \multicolumn{4}{|c|}{ Agregados entre 1,0 e $0,5 \mathrm{~mm}$} \\
\hline SEM & $0,85 \mathrm{~A}$ & $0,05 \mathrm{~B}$ & $0,06 \mathrm{AB}$ \\
\hline COM & $0,11 \mathrm{~A}$ & $0,05 B$ & $0,06 \mathrm{~B}$ \\
\hline \multicolumn{4}{|c|}{ Agregados entre 0,5 e $0,25 \mathrm{~mm}$} \\
\hline SEM & 0,04 & 0,02 & 0,03 \\
\hline COM & $0,05 \mathrm{~A}$ & $0,02 B$ & $0,03 \mathrm{~B}$ \\
\hline \multicolumn{4}{|c|}{ Agregados entre 0,25 e $0,125 \mathrm{~mm}$} \\
\hline SEM & $0,005 b$ & 0,005 & 0,003 \\
\hline $\mathrm{COM}$ & $0,01 \mathrm{Aa}$ & $0,004 \mathrm{~B}$ & $0,006 \mathrm{AB}$ \\
\hline
\end{tabular}

O PC, pelo maior distúrbio na superfície teve um menor número de agregados grandes e um maior número de agregados < que $2,00 \mathrm{~mm}$, conseqüentemente um menor DMP. Esse sistema de manejo pode ter proporcionado a formação de agregados com menor diâmetro em relação ao PD e CM. SILVA et al. (2000a) observaram que na camada superficial, as maiores porcentagens de agregados menores que 2,00 mm foram observadas no sistema de cultivo convencional em razão dos menores teores de matéria orgânica, Fe ligado à fração orgânica, e índice de floculação. CALEGARI et al. (2006) estudando a influência de sistemas de manejo do solo, em um Latossolo Vermelho distroférrico, sobre a agregação do solo, nas camadas 0,00-0,10 e 0,10-0,20 
m, concluíram que o sistema de preparo convencional possui maior quantidade de agregados menores $(<0,25 \mathrm{~mm})$ nas duas camadas, conseqüência de uma maior pulverização do solo por meio do preparo.

Tabela 3. Desdobramento entre os sistemas de preparo do solo e as camadas de solo avaliadas, para os valores de diâmetro médio ponderado (DMP), diâmetro médio geométrico (DMG) e, para as diferentes classes de diâmetro dos agregados (safra 2006/2007).

\begin{tabular}{|c|c|c|c|}
\hline \multirow{2}{*}{ CAMADAS (m) } & \multicolumn{3}{|c|}{ PREPARO DO SOLO } \\
\hline & PC & $\mathrm{CM}$ & PD \\
\hline \multicolumn{4}{|c|}{$\mathrm{DMP}(\mathrm{mm})$} \\
\hline $0-0,10$ & $3,22 \mathrm{~B}$ & $4,15 \mathrm{Aa}$ & $4,14 \mathrm{Aa}$ \\
\hline $0,10-0,20$ & 3,03 & $2,96 b$ & $3,32 b$ \\
\hline \multicolumn{4}{|c|}{ DMG (mm) } \\
\hline $0-0,10$ & $2,42 B$ & $3,42 \mathrm{Aa}$ & $3,49 \mathrm{Aa}$ \\
\hline $0,10-0,20$ & 2,26 & $2,12 b$ & $2,44 \mathrm{~b}$ \\
\hline \multicolumn{4}{|c|}{ Agregados entre 6,30 e $4,00 \mathrm{~mm}$} \\
\hline $0-0,10$ & $2,64 \mathrm{~B}$ & $3,79 \mathrm{~A}$ & 3,79Aa \\
\hline $0,10-0,20$ & $2,28 \mathrm{~B}$ & $3,31 \mathrm{~A}$ & $2,67 \mathrm{ABb}$ \\
\hline \multicolumn{4}{|c|}{ Agregados entre 4,00 e $2,00 \mathrm{~mm}$} \\
\hline $0-0,10$ & $0,30 \mathrm{~A}$ & $0,22 \mathrm{Bb}$ & $0,20 \mathrm{Bb}$ \\
\hline $0,10-0,20$ & 0,34 & $0,31 \mathrm{a}$ & $0,37 \mathrm{a}$ \\
\hline \multicolumn{4}{|c|}{ Agregados entre 2,00 e $1,00 \mathrm{~mm}$} \\
\hline $0-0,10$ & $0,14 \mathrm{~A}$ & $0,08 \mathrm{Bb}$ & $0,08 \mathrm{Bb}$ \\
\hline $0,10-0,20$ & 0,15 & $0,11 a$ & $0,14 a$ \\
\hline \multicolumn{4}{|c|}{ Agregados entre 1,00 e $0,50 \mathrm{~mm}$} \\
\hline $0-0,10$ & $0,09 \mathrm{~A}$ & $0,04 \mathrm{~B}$ & $0,04 \mathrm{Bb}$ \\
\hline $0,10-0,20$ & $0,10 \mathrm{~A}$ & $0,06 \mathrm{~B}$ & $0,08 \mathrm{ABa}$ \\
\hline \multicolumn{4}{|c|}{ Agregados entre 0,50 e $0,25 \mathrm{~mm}$} \\
\hline $0-0,10$ & $0,04 \mathrm{~A}$ & $0,02 \mathrm{~B}$ & $0,02 \mathrm{Bb}$ \\
\hline $0,10-0,20$ & $0,05 \mathrm{~A}$ & $0,03 \mathrm{~B}$ & $0.04 \mathrm{ABa}$ \\
\hline \multicolumn{4}{|c|}{ Agregados entre 0,25 e $0,125 \mathrm{~mm}$} \\
\hline $\begin{array}{c}0-0,10 \\
010-0 ? 0\end{array}$ & $\begin{array}{c}0,007 \\
0 \text { On8A }\end{array}$ & $\begin{array}{c}0,003 \\
0,0038\end{array}$ & $0,003 b$ \\
\hline maiúsculas nas & $0,000 \pi$ & o dentro de & $\begin{array}{l}\text { núsculas nas } \\
\text { nú }\end{array}$ \\
\hline
\end{tabular}

Para a camada de 0,10-0,20 m, os agregados com diâmetro entre 6,30-4,00 mm apresentaram maiores valores no $\mathrm{CM}$ em comparação ao PC. Por conseguinte, os agregados com diâmetro menor que $1,00 \mathrm{~mm}$ apresentaram comportamento inverso 
(Tabela 3). No sistema de preparo convencional, a ruptura dos agregados ocasionada pelo revolvimento do solo contribui para um maior ataque dos organismos, acelerando as perdas de carbono orgânico pela oxidação da matéria orgânica e pelos processos de erosão (OADES, 1984; MENDONÇA \& ROWELL, 1994).

Todas as variáveis diferiram entre si no PD, entre as duas camadas avaliadas (Tabela 3). O DMP, o DMG e os agregados com diâmetro superior a $4,00 \mathrm{~mm}$ apresentaram maiores valores na camada de 0,00-0,10 m em comparação a camada 0,10-0,20 m. O sistema de preparo cultivo mínimo (CM) apresentou comportamento semelhante para o DMP e DMG. Sistemas de preparo do solo tidos como conservacionistas favorecem a formação de agregados do solo, em virtude do constante aporte de matéria orgânica ao solo, principalmente em superfície. Segundo OADES \& WATERS (1991), a matéria orgânica é o principal agente estabilizante de agregados do solo. Por outro lado, SILVA \& MIELNICZUK (1998) ao avaliarem os efeitos de sistemas de cultivo e dos atributos intrínsecos de um Latossolo Roxo e um Podzólico Vermelho-Escuro, na estabilidade de agregados, concluíram que apesar de os teores de carbono orgânico, Fe e Al, argila e grau de dispersão das argilas afetarem a agregação do solo, foram insuficientes para explicar as variações no diâmetro médio geométrico sob os diferentes sistemas de cultivo.

$\mathrm{Na}$ camada 0,00-0,10 $\mathrm{m}$ foram verificados os maiores valores de DMP e DMG em comparação a camada 0,10-0,20 m, independente dos níveis de palhada (Tabela 4). As camadas mais profundas do solo tendem a apresentar um menor teor de matéria orgânica, isto pode ocasionar uma baixa atividade biológica, conseqüentemente, causar a diminuição da resistência dos agregados sob ação da água. Esses resultados diferem dos encontrados por FONTENELE et al. (2009), que ao avaliarem o DMP, DMG e índice de estabilidade de agregados em um Latossolo Amarelo distrófico, sob quatro sistemas de manejo do solo e em quatro camadas, concluíram que no preparo convencional e plantio direto as camadas 0,00-0,05; 0,05-0,10 e 0,10-0,20 m apresentaram menores valores para estes índices com relação a camada 0,02-0,04 m, justificados pelo pouco tempo de adoção desses sistemas de manejo, os quais ainda não manifestaram melhorias significativas no estado de agregação do solo. 
Tabela 4. Valores médios para diâmetro médio ponderado (DMP), diâmetro médio geométrico (DMG) e, para as diferentes classes de diâmetro dos agregados, para os níveis de palhada e as camadas amostradas (safra 2006/2007).

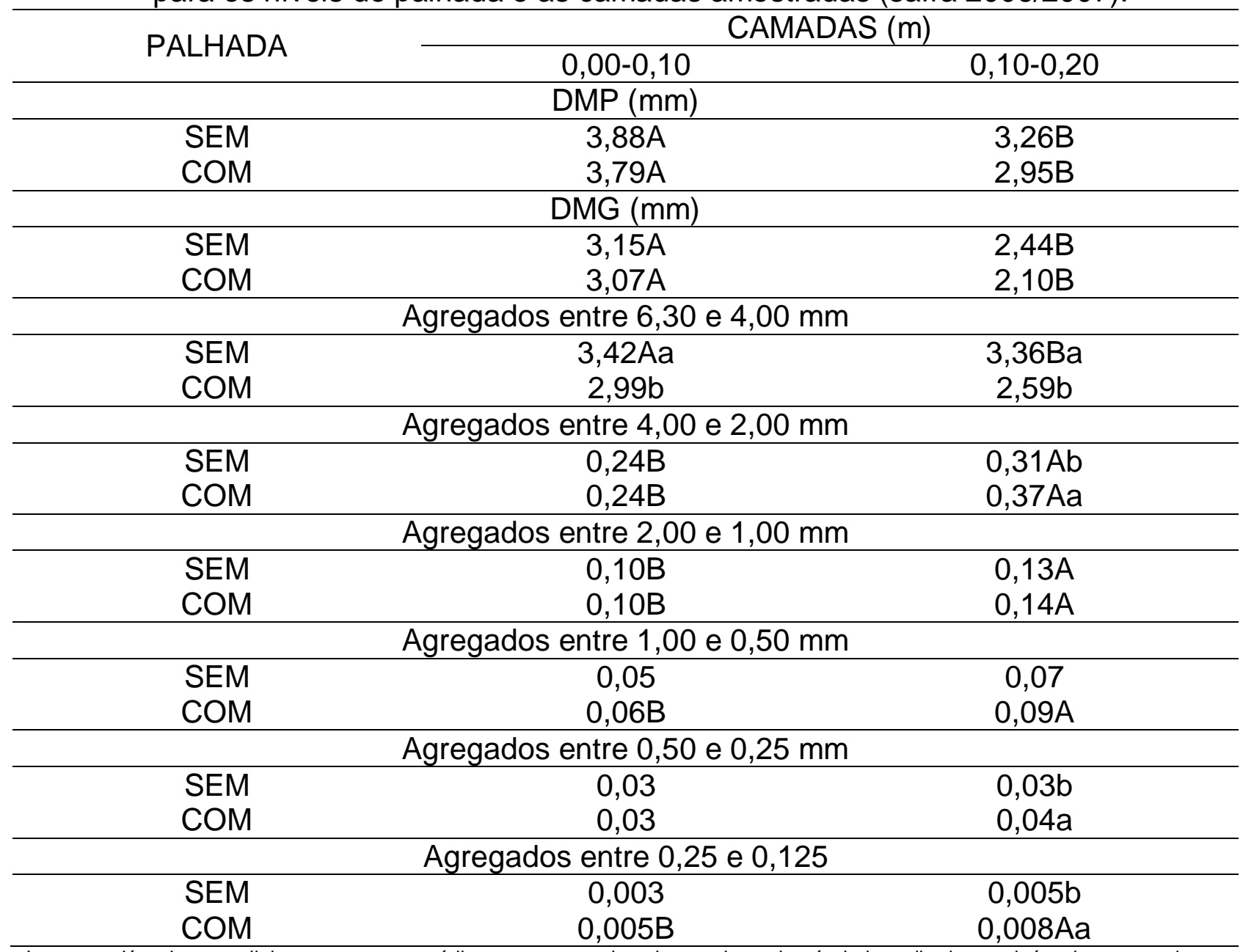

Letras maiúsculas nas linhas comparam médias entre camadas dentro de cada nível de palhada e minúsculas nas colunas comparam médias entre os níveis de palhada. Letras distintas indicam diferenças significativas a $5 \%$ de probabilidade, pelo teste de Tukey.

Agregados com diâmetro $>4,00 \mathrm{~mm}$ diferiram entre os níveis de palhada, para as duas camadas do solo, sendo verificados os maiores valores nos tratamentos sem palha. Teoricamente, a ausência de resíduos vegetais sobre a superfície do solo resulta em diminuição dos agregados estáveis, entretanto, neste estudo verificou-se que a ausência de cobertura vegetal proporcionou o aumento da agregação do solo, provavelmente em função do adensamento superficial do solo, o qual pode ser atribuído ao tráfego de máquinas e implementos agrícolas. O maior ou menor grau de 
compactação oriundo das operações agrícolas depende da presença de resíduos culturais e da estrutura do solo (SIDIRAS et al., 1984).

Para a safra 2007/2008, houve interação significativa entre os sistemas de preparo do solo e os níveis de palhada, entre os sistemas de preparo e as camadas de solo e, entre as camadas e a palhada, para a estabilidade dos agregados em água, exceto os agregados retidos na peneira com abertura de malha de 0,25 $\mathrm{mm}$ onde não houve interação entre o preparo do solo com o nível de palhada e com as camadas do solo (Tabela 5).

Tabela 5. Valores médios para diâmetro médio ponderado (DMP), diâmetro médio geométrico (DMG) e agregados estáveis em água por classe de tamanho, para os diferentes sistemas de preparo do solo, níveis de palhada e camadas do solo (safra 2007/2008).

\begin{tabular}{|c|c|c|c|c|c|c|c|c|}
\hline \multirow[b]{2}{*}{ FV } & \multirow{2}{*}{ DMP } & \multirow{2}{*}{ DMG } & \multicolumn{6}{|c|}{ Agregados estáveis em água (mm) } \\
\hline & & & 4,00 & 2,00 & 1,00 & 0,50 & 0,25 & 0,125 \\
\hline & \multicolumn{8}{|c|}{ 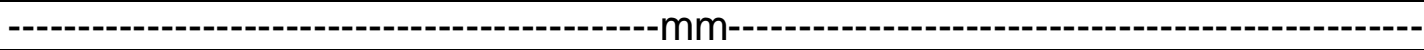 } \\
\hline \multicolumn{9}{|c|}{ PREPARO DO SOLO } \\
\hline PC & 3,04 & 2,17 & 2,30 & 0,31 & 0,12 & 0,07 & 0,03 & 0,007 \\
\hline CM & 3,43 & 2,53 & 2,80 & 0,37 & 0,15 & 0,07 & 0,03 & 0,008 \\
\hline PD & 3,55 & 2,76 & 3,02 & 0,39 & 0,17 & 0,09 & 0,04 & 0,010 \\
\hline Teste F & $2,58^{\text {ns }}$ & $2,43^{\text {ns }}$ & $3,00^{\mathrm{ns}}$ & $2,33^{\text {ns }}$ & $3,64^{\mathrm{ns}}$ & $3,04^{\mathrm{ns}}$ & $3,12^{\text {ns }}$ & $2,83^{* *}$ \\
\hline $\mathrm{CV}(\%)$ & 24,23 & 27,38 & 28,22 & 27,83 & 31,42 & 40,68 & 50,65 & 52,75 \\
\hline \multicolumn{9}{|c|}{ PALHADA } \\
\hline SEM & 3,26 & 2,38 & 2,59 & 0,36 & 0,15 & 0,08 & 0,04 & 0,009 \\
\hline COM & 3,42 & 2,58 & 2,82 & 0,35 & 0,14 & 0,07 & 0,03 & 0,007 \\
\hline Teste F & $2,89^{\text {ns }}$ & $5,14^{*}$ & $3,72^{\text {ns }}$ & $0,38^{\text {ns }}$ & $4,81^{*}$ & $2,09^{\text {ns }}$ & $0,75^{\mathrm{ns}}$ & $15,00^{* *}$ \\
\hline CV (\%) & 11,81 & 14,69 & 18,70 & 26,47 & 23,51 & 36,63 & 45,43 & 22,66 \\
\hline \multicolumn{9}{|c|}{ CAMADAS $(\mathrm{m})$} \\
\hline $0-0,10$ & 3,40 & 2,57 & 2,79 & 0,33 & 0,14 & 0,08 & 0,04 & 0,008 \\
\hline $0,10-0,2$ & 3,28 & 2,40 & 2,62 & 0,39 & 0,15 & 0,08 & 0,04 & 0,009 \\
\hline Teste F & $1,70^{\text {ns }}$ & $4,51^{*}$ & $2,36^{\mathrm{ns}}$ & $10,19^{* *}$ & $3,29^{\text {ns }}$ & $0,03^{n s}$ & $0,00^{\text {ns }}$ & $3,33 n s$ \\
\hline $\mathrm{CV}(\%)$ & 11,52 & 14,08 & 17,02 & 22,09 & 22,11 & 27,13 & 31,48 & 32,05 \\
\hline
\end{tabular}

Médias seguidas pela mesma letra nas colunas não diferem entre si pelo teste de Tukey a 5\% de probabilidade. PC: plantio convencional, CM: cultivo mínimo e, PD: plantio direto. * $\mathrm{P}<0,05 ;{ }^{\text {ns }}$ não significativo.

O DMG diferiu entre os níveis de palhada e entre as camadas do solo, sendo que os maiores valores foram verificados para os tratamentos com palha remanescente em comparação aos tratamentos sem palha e na camada 0,00-0,10 m com relação a 
camada 0,10-0,20 m (Tabela 5). O aporte de matéria orgânica na superfície do solo via sistema radicular, pode ter sido fundamental para a formação e estabilidade dos macroagregados do solo. As raízes das plantas proporcionam a formação de agregados do solo pela liberação de exsudatos, que são agentes cimentantes (MIELNICZUK, 1999), ou durante seu crescimento, o qual aproxima as partículas e as mantém fortemente unidas pelas forças de coesão geradas durante a absorção de água (ZONTA et al., 2006).

Para os tratamentos com palhada remanescente, os sistemas de preparo PC e PD não diferiram entre si e proporcionaram maiores valores de DMP, DMG e agregados $>$ 4,00 mm em comparação ao sistema de preparo CM (Tabela 6). A rotação de culturas entre gramíneas e leguminosas (cana-de-açúcar x amendoim) proporciona uma grande diversidade de resíduos vegetais além da ampla exploração do solo pelos diferentes sistemas radiculares das culturas utilizadas, isso pode favorecer a agregação do solo. A sucessão de gramíneas com leguminosas proporciona a maior agregação do solo, devido ao sistema radicular das gramíneas e à taxa de decomposição das leguminosas (CAMPOS et al., 1999; WOHLENBERG et al., 2004). Outros autores relataram maior formação e estabilidade de agregados em solos cultivados com gramíneas à leguminosas, devido à alta densidade de raízes, às periódicas renovações do sistema radicular e à uniforme distribuição dos exsudatos no solo, que estimulam a atividade microbiana, cujos subprodutos atuam na formação e estabilização dos agregados (SILVA \& MIELNICZUK, 1997).

No sistema de preparo do solo PD verificaram-se maiores valores de DMP, DMG e agregados $>4,00 \mathrm{~mm}$, sob palhada remanescente em relação ao solo sem palha. Alguns autores indicam que os sistemas conservacionistas que mantêm parcial ou totalmente os resíduos na superfície do solo, tais como o plantio direto e o cultivo mínimo, contribuem para a melhoria da estrutura do solo (CARPENEDO \& MIELNICZUK, 1990; CASTRO FILHO et al., 1998). Por outro lado, ROTH et al. (1991) constataram que manejos que mantêm o solo descoberto diminuem a estabilidade de agregados, causando selamento superficial, reduzindo a infiltração de água e, conseqüentemente, induzindo à enxurrada e à erosão. Os resíduos vegetais além de 
acarretarem maior aporte de carbono também influenciam as propriedades do solo, uma vez que atuam como isolante entre o solo e a atmosfera (WENDLING et al., 2005). Solos com uma boa cobertura impedem ou diminuem a ação direta das gotas de chuva, mantêm mais uniforme a umidade e temperatura, favorecem o desenvolvimento do sistema radicular e atividade microbiana e contribuem para a criação de um ambiente mais favorável à agregação (CAMPOS et al., 1999).

Para as classes de agregados com diâmetro entre 4,00 - 2,00 e 0,50-0,25 mm, não foi constatado interação significativa para os preparos do solo e os níveis de palhada.

Tabela 6. Valores médios para diâmetro médio ponderado (DMP), diâmetro médio geométrico (DMG), e diferentes classes de diâmetro dos agregados do solo, para os sistemas de preparo do solo dentro dos níveis de palhada (safra 2007/2008).

\begin{tabular}{|c|c|c|c|}
\hline \multirow{2}{*}{ PALHADA } & \multicolumn{3}{|c|}{ PREPARO DO SOLO } \\
\hline & PC & $\mathrm{CM}$ & PD \\
\hline \multicolumn{4}{|c|}{ DMP (mm) } \\
\hline SEM & 3,40 & 3,17 & $3,21 b$ \\
\hline COM & $3,70 \mathrm{~A}$ & $2,91 \mathrm{~B}$ & $3,64 \mathrm{Aa}$ \\
\hline \multicolumn{4}{|c|}{$\mathrm{DMG}(\mathrm{mm})$} \\
\hline SEM & $2,60 b$ & 2,28 & $2,29 b$ \\
\hline COM & $2,92 \mathrm{Aa}$ & $2,06 \mathrm{~B}$ & $2,77 \mathrm{ABa}$ \\
\hline \multicolumn{4}{|c|}{ Agregados entre 6,30 e $4,00 \mathrm{~mm}$} \\
\hline SEM & 2,83 & 2,43 & $2,52 b$ \\
\hline COM & $3,12 \mathrm{~A}$ & $2,18 \mathrm{~B}$ & $3,07 \mathrm{Aa}$ \\
\hline \multicolumn{4}{|c|}{ Agregados entre 2,00 e $1,00 \mathrm{~mm}$} \\
\hline SEM & 0,13 & 0,16 & $0,16 a$ \\
\hline COM & $0,11 \mathrm{~B}$ & $0,17 \mathrm{~A}$ & $0,13 \mathrm{ABb}$ \\
\hline \multicolumn{4}{|c|}{ Agregados entre 1,00 e $0,50 \mathrm{~mm}$} \\
\hline SEM & 0,07 & 0,08 & 0,09 \\
\hline COM & $0,06 \mathrm{~B}$ & $0,10 \mathrm{~A}$ & $0,06 \mathrm{~B}$ \\
\hline \multicolumn{4}{|c|}{ Agregados entre 0,25 e $0,125 \mathrm{~mm}$} \\
\hline SEM & 0,007 & 0,01 & $0,01 a$ \\
\hline COM & $0,007 \mathrm{AB}$ & $0,01 \mathrm{~A}$ & $0,005 \mathrm{Bb}$ \\
\hline
\end{tabular}

Letras maiúsculas nas linhas comparam médias entre preparos do solo dentro de cada nível de palhada e minúsculas nas colunas comparam médias entre os níveis de palhada. Letras distintas indicam diferenças significativas a $5 \%$ de probabilidade, pelo teste de Tukey. PC: plantio convencional, CM: cultivo mínimo e, PD: plantio direto. 
Para a camada de 0,00-0,10 $\mathrm{m}$, foram verificadas diferenças entre os tratamentos apenas para os agregados com diâmetro menor que 2,00 mm, sendo que o CM proporcionou maiores valores de agregação em comparação ao PC (Tabela 7). A estabilidade dos agregados está associada ao aporte de $C$ via produção de matéria seca pela cultura da cana-de-açúcar (HAYNES \& BEARE, 1997) e à presença de $C$ no solo, o qual é um importante constituinte dos agentes cimentantes (BLAIR et al., 2005), bem como favorece a maior atividade biológica no solo (BRONICK \& LAL, 2005).

Tabela 7. Valores médios para diâmetro médio ponderado (DMP), diâmetro médio geométrico (DMG) e diferentes classes de diâmetro dos agregados, para os diferentes sistemas de preparo do solo em função de suas camadas amostradas (safra 2007/2008).

\begin{tabular}{|c|c|c|c|}
\hline \multirow{2}{*}{ CAMADAS (m) } & \multicolumn{3}{|c|}{ PREPARO DO SOLO } \\
\hline & PC & $\mathrm{CM}$ & PD \\
\hline \multicolumn{4}{|c|}{$\mathrm{DMP}(\mathrm{mm})$} \\
\hline $0-0,10$ & 3,56 & 3,04 & $3,60 a$ \\
\hline $0,10-0,20$ & 3,54 & 3,05 & $3,25 b$ \\
\hline \multicolumn{4}{|c|}{$\mathrm{DMG}(\mathrm{mm})$} \\
\hline $0-0,10$ & 2,80 & 2,16 & $2,76 a$ \\
\hline $0,10-0,20$ & 2,72 & 2,18 & $2,30 b$ \\
\hline \multicolumn{4}{|c|}{ Agregados entre 6,30 e $4,00 \mathrm{~mm}$} \\
\hline $0-0,10$ & 3,06 & 2,26 & $3,05 a$ \\
\hline $0,10-0,20$ & 2,98 & 2,35 & $2,54 b$ \\
\hline \multicolumn{4}{|c|}{ Agregados entre 4,00 e $2,00 \mathrm{~mm}$} \\
\hline $0-0,10$ & 0,28 & 0,37 & $0,33 b$ \\
\hline $0,10-0,20$ & 0,34 & 0,41 & $0,41 \mathrm{a}$ \\
\hline \multicolumn{4}{|c|}{ Agregados entre 2,00 e 1,00 mm } \\
\hline $0-0,10$ & $0,12 \mathrm{~B}$ & $0,17 \mathrm{~A}$ & $0,12 \mathrm{ABb}$ \\
\hline $0,10-0,20$ & $0,12 \mathrm{~B}$ & $0,16 \mathrm{~A}$ & $0,17 \mathrm{Aa}$ \\
\hline \multicolumn{4}{|c|}{ Agregados entre 1,00 e $0,05 \mathrm{~mm}$} \\
\hline $0-0,10$ & $0,07 \mathrm{~B}$ & $0,1 \mathrm{~A}$ & $0,07 \mathrm{~B}$ \\
\hline $0,10-0,20$ & 0,06 & 0,09 & 0,08 \\
\hline \multicolumn{4}{|c|}{ Agregados entre 0,25 e $0,125 \mathrm{~mm}$} \\
\hline $0-0,10$ & $0,007 \mathrm{~B}$ & $0,01 \mathrm{~A}$ & $0,006 \mathrm{Bb}$ \\
\hline $0,10-0,20$ & 0,007 & 0,01 & $0,009 a$ \\
\hline
\end{tabular}


Para a camada de 0,10-0,20 m, verificou-se que o PD e CM apresentaram maiores valores de agregados com diâmetro entre 2,00 e 1,00 mm com relação ao PC (Tabela 7). Provavelmente, o intenso revolvimento do solo esteja causando a degradação de sua estrutura.

Entre a camada de 0-0,10 e 0,10-0,20 m, apenas o PD proporcionou diferenças na agregação do solo (Tabela 7). Com exceção dos agregados com diâmetro entre 1,00 e $0,50 \mathrm{~mm}$, todos os demais diferiram entre si para as duas camadas de solo, sendo que, a camada 0,00-0,10 m apresentou maiores valores para DMP, DMG e agregados $>$ 4,0 mm, em comparação a camada 0,10-0,20 m. Para as demais variáveis verificouse comportamento inverso. O sistema de plantio direto mantém o solo protegido contra a ação das intempéries climáticas e esse constante aporte de resíduos pode ser responsável pelo aumento na agregação do solo. CASTRO FILHO et al. (1998) avaliando um Latossolo Roxo concluíram que o acúmulo de resíduos vegetais na superfície do solo, como conseqüência da adoção do sistema de plantio direto, melhorou o estado de agregação graças ao incremento do teor de carbono orgânico, sobretudo na camada de 0,00-10 cm. Esses autores concluíram ainda que os valores de DMG dos agregados sob sistema de plantio direto foram significativamente superiores em relação aos do plantio convencional.

As variáveis diferiram entre si na camada 0,00-0,10 m em função dos níveis de palhada, exceto os valores de agregados retidos na peneira de abertura de malha de 2,00 $\mathrm{mm}$ (Tabela 8). Os maiores valores de DMG e agregados $>4,00 \mathrm{~mm}$ foram verificados para os tratamentos com palhada remanescente em comparação aos tratamentos sem palhada. Os maiores valores encontrados para agregados $>4,00 \mathrm{~m}$ na camada 0,00-0,1 m sob palhada, em relação aos tratamentos sem palhada e a camada 0,10-0,20 m, indica a maior quantidade de agregados com maior diâmetro, conseqüentemente, as classes inferiores de agregados tendem a apresentar comportamento inverso, atribuídos à menor estabilidade dos agregados sob tratamento sem palha. Provavelmente o contínuo aporte de resíduos na superfície do solo tenha contribuído para os maiores valores de agregação. O sistema plantio direto, ao manter os resíduos vegetais na superfície, tende a aumentar os teores de matéria orgânica do 
solo, melhorando a agregação das partículas em relação ao preparo convencional (CARPENEDO \& MIELNICZUK, 1990).

Tabela 8. Valores médios para diâmetro médio ponderado (DMP), diâmetro médio geométrico (DMG) e diferentes classes de diâmetro de agregados, para os níveis de palhada e as camadas amostradas (safra 2007/2008).

\begin{tabular}{|c|c|c|}
\hline \multirow{2}{*}{ PALHADA } & \multicolumn{2}{|c|}{ CAMADA $(m)$} \\
\hline & $0,00-0,10$ & $0,10-0,20$ \\
\hline \multicolumn{3}{|c|}{$\mathrm{DMP}(\mathrm{mm})$} \\
\hline SEM & $3,16 \mathrm{~B}$ & 3,64Aa \\
\hline COM & 3,62 & $3,20 \mathrm{~b}$ \\
\hline \multicolumn{3}{|c|}{$\mathrm{DMG}(\mathrm{mm})$} \\
\hline SEM & $2,31 b$ & 2,47 \\
\hline COM & $2,84 \mathrm{Aa}$ & $2,32 \mathrm{~B}$ \\
\hline \multicolumn{3}{|c|}{ Agregados entre 6,30 e $4,00 \mathrm{~mm}$} \\
\hline SEM & $2,47 b$ & 2,72 \\
\hline COM & $3,11 \mathrm{Aa}$ & $2,53 \mathrm{~B}$ \\
\hline \multicolumn{3}{|c|}{ Agregados entre 4,00 e $2,00 \mathrm{~mm}$} \\
\hline SEM & 0,34 & $0,31 b$ \\
\hline COM & 0,38 & $0,39 a$ \\
\hline \multicolumn{3}{|c|}{ Agregados entre 2,00 e $1,00 \mathrm{~mm}$} \\
\hline SEM & $0,16 a$ & 0,15 \\
\hline COM & $0,12 \mathrm{Bb}$ & $0,15 A$ \\
\hline \multicolumn{3}{|c|}{ Agregados entre 1,00 e $0,50 \mathrm{~mm}$} \\
\hline SEM & $0,09 \mathrm{Aa}$ & $0,07 \mathrm{~B}$ \\
\hline COM & $0,07 \mathrm{Bb}$ & $0,08 \mathrm{~A}$ \\
\hline \multicolumn{3}{|c|}{ Agregados entre 0,50 e $0,25 \mathrm{~mm}$} \\
\hline SEM & 0,04Aa & $0,04 \mathrm{~B}$ \\
\hline COM & $0,03 \mathrm{Bb}$ & $0,03 \mathrm{~A}$ \\
\hline \multicolumn{3}{|c|}{ Agregados entre 0,25 e $0,125 \mathrm{~mm}$} \\
\hline $\begin{array}{l}\text { SEM } \\
\text { COM }\end{array}$ & $\begin{array}{c}0,009 \mathrm{a} \\
0,006 \mathrm{Bb}\end{array}$ & $\begin{array}{c}0,008 \\
0,009 \mathrm{~A}\end{array}$ \\
\hline
\end{tabular}

Letras maiúsculas nas linhas comparam médias entre camadas dentro de cada nível de palhada e minúsculas nas colunas comparam médias entre os níveis de palhada. Letras distintas indicam diferenças significativas a $5 \%$ de probabilidade, pelo teste de Tukey. 


\section{CONCLUSÕES}

Para a safra 2006/2007 o PD e o CM proporcionaram maior agregação do solo com relação ao $\mathrm{PC}$, nas duas camadas avaliadas. A ausência de palha promoveu maiores quantidades de agregados com diâmetro entre 6,30 e 4,00 mm, em comparação à palhada.

Na safra 2007/2008 a palhada proporcionou maior diâmetro médio geométrico (DMG) ao solo, em comparação à ausência de palhada, no plantio convencional e no plantio direto. E proporcionou também, maior DMG e maior quantidade de agregados com diâmetro entre 6,30 e 4,00 mm, na camada 0-0,10 m, em comparação à ausência de palhada. 


\section{CAPITULO 3 - INFLUÊNCIA DO SISTEMA DE PREPARO DO SOLO EM ÁREA DE REFORMA DE CANAVIAL NOS ATRIBUTOS FÍSICOS E CRESCIMENTO RADICULAR DO AMENDOIM}

RESUMO: Com a finalidade de eliminar as queimadas e a mobilização superficial do solo a colheita mecanizada de cana-de-açúcar está cada vez mais presente no sistema de produção brasileiro. Assim, o objetivo deste trabalho foi avaliar diferentes sistemas de preparo do solo: Plantio Convencional (PC), Cultivo Mínimo (CM) e Plantio Direto (PD), com dois níveis de palhada remanescente da cana-de-açúcar colhida mecanicamente, nos atributos físicos do solo e crescimento radicular do amendoim em três camadas. No dia 23 de novembro de 2007 foi semeado o amendoim, cultivar Runner IAC 886 em um Latossolo Vermelho distrófico no município de Guariba (SP). O delineamento experimental utilizado foi em blocos casualizados, com parcelas subsubdivididas e seis repetições. Os tratamentos constituíram de três diferentes sistemas de preparo do solo, dois níveis de palhada (sem e com) e três profundidades de coleta (amostras indeformadas de solo nas camadas de 0,03-0,06; 0,13-0,16 e 0,230,26 m) para a determinação da resistência mecânica do solo à penetração, densidade, porosidade e duas profundidades $(0-0,1$ e 0,1-0,2 m) para a determinação do comprimento radicular, superfície radicular, diâmetro radicular e massa seca das raízes. A maior mobilização do solo ocasionado pela escarificação e gradagens, reduziu a compactação na camada mais superficial em comparação aos demais sistemas de preparo. Os maiores valores de densidade do solo e resistência mecânica do solo à penetração encontrados na camada mais superficial do PD aumentou o diâmetro radicular e reduziram o comprimento radicular, a massa seca das raízes e superfície radicular.

Palavras Chave: Plantio direto, desenvolvimento radicular, palhada de cana-de-açúcar, Arachis hypogaea L. 


\section{INTRODUÇÃO}

Nos últimos anos as áreas cultivadas com cana-de-açúcar têm se expandido consideravelmente, sendo o Brasil o maior produtor mundial desta cultura. Por sua vez, o cultivo do amendoim no País ocupa aproximadamente 115 mil ha e cerca de $77 \%$ da produção nacional se concentra no estado de São Paulo (AGRIANUAL, 2009). Essa produção advém principalmente das áreas de reforma de canaviais, nas quais o amendoim é uma alternativa viável a ser utilizada na sucessão com a cana-de-açúcar (BOLONHEZl et al., 2005). Dentre os benefícios do uso do amendoim nas áreas de reforma de canavial, destaca-se a redução do custo de implantação do canavial (ORTOLAN, 1979), aumento da produtividade de colmos (ALEONI \& BEAUCLAIR, 1995), boa fixação biológica de nitrogênio (BORGES et al., 2007), diminuição na população de nematóides que ocorrem na cana-de-açúcar (MOURA et al., 1997), conservação do solo devido à cobertura do solo numa época de alta precipitação pluvial (VOLK et al., 2004), ciclagem de nutrientes (FEITOSA et al., 1993) e redução da incidência de plantas daninhas durante o ciclo da cana-de-açúcar (LORENZI, 1983).

O cultivo da cana-de-açúcar envolve o uso intenso de máquinas agrícolas em todas as etapas, desde o preparo do solo até a colheita. A pressão exercida pelo tráfego intenso e acumulativo das colhedoras de corte de cana crua, veículos de transbordo e implementos de cultivo ao longo dos anos em condições de umidade inadequada podem causar a compactação do solo (SOUZA et al., 2005).

A compactação do solo reduz a absorção de água e nutrientes pelas plantas por interferir na aeração do solo, diminuindo a disponibilidade de oxigênio e, em conseqüência, influenciando na intensidade do processo de respiração, já que a absorção de nutrientes pelas raízes é um processo ativo que consome energia (EPSTEN, 1975), resultando, em última instância, no declínio da produtividade das culturas (BEUTLER et al., 2005; LEONEL et al., 2007a).

O cultivo dependendo da intensidade de preparo, acarreta modificações nos atributos físicos que são evidenciados pela diminuição do volume dos macroporos, do tamanho de agregados, da taxa de infiltração de água, aumento da resistência à 
penetração de raízes e da densidade do solo (SECCO et al., 2004; STONE \& SILVEIRA, 2001). O crescimento de raízes e a produção das culturas são influenciados pelo manejo utilizado (SILVA et al., 2000b), pelo grau de compactação do solo (BEUTLER \& CENTURION, 2004) e pelo cultivo anterior (SILVA \& ROSOLEM, 2002).

Assim, o presente trabalho teve como objetivo avaliar, em condições de campo, os atributos físicos do solo e o crescimento do sistema radicular do amendoim cultivado em um Latossolo Vermelho submetido a diferentes sistemas de preparo do solo e dois níveis de palhada remanescente da cana-de-açúcar colhida mecanicamente.

\section{MATERIAL E MÉTODOS}

O experimento foi realizado em Guariba (SP), nas coordenadas geográficas $21^{\circ}$

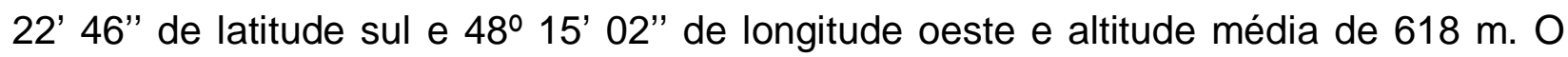
clima é do tipo Cwa, segundo o sistema de classificação de Köppen, com verão quente e inverno seco, precipitação média anual de $1.388 \mathrm{~mm}$ e temperatura média de $21^{\circ} \mathrm{C}$. As precipitações pluviais durante o ciclo da cultura estão apresentadas na Figura 1. 0 solo da área experimental é um Latossolo Vermelho distrófico, típico, textura argilosa, A moderado, caulinítico, hipoférrico ( $(\mathrm{VV} d)$, segundo o Sistema Brasileiro de Classificação de Solos (EMBRAPA, 2006). O solo apresentou $377 \mathrm{~g} \mathrm{~kg}^{-1}$ de argila, $38 \mathrm{~g} \mathrm{~kg}^{-1}$ de silte e $585 \mathrm{~g} \mathrm{~kg}^{-1}$ de areia na camada de 0-0,2 m e $377,5 \mathrm{~g} \mathrm{~kg}^{-1}$ de argila, $38,5 \mathrm{~g} \mathrm{~kg}^{-1}$ de silte e $585 \mathrm{~g} \mathrm{~kg}^{-1}$ de areia na camada de 0,2-1,0 m de profundidade.

Os tratamentos foram realizados em área submetida à colheita de cana-deaçúcar, durante cinco cortes consecutivos, sendo apenas o primeiro corte realizado com a queima prévia da palhada, e os demais com colheita mecanizada. A dessecação da área submetida aos tratamentos foi realizada em 10 de novembro de 2007, utilizandose $2.400 \mathrm{~g}$ de i.a. por ha-1 de glyphosate, quando a cana-de-açúcar variedade RB 86 7515 estava com $0,7 \mathrm{~m}$ de altura. No dia 21 de novembro de 2007, foi realizada a queima da palhada remanescente nos tratamentos com essa característica e aplicado os diferentes sistemas de preparo do solo. 
Os tratamentos utilizados constituíram-se de três sistemas de preparo do solo: Plantio Direto - PD (o solo foi revolvido apenas ao longo das linhas, por ocasião da semeadura, após a erradicação química da soqueira); Cultivo Mínimo - CM (foi utilizado nesse sistema, um escarificador de hastes rígidas, marca Baldan, modelo ASDADR $05 \mathrm{H}$, de arrasto, com discos de corte de palhada, cinco hastes e rolo destorroador, a uma profundidade de $0,20 \mathrm{~m}$, após a erradicação química da soqueira); Plantio Convencional - PC (foi utilizado nesse sistema uma grade intermediária, marca Marchesan Tatu, modelo GAICR (24 discos), de arrasto, a uma profundidade de 0,15 m, por duas vezes consecutivas, uma passada do escarificador e uma passada de grade niveladora, marca Super Tatu, modelo GNF (44 discos), de arrasto, na profundidade de 0,10 m, após a erradicação química da soqueira. Para quantificação da palhada foi utilizado um quadro metálico de $0,25 \mathrm{~m}^{2}$ arremessado aleatoriamente em 20 pontos do experimento, determinada a média das quantidades de palha e extrapolada para 1,0 ha, totalizando $15 \mathrm{t} \mathrm{ha}^{-1}$ de palha remanescente.

O delineamento experimental utilizado foi em blocos casualizados, com parcelas subsubdivididas, seis repetições, sendo que os tratamentos principais se constituíram de diferentes sistemas de preparo do solo, os secundários de dois níveis de palhada e os tratamentos ternários de três profundidades para os atributos físicos do solo e duas profundidades para o crescimento do sistema radicular, totalizando 36 unidades experimentais de 7,0 $\mathrm{m} \times 3,6 \mathrm{~m}$.

O solo foi analisado quimicamente antes da instalação do experimento, segundo metodologia citada por RAlJ et al. (1987), na camada de 0-0,2 m, que revelou os seguintes resultados: $21 \mathrm{~g} \mathrm{dm}^{-3}$ de matéria orgânica; 5,2 de $\mathrm{pH}\left(\mathrm{CaCl}_{2}\right) ; 17 \mathrm{mg} \mathrm{dm}^{-3}$ de $\mathrm{P}$ (resina); 1,8 $\mathrm{mmol}_{\mathrm{c}} \mathrm{dm}^{-3}$ de $\mathrm{K}^{+} ; 24 \mathrm{mmol}_{\mathrm{c}} \mathrm{dm}^{-3}$ de $\mathrm{Ca}^{2+} ; 14 \mathrm{mmol}_{\mathrm{c}} \mathrm{dm}^{-3} \mathrm{de} \mathrm{Mg}^{2+} ; 25$ $\mathrm{mmol}_{\mathrm{c}} \mathrm{dm}^{-3}$ de $\mathrm{H}+\mathrm{Al}$; SB de $39,8 \mathrm{mmol}_{\mathrm{c}} \mathrm{dm}^{-3}$; CTC de $64,8 \mathrm{mmol}_{\mathrm{c}} \mathrm{dm}^{-3}$ e saturação por bases de $61 \%$. O solo foi adubado com $0,3 \mathrm{t} \mathrm{ha}^{-1}$ do adubo formulado 02-20-20, para a obtenção da produtividade esperada de amendoim de $3 \mathrm{t} \mathrm{ha}^{-1}$, segundo RAIJ et al. (1997). No dia 23 de novembro de 2007 foi semeado o amendoim, cultivar Runner IAC 886, no espaçamento de 0,9 m entrelinhas, distribuindo-se 30 sementes por metro e, após 15 dias, foi realizado o desbaste, ajustando-se a densidade para 15 plantas por 
metro. A parcela experimental foi constituída por quatro linhas de $7,0 \mathrm{~m}$ de comprimento, considerando-se como parcela útil as duas linhas centrais e descontando 1,0 m em cada extremidade das linhas, totalizando uma parcela útil de $9,0 \mathrm{~m}^{2}$.

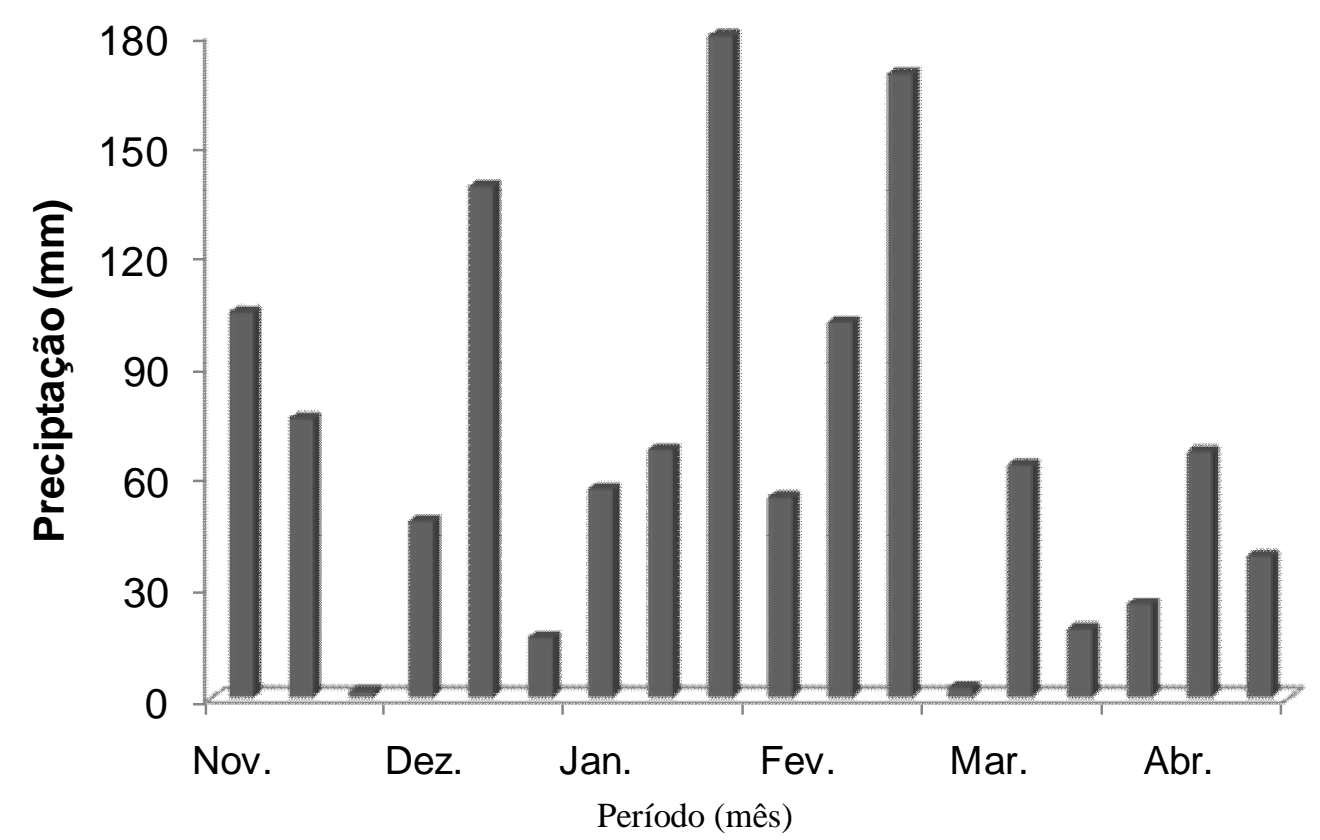

Figura 1. Precipitação pluvial a cada dez dias no período de 01 de novembro de 2007 a 30 de abril de 2008.

Foram coletadas amostras indeformadas de solo, na entrelinha da cultura, com cilindros de $52,9610^{-6} \mathrm{~m}^{3}$ (0,03 $\mathrm{m}$ de altura e $0,048 \mathrm{~m}$ de diâmetro), nas camadas de 0,03-0,06; 0,13-0,16 e 0,23-0,26 m, para determinações dos atributos físicos. A microporosidade foi determinada na tensão de 0,01 MPa, em câmaras de pressão de Richards com placa porosa (KLUTE, 1986); a porosidade total, segundo DANIELSON \& SUTHERLAND (1986), e a macroporosidade, obtida por diferença entre a porosidade total e a microporosidade. A resistência mecânica do solo à penetração (RP) foi determinada com o solo com conteúdo de água retida na tensão de $0,01 \mathrm{MPa}$, com duas repetições por amostra, na camada de 0,01 a $0,02 \mathrm{~m}$ no cilindro. A RP foi determinada com o penetrômetro eletrônico estático, com velocidade constante de penetração de $0,01 \mathrm{~m} \mathrm{~min}^{-1}$, cone com ângulo de $30^{\circ}$ e com área da base de 2,96 x 10 $0^{-6}$ 
$\mathrm{m}^{2}$, equipado com atuador linear e célula de carga de $20 \mathrm{~kg}$, acoplada a um microcomputador para a aquisição dos dados, conforme descrito por TORMENA et al. (1998). Na seqüência, as amostras foram secas em estufa a $105^{\circ} \mathrm{C}$, durante 24 horas, para a determinação da densidade do solo (BLAKE \& HARTGE, 1986).

Aos 77 dias após semeadura, na fase reprodutiva de formação das vagens da cultura do amendoim, período no qual, segundo GREGORY \& REDDY (1982), o sistema radicular reduz sensivelmente seu crescimento, foram coletadas duas amostras de solo com raízes por parcela em duas camadas (0-0,10 m e 0,10-0,20 m), utilizando um cubo metálico de 0,10 $\mathrm{m} \times 0,10 \mathrm{~m} \times 0,10 \mathrm{~m}$, distanciado de $0,05 \mathrm{~m}$ das plantas e paralelamente à linha de semeadura. Em seguida, as raízes foram separadas do solo por lavagem em água corrente, utilizando-se de peneira de abertura de malha de 0,005 m. As raízes foram digitalizadas em "scanner" de leitura óptica, na resolução de 400 dpi, que forneceram o diâmetro médio $(\mathrm{mm})$ e o comprimento das raízes $(\mathrm{mm})$ pelo software "Delta-T Scan". Determinou-se o comprimento radicular $\left(\mathrm{cm} \mathrm{cm}^{-3}\right)$ por meio da divisão do comprimento radicular pelo volume de solo coletado. Na seqüência, as amostras foram secas em estufa a $65{ }^{\circ} \mathrm{C}$ até massa constante, para a determinação da massa seca das raízes por amostra (g), que foi dividida pelo volume de solo coletado obtendose a massa seca das raízes por volume de solo $\left(\mathrm{mg} \mathrm{cm}^{-3}\right)$.

Os dados coletados foram submetidos ao teste de normalidade e homocedasticidade, por meio do teste de Shapiro-Wilk. Os dados de comprimento radicular $\left(\mathrm{cm} \mathrm{cm}^{-3}\right)$, massa seca das raízes $\left(\mathrm{mg} \mathrm{cm}^{-3}\right)$ e superfície radicular $\left(\mathrm{cm}^{2} \mathrm{~cm}^{-3}\right)$ foram transformados em $1 / \sqrt{ } \mathrm{x}$.

Os resultados foram submetidos a análise de variância pelo teste $\mathrm{F}$ e, quando significativa, as médias dos tratamentos foram comparadas pelo teste de Tukey a $5 \%$ de probabilidade.

\section{RESULTADOS E DISCUSSÃO}


Houve interação significativa entre os sistemas de preparo do solo, níveis de palhada e camadas para todas características avaliadas (Tabela 1). Os resultados apresentados na Tabela 1 evidenciam que o PC promoveu aumento significativo $(p<0,001)$ na macroporosidade quando comparado ao PD e por sua vez o PD quando comparado ao PC e CM apresentou os maiores valores de densidade do solo $(p<0,005)$ e resistência mecânica do solo à penetração $(p<0,005)$, cujos resultados estão de acordo com STONE \& SILVEIRA (2001), onde o sistema com menor mobilização do solo, reduziu a macroporosidade e aumentou a densidade do solo e resistência mecânica do solo à penetração.

Tabela 1. Valores médios para macroporosidade, microporosidade, densidade do solo para os diferentes sistemas de preparo do solo (PS), níveis de palhada (P) e camadas (C) do Latossolo Vermelho.

\begin{tabular}{|c|c|c|c|c|}
\hline FV & $\begin{array}{l}\text { Macroporosidade } \\
\qquad\left(\mathrm{m}^{3} \mathrm{~m}^{-3}\right)\end{array}$ & $\begin{array}{l}\text { Microporosidade } \\
\qquad\left(\mathrm{m}^{3} \mathrm{~m}^{-3}\right)\end{array}$ & $\begin{array}{c}\text { Densidade } \\
\text { do solo } \\
\left(\mathrm{Mg} \mathrm{m}^{-3}\right)\end{array}$ & $\begin{array}{c}\mathrm{RP} \\
(\mathrm{MPa})\end{array}$ \\
\hline \multicolumn{5}{|c|}{ PREPARO DO SOLO } \\
\hline PC & $0,15 \mathrm{a}$ & $0,27 a b$ & $1,29 \mathrm{~b}$ & $1,17 \mathrm{~b}$ \\
\hline $\mathrm{CM}$ & $0,12 a b$ & $0,25 \mathrm{~b}$ & $1,30 \mathrm{~b}$ & $1,19 b$ \\
\hline PD & $0,09 \mathrm{~b}$ & $0,29 a$ & $1,39 a$ & $1,75 \mathrm{a}$ \\
\hline$C V(\%)$ & 41,89 & 14,17 & 6,25 & 5,13 \\
\hline \multicolumn{5}{|c|}{ PALHADA } \\
\hline SEM & $0,12 \mathrm{a}$ & $0,26 \mathrm{~b}$ & $1,33 \mathrm{a}$ & $1,39 \mathrm{a}$ \\
\hline COM & $0,12 a$ & $0,28 \mathrm{a}$ & $1,37 \mathrm{a}$ & $1,35 \mathrm{~b}$ \\
\hline$C V(\%)$ & 28,24 & 7,4 & 6,42 & 3,81 \\
\hline \multicolumn{5}{|c|}{ CAMADAS $(\mathrm{m})$} \\
\hline $0,03-0,06$ & $0,16 a$ & $0,26 \mathrm{~b}$ & $1,30 \mathrm{~b}$ & $1,16 \mathrm{~b}$ \\
\hline $0,13-0,16$ & $0,10 \mathrm{~b}$ & $0,27 \mathrm{a}$ & $1,37 \mathrm{a}$ & $1,48 \mathrm{a}$ \\
\hline $0,23-0,26$ & $0,09 \mathrm{~b}$ & $0,27 a b$ & $1,38 a$ & $1,48 a$ \\
\hline$C V(\%)$ & 27,76 & 6,76 & 4,37 & 3,19 \\
\hline \multicolumn{5}{|c|}{ TESTE F } \\
\hline PREPARO DO SOLO (PS) & $9,52^{* *}$ & 5,38 * & $8,73^{* *}$ & $402,05^{* *}$ \\
\hline PALHADA $(P)$ & 1,04 NS & $12,35^{* *}$ & 4,38 NS & 6,06 * \\
\hline CAMADAS $(C)$ & $53,57^{* *}$ & 3,31 * & $22,72^{* *}$ & $235,67^{* *}$ \\
\hline PS $\times P$ & 1,78 NS & $2,52^{\text {NS }}$ & 3,51 No & 3,65 Nড \\
\hline$P S \times C$ & 4,94 ** & $1,60^{\mathrm{NS}}$ & 9,08 ** & 328,82 ** \\
\hline$P \times C$ & 2,18 NS & $7,14^{* *}$ & 7,98 ** & 7,48 ** \\
\hline$P S \times P \times C$ & $2,21^{\mathrm{NS}}$ & 1,30 NS & $2,85^{\mathrm{NS}}$ & 2,94 NS \\
\hline
\end{tabular}

Fontes de variação (FV); Plantio Convencional (PC); Cultivo Mínimo (CM); Plantio Direto (PD); Médias seguidas pela mesma letra nas colunas não diferem entre si pelo teste de Tukey a $5 \%$ de probabilidade; * $\mathrm{e}^{* *}$ significativos respectivamente a $5 \%$ e a $1 \%$ de probabilidade e ${ }^{\text {NS }}$ não significativo.

Em relação a microporosidade (Tabela 1), o PD foi significativamente superior ao CM, não diferindo do PC. Esses resultados corroboram com PAULINO et al. (2004), que 
avaliaram a escarificação de um Latossolo Vermelho pós colheita da cana-de-açúcar e verificaram que a microporosidade aumentou de $0,29 \mathrm{~m}^{3} \mathrm{~m}^{-3}$ para $0,32 \mathrm{~m}^{3} \mathrm{~m}^{-3}$ onde não foi realizada a escarificação do solo ocasionada pela tríplice operação de cultivo da cana-de-açúcar.

Os resultados da avaliação da macroporosidade, microporosidade, densidade do solo e resistência mecânica do solo à penetração na camada de 0,03-0,06 m estão apresentados na Tabela 2. Os maiores valores de macroporosidade obtidos no PC $\left(0,19 \mathrm{~m}^{3} \mathrm{~m}^{-3}\right)$ e $\operatorname{CM}\left(0,18 \mathrm{~m}^{3} \mathrm{~m}^{-3}\right)$ comparado com o PD $\left(0,12 \mathrm{~m}^{3} \mathrm{~m}^{-3}\right)$ são devidos a excessiva mobilização do solo no PC ocasionado pela escarificação e gradagens e a ausência de revolvimento do solo associado ao tráfego excessivo de máquinas e implementos agrícolas no PD e acomodação natural das partículas, como atestam os resultados obtidos por SPERA et al. (2004) e COSTA et al. (2009).

Tabela 2. Valores médios para macroporosidade, densidade do solo e resistência à penetração para as diferentes camadas do Latossolo Vermelho.

\begin{tabular}{|c|c|c|c|}
\hline \multirow{2}{*}{ PREPARO DO SOLO } & \multicolumn{3}{|c|}{ CAMADAS (m) } \\
\hline & $0,03-0,06$ & $0,13-0,16$ & $0,23-0,26$ \\
\hline \multicolumn{4}{|c|}{ Macroporosidade $\left(\mathrm{m}^{3} \mathrm{~m}^{-3}\right)$} \\
\hline PC & 0,19 a $A$ & 0,14 a B & 0,10 a C \\
\hline $\mathrm{CM}$ & 0,18 a $A$ & 0,08 b B & 0,09 a B \\
\hline PD & $0,12 \mathrm{~b} \mathrm{~A}$ & $0,09 \mathrm{~b} \mathrm{AB}$ & 0,07 a $B$ \\
\hline \multicolumn{4}{|c|}{ Densidade do solo $\left(\mathrm{Mg} \mathrm{m}^{-3}\right)$} \\
\hline PC & $1,26 \mathrm{~b} \mathrm{~B}$ & 1,44 a $A$ & 1,39 a $A$ \\
\hline $\mathrm{CM}$ & $1,25 \mathrm{~b} \mathrm{~B}$ & $1,31 \mathrm{~b} A B$ & 1,36 a $A$ \\
\hline PD & 1,39 a $A$ & 1,38 a $A$ & 1,40 a A \\
\hline \multicolumn{4}{|c|}{ Resistência à Penetração (MPa) } \\
\hline PC & 0,50 c C & $1,56 \mathrm{~b} \mathrm{~A}$ & 1,46 b B \\
\hline $\mathrm{CM}$ & $1,09 \mathrm{~b} \mathrm{~B}$ & $1,16 \mathrm{c} \mathrm{B}$ & $1,34 \mathrm{cA}$ \\
\hline PD & 1,90 a $A$ & 1,72 a B & 1,64 a $C$ \\
\hline
\end{tabular}

Desdobramento das interações entre sistema de preparo do solo e camadas. Letras maiúsculas nas linhas comparam médias entre profundidades dentro de cada sistema e minúsculas nas colunas comparam médias entre os sistemas. Letras distintas indicam diferenças significativas a 5\% de probabilidade, pelo teste de Tukey.

Para a camada de 0,03-0,06 $\mathrm{m}$, a densidade do solo $\left(1,39 \mathrm{Mg} \mathrm{m}^{-3}\right)$ e resistência mecânica do solo à penetração $(1,90 \mathrm{MPa})$ mais elevadas no PD (Tabela 2) indicam a presença de compactação do solo, justificada pelo tráfego de veículos pesados na área por ocasião da colheita mecanizada da cana-de-açúcar durante cinco cortes consecutivos. Esses resultados estão de acordo com PAULINO et al. (2004) que 
afirmaram ser o intenso tráfego de maquinários um dos principais responsáveis pela compactação dos solos em áreas cultivadas com cana-de-açúcar. O PC e CM proporcionaram os menores valores de densidade $\left(1,26\right.$ e 1,25 $\left.\mathrm{Mg} \mathrm{m}^{-3}\right)$ e resistência mecânica do solo à penetração $(0,50 \mathrm{MPa}$ e $1,09 \mathrm{MPa})$, respectivamente, que podem ser atribuídos ao revolvimento do solo e a incorporação da palhada, corroborando com SOUZA et al. (2005). Além do excessivo revolvimento do solo causado pela gradagem, os maiores valores de macroporosidade, menores valores microporosidade, densidade do solo e resistência mecânica do solo à penetração, pode ser explicado pela incorporação das $15 \mathrm{t} \mathrm{ha}^{-1}$ de palhada nessa respectiva camada. ARAGON et al. (2000), trabalhando com amostras de solo com variações nos teores de matéria orgânica, verificaram um efeito de redução da densidade do solo e aumento na macroporosidade das amostras com os maiores teores de matéria orgânica e atribuíram esse efeito a redução da densidade do solo que é justificada pela matéria orgânica apresentar menor densidade específica que a fração mineral do solo.

Para a camada de 0,13-0,16 m (Tabela 2) o sistema PC proporcionou aumento da macroporosidade $\left(0,14 \mathrm{~m}^{3} \mathrm{~m}^{-3}\right)$ quando comparado ao $\mathrm{CM}\left(0,08 \mathrm{~m}^{3} \mathrm{~m}^{-3}\right)$ e $\operatorname{PD}(0,09$ $\mathrm{m}^{3} \mathrm{~m}^{-3}$ ) devido ao preparo do solo ocasionado pela gradagem mobilizar o solo até 0,15 m, concordando com os dados de COSTA et al. (2009). Nessa mesma camada, os resultados apresentados mostram que a densidade do solo de $1,44 \mathrm{Mg} \mathrm{m}^{-3}$ e resistência mecânica do solo à penetração de 1,56 MPa encontradas no PC e a densidade do solo de 1,38 $\mathrm{Mg} \mathrm{m}^{-3}$ e resistência mecânica do solo à penetração de 1,72 MPa encontradas no PD foram superiores a encontrada no $\mathrm{CM}$ de $1,31 \mathrm{Mg} \mathrm{m}^{-3}$ e $1,16 \mathrm{MPa}$, respectivamente.

$\mathrm{Na}$ Tabela 2 observa-se para o PC menores valores de macroporosidade, maiores valores de densidade do solo e resistência mecânica do solo à penetração nas camadas mais profundas quando comparada a camada mais superficial. A utilização de gradagens após a escarificação do solo nesse sistema levou a formação de uma camada mais compactada e de maior impedimento físico logo abaixo da camada de solo movimentada pelos implementos, fato este também observado por DE MARIA et al. (1999). STONE \& SILVEIRA (2001) verificaram aumento no valor da densidade do 
solo e resistência mecânica do solo à penetração após a camada de $0,1 \mathrm{~m}$, em solos preparados com grade.

Para as camadas mais profundas $(0,13-0,16$ e 0,23-0,26 m) no PD, houve redução da macroporosidade e resistência mecânica do solo à penetração e os resultados de densidade do solo permaneceram com o mesmo comportamento. HAKANSSON \& VOORHEES (1997b) verificaram que sistemas com pouco revolvimento do solo e tráfego de máquinas pesadas promovem aumento da densidade do solo até 0,40 m. Para SOUZA et al. (2005), o aumento da densidade do solo até 0,30 $\mathrm{m}$ nos sistemas de colheita de cana-de-açúcar deve-se ao tráfego de máquinas pesadas durante o plantio e colheita, corroborando os resultados de FLOWERS \& LAL (1998), que afirmaram que a principal causa da compactação em solos agrícolas é o tráfego de máquinas em operações de preparo do solo, semeadura, tratos culturais e colheita.

O nível de palhada interferiu na microporosidade $(p<0,001)$, aumentando a quantidade de microporos onde havia palha (Tabela 1). SOUZA et al. (2005), avaliando sistemas de colheita e manejo da palhada de cana-de-açúcar em um Latossolo Vermelho-Amarelo, também verificaram menores valores de microporos onde a canade-açúcar foi colhida com queima quando comparado com o tratamento onde a canade-açúcar foi colhida crua em todas camadas avaliadas.

Entre os níveis de palhada, o maior volume de microporos foi observado na camada de 0,03-0,06 $\mathrm{m}$ na presença de palhada (Tabela 3 ), sendo superior ao verificado nos tratamentos onde a palhada foi queimada.

A densidade do solo $\left(1,34 \mathrm{Mg} \mathrm{m}^{-3}\right)$ e a resistência mecânica do solo à penetração $(1,22 \mathrm{MPa})$ na camada de $0,03-0,06 \mathrm{~m}$ diferiu significativamente $(\mathrm{p}<0,001)$ para os tratamentos onde a palhada foi queimada, sendo observado menores valores de densidade do solo $\left(1,26 \mathrm{Mg} \mathrm{m}^{-3}\right)$ e resistência mecânica do solo à penetração $(1,10$ $\mathrm{MPa}$ ) nos tratamentos com palhada, independente do sistema de preparo do solo (Tabela 3). Esses resultados corroboram com os encontrados por SOUZA et al. (2005), que verificaram maior densidade do solo no sistema de colheita da cana-de-açúcar com queima e atribuíram isso, ao fato da superfície do solo no sistema de cana colhida com 
queima ficar mais exposta aos impactos das gotas de chuva no período com as maiores taxas de precipitação do ano.

Tabela 3. Valores médios para microporosidade, densidade do solo e resistência à penetração para os diferentes níveis de palhada.

\begin{tabular}{|c|c|c|c|}
\hline \multirow{2}{*}{ PALHADA } & \multicolumn{3}{|c|}{ CAMADAS $(m)$} \\
\hline & $0,03-0,06$ & $0,13-0,16$ & $0,23-0,26$ \\
\hline \multicolumn{4}{|c|}{ Microporosidade $\left(\mathrm{m}^{3} \mathrm{~m}^{-3}\right)$} \\
\hline SEM & $0,25 \mathrm{~b} \mathrm{~B}$ & 0,27 a $\mathrm{A}$ & 0,27 a $A$ \\
\hline COM & 0,28 a $A$ & 0,28 a A & 0,27 a A \\
\hline \multicolumn{4}{|c|}{ Densidade do solo $\left(\mathrm{Mg} \mathrm{m}^{-3}\right)$} \\
\hline SEM & 1,34 a B & 1,35 a $\mathrm{A}$ & $1.40 \mathrm{a} A$ \\
\hline COM & 1,26 b B & 1,40 a A & 1,37 a $A B$ \\
\hline \multicolumn{4}{|c|}{ Resistência à Penetração (MPa) } \\
\hline SEM & $1,22 \mathrm{a} B$ & 1,49 a $\mathrm{A}$ & 1,48 a $A$ \\
\hline COM & $1,10 \mathrm{~b} \mathrm{~B}$ & 1,47 a $A$ & 1,48 a $A$ \\
\hline
\end{tabular}

Desdobramento das interações entre níveis de palhada e camadas. Letras maiúsculas nas linhas comparam médias entre profundidades dentro de cada nível de palhada e minúsculas nas colunas comparam médias entre os níveis de palhada. Letras distintas indicam diferenças significativas a $5 \%$ de probabilidade, pelo teste de Tukey.

Houve interação significativa entre os sistemas de preparo do solo e os parâmetros de crescimento do sistema radicular do amendoim (Tabela 4). Os diferentes sistemas de preparo do solo proporcionaram diferenças significativas no diâmetro das raízes ( $p<0,001)$, comprimento radicular $(p<0,001)$, massa seca das raízes $(p<0,005)$ e superfície radicular $(p<0,001)$.

$\mathrm{Na}$ Tabela 4, verifica-se que o diâmetro das raízes no PD de 0,46 mm, onde a densidade do solo se encontra em $1,39 \mathrm{Mg} \mathrm{m}^{-3}$ e a resistência mecânica do solo à penetração de $1,75 \mathrm{MPa}$ (Tabela 1), foi superior ao diâmetro das raízes no PC e CM com $0,41 \mathrm{~mm}$ e $0,39 \mathrm{~mm}$ de diâmetro, respectivamente, onde se encontram a densidade de $1,29 \mathrm{Mg} \mathrm{m}^{-3}$ e resistência mecânica do solo à penetração de 1,17 MPa para o $\mathrm{PC}$ e densidade de $1,30 \mathrm{Mg} \mathrm{m}^{-3}$ e resistência mecânica do solo à penetração de 1,19 MPa para o CM. MELLO IVO \& MIELNICZUK (1999), avaliando a distribuição das raízes de milho sob três manejos de preparo do solo, também verificaram maior diâmetro das raízes no sistema de plantio direto em relação ao convencional, uma vez que os maiores valores de resistência mecânica do solo à penetração e densidade do solo no sistema de plantio direto levaram as raízes a apresentarem deformações morfológicas pelo aumento do diâmetro, o qual, segundo BENGOUGH \& MULLINS 
(1990), resulta principalmente em aumento da espessura do córtex, sendo isso conseqüência do aumento do número de células por unidade de comprimento de raiz. GUIMARÃES et al. (2002) em feijoeiro, BEUTLER \& CENTURION (2004) em soja e LEONEL et al. (2007b) em amendoim, também verificaram que o diâmetro médio das raízes dessas culturas em Latossolo Vermelho aumentou na camada com maior valor de densidade do solo e resistência mecânica do solo à penetração.

Independentemente do sistema de preparo do solo e da presença da palhada as raízes coletadas na camada de 0-0,10 m apresentaram diferenças significativas $(p<0,001)$, indicando menor diâmetro quando comparada com as raízes coletadas na camada de 0,10-0,20 m (Tabela 4). Possivelmente, o maior diâmetro das raízes encontrado na camada mais profunda se deve ao fato de que a maior compactação ocorreu respectivamente nessa camada para o PC, levando a formação de uma camada de maior impedimento físico logo abaixo da camada de solo movimentada pelas sucessivas gradagens. Dessa forma, o impedimento mecânico do solo na camada abaixo de 0,13 m diminuiu a taxa de elongação radicular devido à redução da divisão celular meristemática e do crescimento radicular, tornando as raízes menos pontiagudas e, conseqüentemente, provocando maior engrossamento das raízes nessa camada, conforme constatado por TORRES \& SARAIVA (1999). 
Tabela 4. Valores médios para diâmetro radicular, comprimento radicular, massa das raízes, superfície radicular para os diferentes sistemas de preparo do solo (PS), níveis de palhada $(\mathrm{P})$ e camadas $(\mathrm{C})$ do Latossolo Vermelho.

\begin{tabular}{|c|c|c|c|c|}
\hline FV & $\begin{array}{l}\text { Diâmetro } \\
(\mathrm{mm})\end{array}$ & $\begin{array}{l}\text { Comprimento } \\
\text { radicular } \\
\left(\mathrm{cm} \mathrm{cm}^{-3}\right)\end{array}$ & $\begin{array}{c}\text { Massa seca } \\
\text { das raízes } \\
\left(\mathrm{mg} \mathrm{cm}^{-3}\right)\end{array}$ & $\begin{array}{l}\text { Superfície radicular } \\
\qquad\left(\mathrm{cm}^{2} \mathrm{~cm}^{-3}\right)\end{array}$ \\
\hline \multicolumn{5}{|c|}{ PREPARO DO SOLO } \\
\hline PC & $0,41 \mathrm{~b}$ & $4,07 \mathrm{a}$ & $6,76 \mathrm{a}$ & $3,39 \mathrm{a}$ \\
\hline $\mathrm{CM}$ & $0,39 \mathrm{~b}$ & $2,92 \mathrm{~b}$ & $5,74 a b$ & $2,74 \mathrm{~b}$ \\
\hline PD & $0,46 \mathrm{a}$ & $2,98 \mathrm{~b}$ & $5,13 b$ & $2,62 b$ \\
\hline$C V(\%)$ & 14,09 & 27,26 & 32,06 & 25,29 \\
\hline \multicolumn{5}{|c|}{ PALHADA } \\
\hline SEM & $0,41 \mathrm{a}$ & $3,39 a$ & $6,08 \mathrm{a}$ & $3,00 \mathrm{a}$ \\
\hline COM & $0,41 \mathrm{a}$ & $3,25 \mathrm{a}$ & $5,68 \mathrm{a}$ & $2,84 \mathrm{a}$ \\
\hline$C V(\%)$ & 15,50 & 27,95 & 29,87 & 28,61 \\
\hline \multicolumn{5}{|c|}{ CAMADAS (m) } \\
\hline $0-0,1$ & $0,38 \mathrm{~b}$ & $3,52 \mathrm{a}$ & $6,69 \mathrm{a}$ & $3,18 \mathrm{a}$ \\
\hline $0,1-0,2$ & $0,43 a$ & $3,12 \mathrm{~b}$ & $5,07 \mathrm{~b}$ & $2,66 \mathrm{~b}$ \\
\hline$C V(\%)$ & 8,65 & 17,83 & 23,51 & 19,81 \\
\hline \multicolumn{5}{|c|}{ TESTE F } \\
\hline PREPARO DO SOLO (PS) & $18,47^{\star *}$ & $12,21^{\star *}$ & 4,56 * & $7,54^{* *}$ \\
\hline PALHADA $(\mathrm{P})$ & $0,02^{\mathrm{NS}}$ & 0,40 NS & $0,96^{\mathrm{NS}}$ & $0,63^{\mathrm{NS}}$ \\
\hline CAMADAS (C) & 32,46 ** & 8,02 ** & 24,57 ** & 14,52 ** \\
\hline$P S \times P$ & $1,90^{\text {NS }}$ & $0,18^{\text {NS }}$ & 2,01 NS & $0,84^{\text {NS }}$ \\
\hline$P S \times C$ & $0,13^{\mathrm{NS}}$ & 15,20 ** & 10,23 ** & 12,84 ** \\
\hline $\mathrm{P} \times \mathrm{C}$ & $1,63^{\text {NS }}$ & $2,15^{\text {NS }}$ & 3,00 NS & $2,32^{\text {NS }}$ \\
\hline$P S \times P \times C$ & 1,54 NS & 2,60 NS & 2,03 NS & 2,84 NS \\
\hline
\end{tabular}

Fontes de variação (FV); Plantio Convencional (PC); Cultivo Mínimo (CM); Plantio Direto (PD); Médias seguidas pela mesma letra nas colunas não diferem entre si pelo teste de Tukey a $5 \%$ de probabilidade; * $e^{* *}$ significativos respectivamente a $5 \%$ e a $1 \%$ de probabilidade e ${ }^{N S}$ não significativo. Dados originais de comprimento radicular, massa seca de raízes e superfície radicular foram transformados em $1 / \sqrt{ } \mathrm{x}$.

Para a camada de $0-0,10 \mathrm{~m}$, os menores valores de densidade do solo $(1,29 \mathrm{Mg}$ $\left.\mathrm{m}^{-3}\right)$, resistência mecânica do solo à penetração $(1,17 \mathrm{MPa})$ e maior valor macroporosidade $\left(0,15 \mathrm{~m}^{3} \mathrm{~m}^{-3}\right)$ encontrados no PC (Tabela 1) influenciaram positivamente o crescimento radicular, massa seca das raízes e superfície radicular (Tabela 5) quando comparado com o PD, que por sua vez apresentaram os maiores valores de densidade do solo, resistência mecânica do solo à penetração e menor valor de macroporosidade (Tabela 1). Os valores de macroporosidade $\left(0,09 \mathrm{~m}^{3} \mathrm{~m}^{-3}\right)$ encontrados no $P D$ atingiram valores inferiores a $0,10 \mathrm{~m}^{3} \mathrm{~m}^{-3}$, quando a resistência mecânica do solo à penetração foi igual a $1,75 \mathrm{MPa}$, indicando maior risco de limitação ao crescimento radicular. LEONEL et al. (2007b) avaliando a influência da compactação do solo no crescimento radicular em um Latossolo Vermelho, verificaram que o 
aumento da resistência mecânica do solo à penetração partir de 1,16 MPa causou redução linear em todos os parâmetros do crescimento do sistema radicular do amendoim. Para CAMARGO \& ALLEONI (1997), os macroporos constituem a principal rota de crescimento das raízes e, desta forma, os solos compactados prejudicam o crescimento radicular. Segundo THOMASSON (1978) e SECCO et al. (2004), os solos devem possuir uma macroporosidade mínima de $0,10 \mathrm{~m}^{3} \mathrm{~m}^{-3}$ para o crescimento e desenvolvimento satisfatório das plantas. Dessa forma, no PC as raízes ficaram mais concentradas na camada de 0-0,10 m, onde o solo está com menor valor de densidade e resistência mecânica do solo à penetração e maior valor de macroporosidade em decorrência do revolvimento ocasionado pelo escarificador e gragadens.

Tabela 5. Valores médios para comprimento radicular, massa das raízes e superfície radicular para os diferentes sistemas de preparo do solo.

\begin{tabular}{|c|c|c|}
\hline \multirow{2}{*}{ PREPARO DO SOLO } & \multicolumn{2}{|c|}{ CAMADAS (m) } \\
\hline & $0-0,10$ & $0,10-0,20$ \\
\hline \multicolumn{3}{|c|}{ Comprimento radicular $\left(\mathrm{cm} \mathrm{cm}^{-3}\right)$} \\
\hline PC & 4,80 a $A$ & 3,34 a B \\
\hline $\mathrm{CM}$ & $2,95 \mathrm{~b} \mathrm{~A}$ & 2,89 a $A$ \\
\hline PD & 2,81 b A & 3,15 a $A$ \\
\hline \multicolumn{3}{|c|}{ Massa seca das raízes $\left(\mathrm{mg} \mathrm{cm}^{-3}\right)$} \\
\hline PC & 8,56 a $A$ & 4,97 a B \\
\hline $\mathrm{CM}$ & $6,35 \mathrm{~b} \mathrm{~A}$ & 5,13 a $B$ \\
\hline PD & $5,15 \mathrm{~b} \mathrm{~A}$ & 5,11 a B \\
\hline \multicolumn{3}{|c|}{ Superfície radicular $\left(\mathrm{cm}^{2} \mathrm{~cm}^{-3}\right)$} \\
\hline PC & 4,13 a $A$ & 2,66 a B \\
\hline $\mathrm{CM}$ & $2,88 \mathrm{~b} \mathrm{~A}$ & 2,62 a $A$ \\
\hline PD & $2,54 \mathrm{~b} \mathrm{~A}$ & 2,70 a $A$ \\
\hline
\end{tabular}

Desdobramento das interações entre sistema de preparo do solo e camadas. Letras maiúsculas nas linhas comparam médias entre profundidades dentro de cada sistema e minúsculas nas colunas comparam médias entre os sistemas. Letras distintas indicam diferenças significativas a $5 \%$ de probabilidade, pelo teste de Tukey. Dados originais de comprimento radicular, massa seca de raízes e superfície radicular foram transformados em $1 / \sqrt{ }$.

O aumento da densidade do solo e resistência mecânica do solo à penetração encontrados no PC a partir da camada de 0,13 m levou a redução significativa do comprimento radicular, massa seca das raízes e superfície radicular nessa camada. As raízes ultrapassaram a camada de $0,13 \mathrm{~m}$ em menor quantidade devido ao maior impedimento físico do solo existente abaixo da camada movimentada pelas sucessivas gradagens (Tabela 5). Segundo CAMARGO \& ALLEONI (1997), a compactação do solo reduz o tamanho dos poros a ponto de impedir a passagem da raiz principal, 
intensificando a ocorrência de formação de raízes laterais com diâmetros menores, resultando em formação de sistema radicular denso e raso, que no campo dificilmente sobrevive a condições de seca.

Para o CM e PD não houve diferenças para o comprimento radicular, massa seca das raízes e superfície radicular (Tabela 5) nas diferentes camadas avaliadas. Segundo NOGUEIRA \& MANFREDINI (1983), em condições de campo a camada compactada não se apresenta de forma continua de densidade do solo constante, ao longo de grandes extensões de área. Esses mesmos autores verificaram que a densidade do solo na camada compactada, situada a $0,20 \mathrm{~m}$ de profundidade no solo, variou de $1,25 \mathrm{Mg} \mathrm{m}^{-3}$ a 1,45 $\mathrm{Mg} \mathrm{m}^{-3}$, em apenas $0,50 \mathrm{~m}$ de distância horizontal, significando que, em condições de campo, as raízes penetram nos pontos de menor resistência. Dessa forma, as diferentes operações de preparo do solo alteraram as propriedades físicas do solo, tais como a densidade do solo, a porosidade e a resistência do solo à penetração das raízes. Estas alterações podem afetar a distribuição, a quantidade e a morfologia das raízes com reflexos no crescimento da parte aérea das plantas (KLEPKER \& ANGHINONI, 1995). 


\section{CONCLUSÕES}

A maior mobilização do solo ocasionado pela escarificação e gradagens, com ou sem incorporação da palhada, reduziu a compactação na camada mais superficial em comparação aos demais sistemas de preparo, proporcionando menores valores de densidade do solo, resistência mecânica do solo à penetração e, maiores valores de macroporosidade.

Os maiores valores de densidade do solo, resistência mecânica do solo à penetração e menor valor de macroporosidade encontrados no PD na camada mais superficial, influenciaram negativamente o comprimento radicular, a massa seca das raízes, superfície radicular e aumentou o diâmetro radicular.

A densidade de $1,44 \mathrm{Mg} \mathrm{m}^{-3}$ e resistência mecânica do solo à penetração de 1,56 MPa encontradas no PC na camada de 0,13-0,16 m reduziu o crescimento das raízes abaixo dessa camada. 


\section{CAPÍTULO 4 - INFLUÊNCIA DO SISTEMA DE PREPARO DO SOLO EM ÁREA DE REFORMA DE CANAVIAL NOS COMPONENTES DE PRODUTIVIDADE DO AMENDOIM}

RESUMO: O amendoim é cultivado principalmente em sucessão a cana-de-açúcar nas áreas de reforma de canavial. Devido ao aumento das áreas de colheita mecanizada sem queima da cana no estado de São Paulo, os restos culturais permanecem sobre a superfície do solo. Assim, o objetivo deste trabalho foi avaliar diferentes sistemas de preparo do solo: Plantio Convencional (PC), Cultivo Mínimo (CM) e Plantio Direto (PD), com dois níveis de palhada remanescente da cana-de-açúcar colhida mecanicamente, nos componentes de produtividade das cultivares de amendoim (IAC Tatu ST e Runner IAC 886). No dia 23 de novembro de 2007 foi semeado o amendoim em um Latossolo Vermelho distrófico no município de Guariba (SP). O delineamento experimental utilizado foi em blocos casualizados, com parcelas subdivididas e seis repetições. Os tratamentos constituíram de três diferentes sistemas de preparo do solo e dois níveis de palhada (sem e com). Os componentes de produtividade da planta foram avaliados por meio da altura das plantas, número de ramos por planta, massa seca da parte aérea, massa das vagens por planta, produtividade em casca e o rendimento de grãos do amendoim. Nos sistemas com permanência da palhada, independente da incorporação, houve incrementos na altura de plantas, aumento na massa seca da parte aérea e redução no peso das vagens por planta para o cultivar Runner IAC 886. Os sistemas de preparo onde as $15 \mathrm{tha}^{-1}$ de palhada remanescentes da cana-de-açúcar permaneceram sobre a superfície do solo sem incorporação, influenciou negativamente a produtividade e rendimento dos grãos do amendoim para os dois cultivares.

Palavras Chave: Plantio direto, cultivo mínimo, desenvolvimento da planta, palhada de cana-de-açúcar, produtividade, Arachis hypogaea L. 


\section{INTRODUÇÃO}

Nos últimos anos as áreas cultivadas com cana-de-açúcar têm se expandido consideravelmente, sendo o Brasil o maior produtor mundial desta cultura. Por sua vez, o cultivo do amendoim no País ocupa aproximadamente 115 mil ha e cerca de 77\% da produção nacional se concentra no estado de São Paulo (AGRIANUAL, 2009). Essa produção advém principalmente das áreas de reforma de canaviais, nas quais o amendoim é uma alternativa viável a ser utilizada na sucessão com a cana-de-açúcar (BOLONHEZl et al., 2005). Dentre os benefícios do uso do amendoim nas áreas de reforma de canavial, destaca-se a redução do custo de implantação do canavial (ORTOLAN, 1979), aumento da produtividade de colmos (ALEONI \& BEAUCLAIR, 1995), boa fixação biológica de nitrogênio (BORGES et al. 2007), diminuição na população de nematóides que ocorrem na cana-de-açúcar (MOURA et al., 1997), conservação do solo devido à cobertura do solo numa época de alta precipitação pluvial (VOLK et al., 2004), ciclagem de nutrientes (FEITOSA et al., 1993) e redução da incidência de plantas daninhas durante o ciclo da cana-de-açúcar (LORENZI, 1983).

Preparo do solo é o conjunto de operações realizadas antes da semeadura, para revolver o solo, expondo-o ao ar, ao sol e à ação das máquinas, além de incorporar restos de culturas, fertilizantes ou corretivos, e enterrar a cobertura vegetal como forma de eliminar plantas daninhas (FOLLE \& SEIXAS, 1986). Além disso, historicamente, é considerada uma prática cultural essencial, devido a peculiaridade morfofisiológica da planta de amendoim, que desenvolve suas vagens no solo necessitando, de um solo friável, plano e livre de resíduos na superfície da cultura anterior (BOLONHEZI et al. 2005).

Recentemente, em razão da legislação, foram determinados prazos para a eliminação gradativa do emprego das queimadas para despalha da cana-de-açúcar nos canaviais paulistas, ocorrendo, conseqüentemente, um aumento do uso de máquinas colhedoras de cana crua, que deixam sobre a superfície do solo, após a colheita, aproximadamente $15 \mathrm{t} \mathrm{ha}^{-1}$ de matéria seca, podendo formar uma camada de palha de 0,08 a $0,10 \mathrm{~m}$ de espessura (BOLONHEZI et al. 2005). Segundo BORKERT et al. 
(2003), a decomposição da palhada de gramíneas é excelente fornecedora de nutrientes às culturas sucessoras. BRAZ et al. (2004) verificaram que o milheto, a braquiária e o panicum têm capacidade de acumular grande quantidade de nutrientes. Contudo, são relativamente recentes os estudos sobre a influência dos resíduos culturais deixados na superfície do solo sobre a produtividade de culturas cultivadas em sucessão.

No Brasil, trabalhos que avaliam a implantação da cultura do amendoim, em sistema plantio direto ou em preparos reduzidos, são quase inexistentes. Além disso, os poucos resultados de pesquisa para cultura do amendoim são inconsistentes. COLVIN et al., (1988) verificaram que para altas produtividades é necessária alguma movimentação na superfície do solo. Entretanto, BOLONHEZl et al. (2007) não observaram diferenças para produtividade e número de estruturas reprodutivas do amendoim entre o sistema convencional de preparo do solo e os sistemas conservacionistas sem a utilização de grade e arado em áreas de renovação de canavial.

O tipo de preparo do solo pode influenciar a incorporação e a decomposição da palhada e, conseqüentemente, a liberação de nutrientes para a cultura em sucessão (ARGENTA et al., 2001). Contudo, pouco se sabe sobre o efeito do tipo de manejo da palhada sobre o desempenho da cultura do amendoim, em sucessão a cana-de-açúcar.

Assim, o presente trabalho teve como objetivo avaliar, em condições de campo, os componentes de produtividade de dois cultivares de amendoim cultivado em um Latossolo Vermelho submetido a diferentes sistemas de preparo do solo e dois níveis de palhada remanescente da cana-de-açúcar colhida mecanicamente.

\section{MATERIAL E MÉTODOS}

O experimento foi realizado em Guariba (SP), nas coordenadas geográficas $21^{\circ}$ 22 ' 46 " de latitude sul e 48 $15^{\prime}$ '02" de longitude oeste e altitude média de $618 \mathrm{~m}$. O clima é do tipo Cwa, segundo o sistema de classificação de Köppen, com verão quente e inverno seco, precipitação média anual de $1.388 \mathrm{~mm}$ e temperatura média de $21^{\circ} \mathrm{C}$. 
As precipitações pluviais durante o ciclo da cultura estão apresentadas na Figura 1. O solo da área experimental é um Latossolo Vermelho distrófico, típico, textura argilosa, A moderado, caulinítico, hipoférrico (LVd), segundo o Sistema Brasileiro de Classificação de Solos (EMBRAPA, 2006). O solo apresentou $377 \mathrm{~g} \mathrm{~kg}^{-1}$ de argila, $38 \mathrm{~g} \mathrm{~kg}^{-1}$ de silte e $585 \mathrm{~g} \mathrm{~kg}^{-1}$ de areia na camada de 0-0,2 m e $377,5 \mathrm{~g} \mathrm{~kg}^{-1}$ de argila, $38,5 \mathrm{~g} \mathrm{~kg}^{-1}$ de silte e $585 \mathrm{~g} \mathrm{~kg}^{-1}$ de areia na camada de 0,2-1,0 m de profundidade.

Os tratamentos foram realizados em área submetida à colheita de cana-deaçúcar, durante cinco cortes consecutivos, sendo apenas o primeiro corte realizado com a queima prévia da palhada, sendo os demais com colheita mecanizada. A dessecação da área submetida aos tratamentos foi realizada em 10 de novembro de 2007, utilizando-se $2.400 \mathrm{~g}$ de i.a. por ha-1 de glyphosate, quando a cana-de-açúcar variedade RB 867515 estava com 0,7 m de altura. No dia 21 de novembro de 2007, foi realizada a queima da palhada remanescente nos tratamentos com essa característica e aplicado os diferentes sistemas de preparo do solo.

Os tratamentos utilizados constituíram-se de três sistemas de preparo do solo: Plantio Direto - PD (o solo foi revolvido apenas ao longo das linhas, por ocasião da semeadura, após a erradicação química da soqueira); Cultivo Mínimo - CM (foi utilizado nesse sistema, um escarificador de hastes rígidas, marca Baldan, modelo ASDADR $05 \mathrm{H}$, de arrasto, com discos de corte de palhada, cinco hastes e rolo destorroador, a uma profundidade de $0,20 \mathrm{~m}$, após a erradicação química da soqueira); Plantio Convencional - PC (foi utilizado nesse sistema uma grade intermediária, marca Marchesan Tatu, modelo GAICR (24 discos), de arrasto, a uma profundidade de 0,15 m, por duas vezes consecutivas, uma passada do escarificador e uma passada de grade niveladora, marca Super Tatu, modelo GNF (44 discos), de arrasto, na profundidade de $0,10 \mathrm{~m}$, após a erradicação química da soqueira. Para quantificação da palhada foi utilizado um quadro metálico de $0,25 \mathrm{~m}^{2}$ arremessado aleatoriamente em 20 pontos do experimento, determinada a média das quantidades de palha e extrapolada para 1,0 ha, totalizando $15 \mathrm{t} \mathrm{ha}^{-1}$ de palha remanescente.

O delineamento experimental utilizado foi em blocos casualizados, com parcelas subdivididas, seis repetições, sendo que os tratamentos principais se constituíram de 
diferentes sistemas de preparo do solo e os secundários de dois níveis de palhada, totalizando 36 unidades experimentais de 7,0 $\mathrm{m} \times$ 3,6 m.

O solo foi analisado quimicamente antes da instalação do experimento, segundo metodologia citada por RAIJ et al. (1987), na camada de 0-0,2 m, que revelou os seguintes resultados: $21 \mathrm{~g} \mathrm{dm}^{-3}$ de matéria orgânica; 5,2 de $\mathrm{pH}\left(\mathrm{CaCl}_{2}\right) ; 17 \mathrm{mg} \mathrm{dm}^{-3} \mathrm{de}$ $\mathrm{P}$ (resina); 1,8 $\mathrm{mmol}_{\mathrm{c}} \mathrm{dm}^{-3}$ de K $\mathrm{K}^{+} ; 24 \mathrm{mmol}_{\mathrm{c}} \mathrm{dm}^{-3}$ de $\mathrm{Ca}^{2+} ; 14 \mathrm{mmol}_{\mathrm{c}} \mathrm{dm}^{-3} \mathrm{de} \mathrm{Mg}^{2+} ; 25$ $\mathrm{mmol}_{\mathrm{c}} \mathrm{dm}^{-3}$ de $\mathrm{H}+\mathrm{Al}$; SB de $39,8 \mathrm{mmol}_{\mathrm{c}} \mathrm{dm}^{-3}$; CTC de $64,8 \mathrm{mmol}_{\mathrm{c}} \mathrm{dm}^{-3}$ e saturação por bases de $61 \%$. O solo foi adubado com $0,3 \mathrm{t} \mathrm{ha}^{-1}$ do adubo formulado 02-20-20, para a obtenção da produtividade esperada de amendoim de $3 \mathrm{t} \mathrm{ha}^{-1}$, segundo RAIJ et al. (1997).

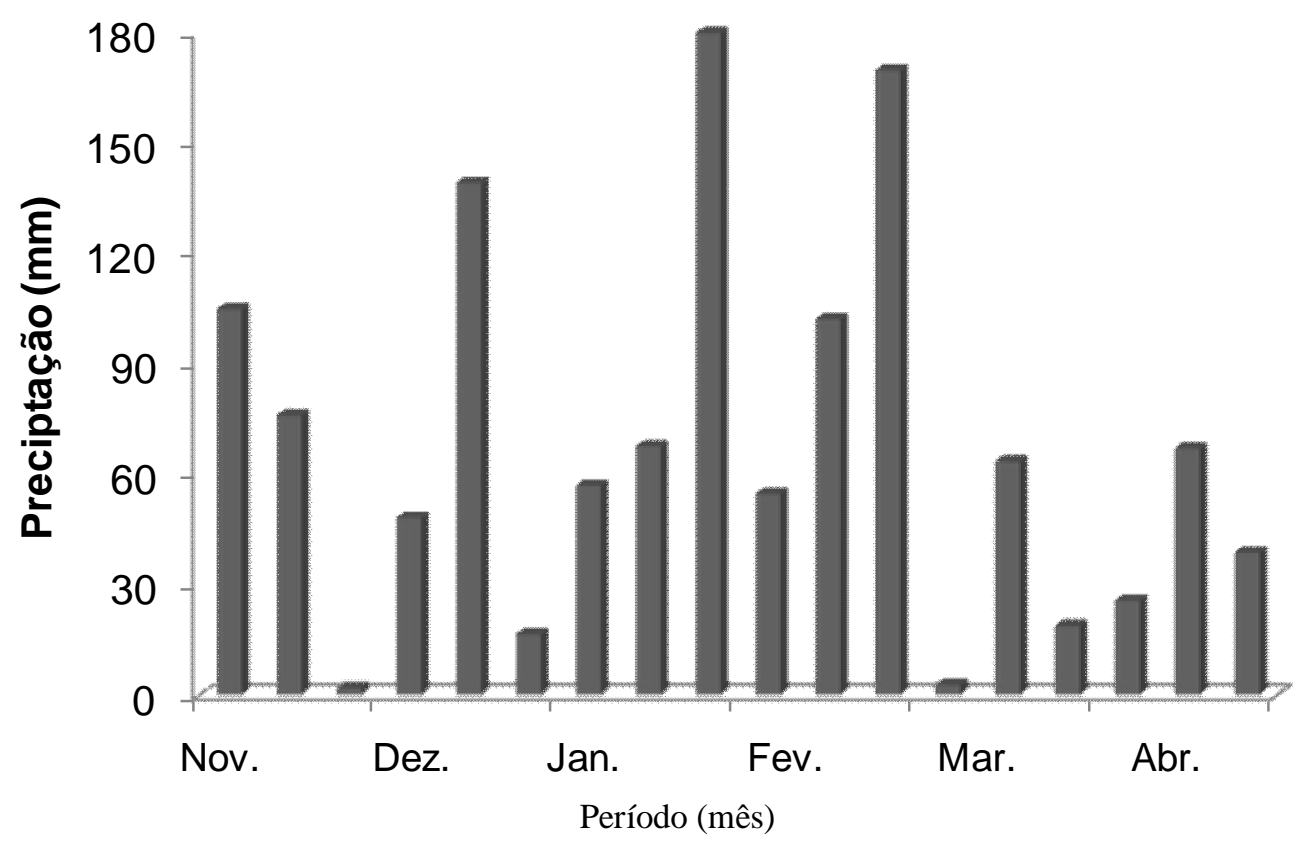

Figura 1. Precipitação pluvial a cada dez dias no período de 01 de novembro de 2007 a 30 de abril de 2008.

No dia 23 de novembro de 2007 foram semeadas as cultivares de amendoim IAC Tatu ST de porte ereto e ciclo precoce e a cultivar Runner IAC 886 de porte rasteiro e ciclo tardio, ambas utilizando o espaçamento de $0,9 \mathrm{~m}$ entrelinhas com distribuição de 30 sementes por metro. Após 15 dias, a partir da emergência, foi feito o desbaste 
ajustando-se a densidade para 20 e 15 plantas por metro para as cultivares IAC Tatu ST e Runner IAC 886, respectivamente (BOLONHEZI et al., 2005). A parcela experimental foi constituída por quatro linhas de 7,0 m de comprimento, considerandose como parcela útil as duas linhas centrais e descontando 1,0 m em cada extremidade das linhas, totalizando uma parcela útil de $9,0 \mathrm{~m}^{2}$.

O controle das plantas daninhas foi realizado mediante a uma aplicação do herbicida imazapic (150 $\mathrm{g} \mathrm{ha}^{-1}$ do i.a.), no dia 13/12/2007. Para o controle de pragas, principalmente trips (Enneothrips flavens e Caliothrips brasiliensis) e lagarta do pescoço vermelho (Stegasta bosquela), foram realizadas as pulverizações com os inseticidas metamidofós e deltametrina ( $600 \mathrm{~g} \mathrm{ha}^{-1}$ do i.a. e $5 \mathrm{~g} \mathrm{ha}^{-1}$ do i.a., respectivamente) nos dias 21/12/2007, 25/01/2008 e 26/02/2008, alternado com tiametoxan + lambdacialotrina (34,9 $\mathrm{g} \mathrm{ha}^{-1}$ do i.a. $+26,3 \mathrm{~g} \mathrm{ha}^{-1}$ do i.a.) nos dias 08/01/2008, 08/02/2008 e 05/03/2008. Para controle de doenças, principalmente cercosporioses (Cercosporidium personatum e Cercospora arachidicola) e verrugose (Sphaceloma arachidis), foram realizadas pulverizações com os fungicidas clorotalonil e tiofanato metílico (1.000 $\mathrm{g} \mathrm{ha}^{-1}$ do i.a. e $250 \mathrm{~g} \mathrm{ha}^{-1}$ do i.a., respectivamente) nos dias 21/12/2007, 25/01/2008 e 26/02/2008, alternado com epoxiconazole + piraclostrobina (30 $\mathrm{g} \mathrm{ha}^{-1}$ do i.a. $+79,8 \mathrm{~g}$ ha $^{-1}$ do i.a.) nos dias 08/01/2008, 08/02/2008 e 05/03/2008.

Os componentes de produtividade da planta avaliados foram: altura das plantas (cm), número de ramos secundários por planta, massa seca da parte aérea $\left(\mathrm{kg} \mathrm{ha}^{-1}\right)$, massa das vagens por planta $(\mathrm{g})$ obtida após a colheita em dez plantas coletadas aleatoriamente por repetição. A produtividade em casca e o rendimento de grãos do amendoim foram obtidos extrapolando-se a produção de vagens da área útil da parcela para um hectare e ajustada a umidade padrão de armazenamento de $8 \%$.

Os dados coletados foram submetidos ao teste de normalidade e homocedasticidade, por meio do teste de Shapiro-Wilk. Os resultados foram submetidos a análise de variância pelo teste $\mathrm{F}$ e, quando significativa, as médias dos tratamentos foram comparadas pelo teste de Tukey a $5 \%$ de probabilidade. 


\section{RESULTADOS E DISCUSSÃO}

Houve interação significativa entre os sistemas de preparo do solo e níveis de palhada para produtividade e rendimento para ambas cultivares. Para o cultivar Runner IAC 886, os resultados apresentados na Tabela 1, evidenciam que os tratamentos com palhada promoveram aumento significativo $(p<0,001)$ na altura das plantas e massa seca da parte aérea, além de não promover diferenças significativas $(p \geq 0,005)$ para o número de ramos por planta quando comparado com os tratamentos onde a palhada foi queimada. Para o cultivar IAC Tatu ST os diferentes sistemas de preparo do solo e níveis de palhada não influenciaram o número de ramos por planta e a massa seca da parte aérea (Tabela 2), havendo superioridade na altura de plantas quando a palhada foi mantida no sistema. Para BALBINO et al. (1996), os sistemas agrícolas com cobertura do solo pelos restos culturais reduzem as perdas de água por evaporação na superfície do solo. Provavelmente, a menor disponibilidade de água ocorrida durante o desenvolvimento da planta nos tratamentos onde a palhada foi queimada, levou à menor produção de massa seca da parte aérea e menor altura das plantas para a cultivar Runner IAC 886. Além disso, a menor disponibilidade hídrica pode ter afetado a absorção de nutrientes, reduzindo-a, o que explica também, a menor produção de massa seca da parte aérea e menor altura das plantas nos cultivos onde a palhada foi queimada. Redução na absorção de nutrientes provocada pela deficiência hídrica com reflexo na altura das plantas e menor massa seca da parte aérea também foi constatada por CRUSCIOL et al. (2003).

A produção de vagens por planta ( planta $^{-1}$ ) aumentou de forma significativa em resposta à queima da palhada para o cutivar Runner IAC 886 (Tabela 1), comportamento que se deve, provavelmente, a maior formação de vagens desse cultivar ser realizado pelas ramificações nas entrelinhas da cultura, onde predominava a maior quantidade de palhada e devido a esse cultivar possuir porte prostrado e os primeiros nós da base dos ramos laterais serem sempre vegetativos, formando poucas vagens logo abaixo da planta. Para o cultivar IAC Tatu ST (Tabela 2), não houve redução significativa desse componente de produtividade, pois as vagens foram 
formadas logo abaixo da planta devido ao seu porte ereto e os primeiros nós da base das ramificações terem caráter reprodutivo e onde o solo é minimamente revolvido pelos discos de corte da palhada e de deposição das sementes no solo, o que favorece o contato das vagens formadas com o solo.

Para a produtividade $\left(\mathrm{kg} \mathrm{ha}^{-1}\right)$ e rendimento de grãos $\left(\mathrm{kg} \mathrm{ha}^{-1}\right)$, constatou-se interação significativa entre os efeitos dos fatores estudados com diferenças entre os níveis de palhada, exercendo maior influência para essas características avaliadas quando foi realizado o PD para ambas cultivares (Tabela 3 e 4). Para o cultivar Runner IAC 886, independente do sistema de preparo do solo e onde a palhada foi queimada 0 $\mathrm{PC}$ e o PD foram superiores ao $\mathrm{CM}$, indicando a viabilidade do $\mathrm{PD}$ sem resíduos vegetais para a cultura do amendoim (Tabela 3). Entretanto, na presença da palhada, para esse mesmo cultivar, houve diferença significativa, sendo a produtividade de $3.075,7 \mathrm{~kg} \mathrm{ha}^{-1}$ observada no PC, enquanto que a menor produtividade $2.528,5 \mathrm{~kg} \mathrm{ha}^{-1}$ foi observada no PD, representando uma redução de 17,8\% na produtividade e, para o cultivar IAC Tatu ST o PD reduziu em 18,2\% quando comparado ao PC (Tabela 4). Para o PC as sucessivas gradagens picaram e incorporaram as $15 \mathrm{t} \mathrm{ha}^{-1}$ de palhada 0 que contribuiu para a formação das vagens no solo. Entretanto, o CM e PD com palhada reduziram a produtividade do amendoim, pois nesses tratamentos a palhada não foi picada e incorporada ao solo. Para COLVIN et al. (1988) e WRIGHT (1991) altas quantidades de resíduos vegetais no solo podem funcionar como um fator de impedimento físico a penetração do ginóforo do amendoim no solo e com isso prejudicar a formação das vagens. O ginóforo é uma estrutura alongada que se forma após o florescimento, também denominada "esporão". Este cresce em direção ao solo por possuir geotropismo positivo, sendo que o fruto só se forma sob a superfície. $\mathrm{Na}$ extremidade do ginóforo estão localizados os tecidos que darão origem à vagem contendo as sementes. O ginóforo penetra no solo, pois necessita de ausência de luz e de absorção de nutrientes para a formação do fruto (MELOUK \& SHOKES, 1995). Dessa forma, parte das vagens, por receberem o estimulo de ausência de luz entre a camada de 8 a $10 \mathrm{~cm}$ de espessura de palhada, desenvolve suas vagens entre essa camada e não no solo, o que pode contribuir com a menor produtividade nos 
tratamentos onde a palhada não foi incorporada. Todavia, CRUSCIOL \& SORATO (2007) destacam a possibilidade de se semear o amendoim em sistema plantio direto, em sucessão às culturas do milheto, braquiária ou panicum, mesmo com grande quantidade de palha na superfície $\left(8,9 \mathrm{t} \mathrm{ha}^{-1}\right)$, sem que haja prejuízo no estabelecimento e produtividade da cultura. 
ถก

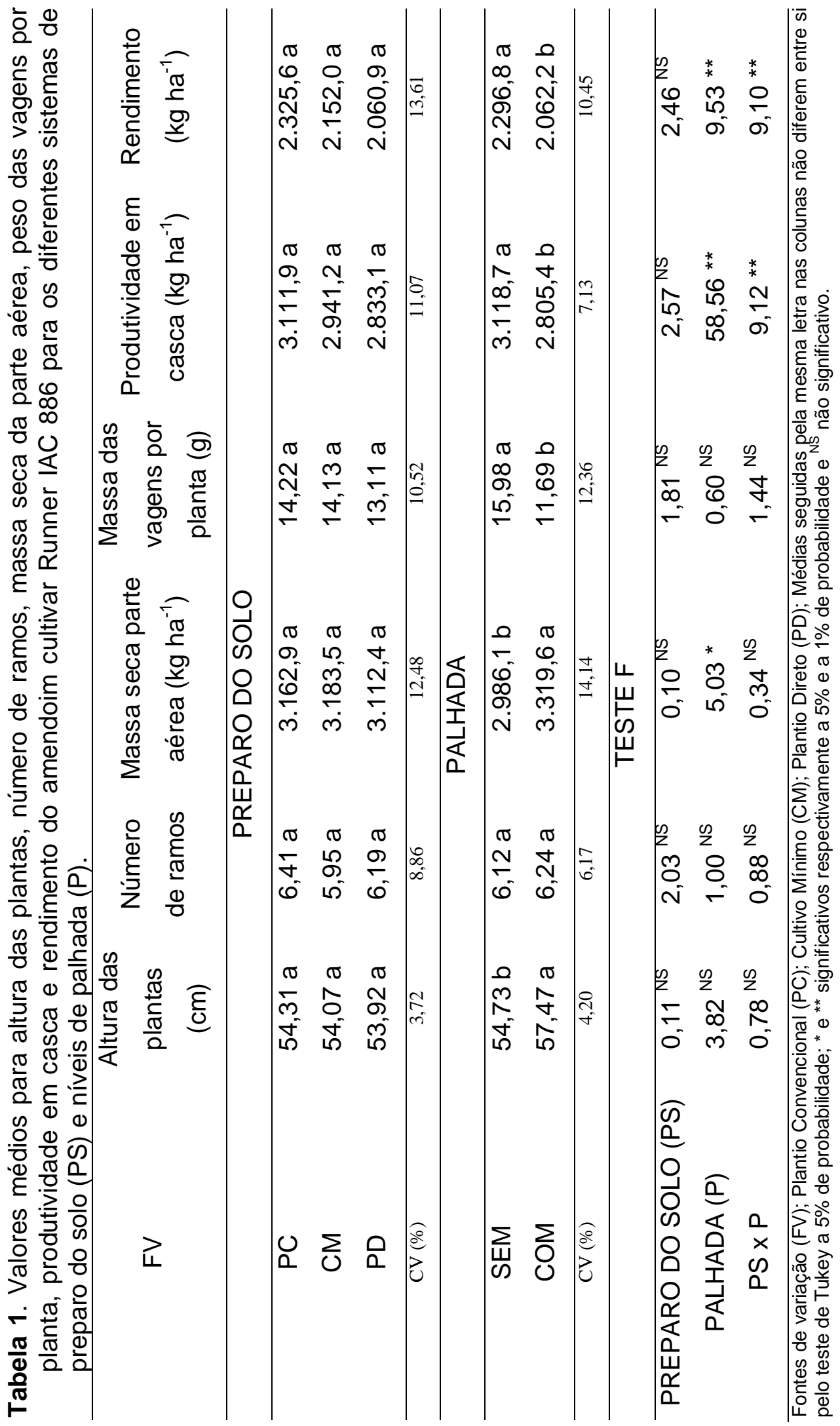


๓

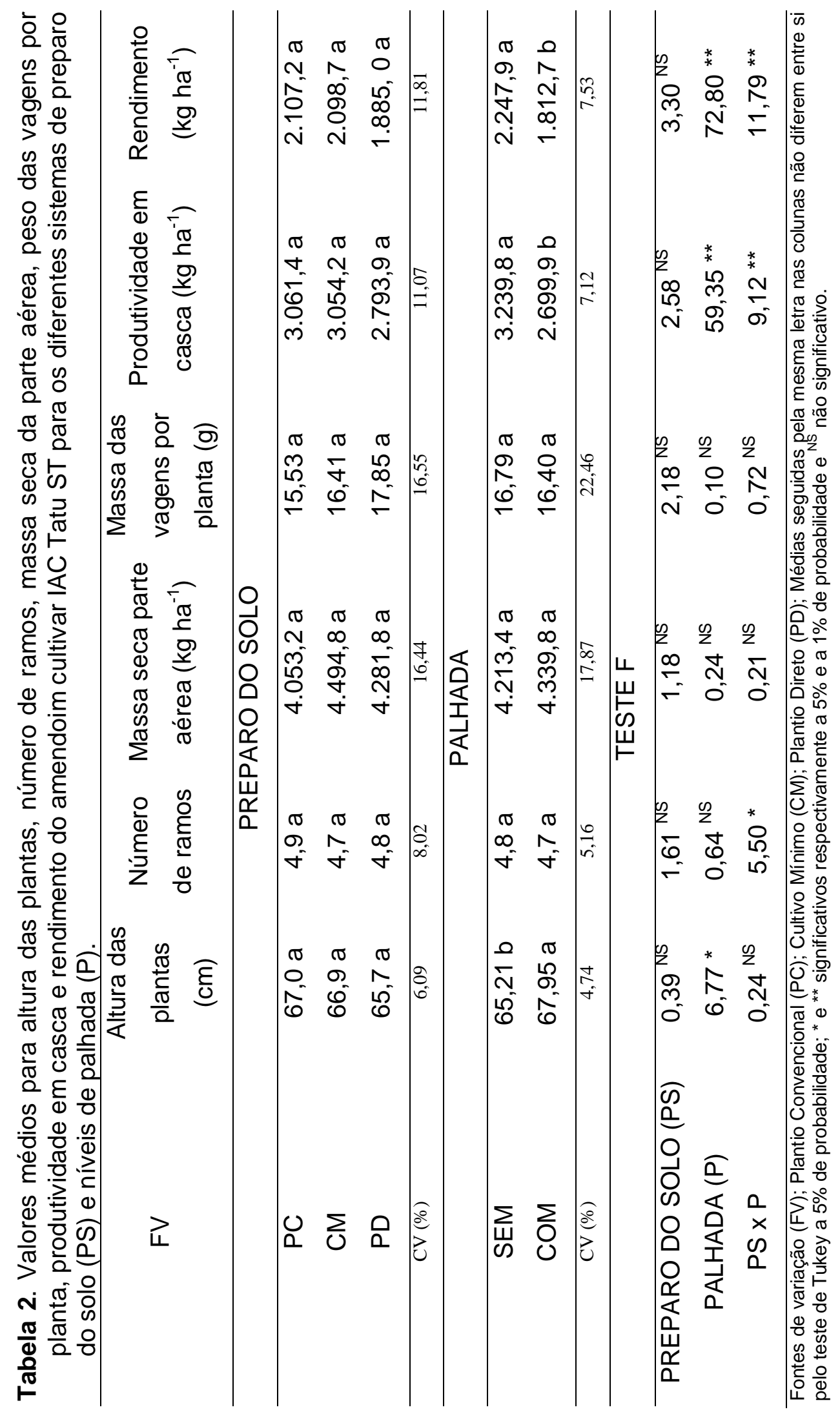


A inferioridade de produtividade nos tratamentos onde a palhada permaneceu no sistema, está também associada a maior altura das plantas o que pode ter levado ao menor número de vagens por planta, indicando que uma quantidade menor de ginóforos tenha penetrado no solo, promovendo menor quantidade de frutos desenvolvidos. A planta de amendoim produz grande quantidade de ginóforos, contudo, a eficiência efetiva dessa estrutura formar um fruto viável é baixa, devido a uma serie de fatores fisiológicos e morfológicos relacionados a planta. De acordo com HARTZOOK \& GOLDIM (1967), o amendoim não aproveita todas suas flores e, sim, apenas as que se localizam até $15 \mathrm{~cm}$ acima do solo vão dar origem a vagens maduras e desenvolvidas. Dessa forma, como na presença da palhada houve um maior crescimento das plantas (Tabela 1 e 2) e conseqüente aumento no comprimento dos entrenós, a formação dos ginóforos ocorreram em uma distância maior em relação ao solo, prejudicando a formação das vagens.

Tabela 3. Valores médios para produtividade e rendimento de grãos do amendoim cultivar Runner IAC 886 para os diferentes sistemas de preparo do solo e níveis de palhada.

\begin{tabular}{ccc}
\hline \multirow{2}{*}{ Preparo do solo } & \multicolumn{2}{c}{ Níveis de palhada } \\
\cline { 2 - 3 } & \multicolumn{1}{c}{ SEM } \\
\hline Produtividade em casca $\left(\mathrm{kg} \mathrm{ha}^{-1}\right)$ \\
\hline PC & $3.412,2 \mathrm{a} \mathrm{A}$ \\
CM & $2.806,5 \mathrm{~b} \mathrm{~A}$ & $3.075,7 \mathrm{a} \mathrm{A}$ \\
PD & $3.137,6 \mathrm{a} \mathrm{A}$ & $2.811,7 \mathrm{ab} \mathrm{A}$ \\
& Rendimento de grãos $\left(\mathrm{kg} \mathrm{ha}^{-1}\right)$ \\
PC & $2.558,6$ a A & $2.528,5 \mathrm{~b} \mathrm{~B}$ \\
CM & $2.040,1 \mathrm{~b} \mathrm{~A}$ & $2.092,6 \mathrm{a} \mathrm{A}, 9$ a A \\
PD & $2.291,6$ ab A & $1.830,2 \mathrm{~b} \mathrm{~B}$
\end{tabular}

Desdobramento das interações entre sistema de preparo do solo e níveis de palhada. Letras maiúsculas nas linhas comparam médias entre os níveis de palhada dentro de cada sistema e minúsculas nas colunas comparam médias entre os sistemas. Letras distintas indicam diferenças significativas a $5 \%$ de probabilidade, pelo teste de Tukey.

O rendimento de grãos foi maior no sistema onde a palhada foi queimada, em relação aos tratamentos onde a palhada permaneceu no sistema para ambas cultivares (Tabela 1 e 2). Estes resultados concordam com a maioria das pesquisas publicadas (GRICHAR \& SMITH, 1991; WRIGHT \& 
PORTER, 1991; GRICHAR, 1998; JORDAN et al., 2001), as quais relatam ganhos de pelo menos 3\% no rendimento de grãos nos sistemas onde o preparo do solo é realizado com grade e arado quando comparado com os preparos conservacionistas como o PD e CM. Para os tratamentos onde a palhada foi queimada, os diferentes sistemas de preparo do solo não influenciaram o rendimento dos grãos de amendoim (Tabelas 3 e 4).

Tabela 4. Valores médios para produtividade e rendimento de grãos do amendoim cultivar IAC Tatu ST para os diferentes sistemas de preparo do solo e níveis de palhada.

\begin{tabular}{|c|c|c|}
\hline \multirow{2}{*}{ Preparo do solo } & \multicolumn{2}{|c|}{ Níveis de palhada } \\
\hline & SEM & COM \\
\hline \multicolumn{3}{|c|}{ Produtividade em casca $\left(\mathrm{kg} \mathrm{ha}^{-1}\right)$} \\
\hline PC & $3.122,1$ a $A$ & $3.000,7$ a $\mathrm{A}$ \\
\hline $\mathrm{CM}$ & $3.463,4$ a A & $2.645,1 \mathrm{ab} \mathrm{B}$ \\
\hline PD & $3.134,1$ a $A$ & $2.453,8$ b B \\
\hline \multicolumn{3}{|c|}{ Rendimento de grãos $\left(\mathrm{kg} \mathrm{ha}^{-1}\right)$} \\
\hline PC & $2.151,2$ a A & $2.063,3$ a $A$ \\
\hline $\mathrm{CM}$ & $2.422,8$ a A & $1.774,7 \mathrm{ab} \mathrm{B}$ \\
\hline PD & $2.169,7$ a A & $1.600,3$ b B \\
\hline
\end{tabular}

Desdobramento das interações entre sistema de preparo do solo e níveis de palhada. Letras maiúsculas nas linhas comparam médias entre os níveis de palhada dentro de cada sistema e minúsculas nas colunas comparam médias entre os sistemas. Letras distintas indicam diferenças significativas a $5 \%$ de probabilidade, pelo teste de Tukey.

Quando houve a permanência da palhada no sistema, o maior rendimento de grãos foi observado no PC quando comparado ao PD. Provavelmente devido a incorporação dos resíduos vegetais proporcionados pelas sucessivas gradagens, o que favorece a penetração dos ginóforos e o desenvolvimento das vagens no solo. Para o CM e PD onde a palhada foi queimada, observou-se maior rendimento de grãos quando comparado com os tratamentos onde a palhada permanece sobre a superfície do solo (Tabela 3 e 4). $O$ amendoim absorve nutrientes do solo também pelos ginóforos e vagens em desenvolvimento (BOLHUIS \& STUBBS, 1955). Considerando o aspecto qualitativo o cálcio é um dos nutrientes mais importantes para cultura do amendoim (SKELTON \& SHEAR, 1971). O cálcio é um nutriente importante 
para a divisão celular e sua deficiência resulta em grãos mal granados e redução no tamanho das vagens (MALAVOLTA, 2006). Boa parte do cálcio absorvido pelos ginóforos e vagens em desenvolvimento permanece nessas respectivas estruturas, contribuindo para o melhor desenvolvimento dos frutos, dessa forma, a presença do cálcio na região do solo onde as vagens se desenvolvem é fundamental (SKELTON \& SHEAR, 1971). Possivelmente, nas condições de excessiva quantidade de resíduos vegetais sobre a superfície do solo, as vagens foram formadas no meio da palhada, tendo menor superfície de contato com o solo, o que desfavorece a absorção de cálcio e os demais nutrientes, favorecendo o menor crescimento e desenvolvimento das vagens e menor rendimento de grãos. 


\section{CONCLUSÕES}

Nos sistemas com permanência da palhada, independente da incorporação, houve incremento na altura de plantas para ambas cultivares, aumento na massa seca da parte aérea e redução na massa seca das vagens por planta apenas para o cultivar Runner IAC 886.

Os sistemas de preparo onde as $15 \mathrm{t} \mathrm{ha}^{-1}$ de palhada remanescentes da cana-de-açúcar permaneceram sobre a superfície do solo sem incorporação, influenciou negativamente a produtividade e rendimento dos grãos do amendoim para os dois cultivares. 


\section{REFERÊNCIAS BIBLIOGRÁFICAS}

AGRIANUAL 2009: Anuário da agricultura brasileira. São Paulo: FNP Consultoria e Comércio, 2008. p. 455-490.

ALBUQUERQUE, J. A.; REINERT, D. J. Densidade radicular do milho considerando os atributos de um solo com horizonte B textural. Revista Brasileira de Ciência do solo, Viçosa, v.25, p.539-549, 2001.

ALLEONI L.R.F.; BEAUCLAIR, E.G.F. Cana-de-açúcar cultivada após milho e amendoim, com diferentes concentrações de adubo. Scientia Agrícola, Piracicaba, v.53, n.3, p.409-415, 1995.

ANDRADE, C. E. ; SANTOS, M. F. P. Manejo do solo visando maior disponibilidade de água para a cultura do café. In: ZAMBOLIN, L. (Ed.). Efeitos da irrigação sobre a qualidade e produtividade do café. Viçosa: UFV, 2004. p. 385-416.

ANDRADE, C.L.T.; COELHO, E.F.; COURO, L.; SILVA, E.L. Parâmetros de solo-água para a engenharia de irrigação e ambiental. In: CONGRESSO BRASILEIRO DE ENGENHARIA AGRÍCOLA, 27, 1998, Poços de Calda-MG, . Anais...: UFLA/SBEA, 1998. p.1-132.

ANGULO, R.J.; ROLOFF, G.; SOUZA, M.L.P. Correlação entre diferentes formas de determinação e representação da estabilidade e resistência dos agregados do solo. Revista Brasileira de Ciência do Solo, Campinas, v.8, n.1, p.7-12, 1984.

ARAGON, A.; GARCIA, M.G.; FILGUEIRA, R.R.; PACHEPSKY, Y. Maximum compactibility of Argentine soils from the Proctor test; the relationship with organic carbon and water content. Soil \& Tillage Research, Amsterdam, v.56, p. 197-204, 2000. 
ARGENTA, G.; SILVA, P.R.F. da; FLECK, N.G.; BORTOLINI, C.G.; NEVES, R.; AGOSTINETTO, D. Efeitos do manejo mecânico e químico da aveia-preta no milho em sucessão e no controle do capim-papuã. Pesquisa Agropecuária Brasileira, Brasília, v.36, p.851-860, 2001.

ARSHAD, M. A.; LOWERY, B.; GROSSMAN, B. Physical tests for monitoring soil quality. In: DORAN, J. W.; JONES, A. J. Methods for assessing soil quality. Madison: Soil Science Society of America, Madson, p.123-141, 1996 (Special Publication, 49).

BALBINO, L.C.; MOREIRA, J.A.A.; SILVA, J.G. da; OLIVEIRA, E.F.; OLIVEIRA, I.P. Plantio direto. In: ARAÚJO, R.S.; RAVA, C.A.; STONE, L.F.; ZIMMERMANN, M.J. de O. (Coord.). Cultura do feijoeiro comum no Brasil. Piracicaba: Potafos, 1996. p.301-352.

BARBER, R.G. Persistence of loosened horizons and soybean yield increases in Bolivia. Soil Science Society of America Journal, Oxford, v.58, p.943-950, 1994.

BENGHOUGH, A.G.; MULLINS,C.E. Mechanical impedance to root growth: a review of experimental techniques and root growth responses. Journal of Soil Science, London, v.41, p. 341-341, 1990.

BERTOL, I., SCHICK, J., MASSARIOL, J.M. Propriedades físicas de um Cambissolo Húmico álico afetadas pelo manejo do solo após cinco cultivos. Ciência Rural, Santa Maria, v.30, p. 91-95, 2000.

BEUTLER, A. N.; CENTURION, J. F. Compactação do solo no desenvolvimento radicular e na produtividade da soja. Pesquisa Agropecuária Brasileira, Brasília, v.39, p. 581-588, 2004.

BEUTLER, A.N.; CENTURION, J.F.; da SILVA, A.P. Soil resistance to penetration and least limiting water range for soybean yield in a haplustox from Brazil. Brazilian Archives of Biology and Technology, Curitiba, v.48, p. 863-871, 2005. 
BLAIR, N.; FAULKNER, R.D.; TILL, A.R.; SANCHES, P. Decomposition of ${ }^{13} \mathrm{C}$ and ${ }^{15} \mathrm{~N}$ labeled plant residue materials in two different soil types and its impact on soil carbon, nitrogen, aggregate stability, and aggregate formation, Australian Journal of Soil Research, Melbourne, v.43, p.873-886, 2005.

BLAKE, G. R.; HARTGE, K. H. Bulk density. In: KLUTE, A. Methods of soil analysis. Madison: American Society of Agronomy, v.1, p. 377-382, 1986.

BOLHUIS, G.C.; STUBBS, R.W. The influence of calcium and other elements on the frutification on the peanut, in connection with absorption capacity of its gynophores. Journal of Agricultural Science, Oxford, v.3, p.220-237, 1955.

BOLONHEZI, D.; MUTTON, M.A.; MARTINS, A.L.M. Sistemas conservacionistas de manejo do solo para amendoim cultivado em sucessão à cana crua. Pesquisa Agropecuária Brasileira, Brasília, v.42, p. 939-947, 2007.

BOLONHEZI, D.; SANTOS, R. C. dos; GODOY, I.J. de. Manejo cultural do amendoim. In: SANTOS, R.C. dos. (Ed.). O agronegócio do amendoim no Brasil. Campina Grande: Embrapa Algodão, 2005. p.193-244.

BORGES, W.L.; SILVA, C.E.R.; XAVIER, G.R.; RUMJANEK, N.G. Nodulação e fixação biológica de nitrogênio de assessos de amendoim com estirpes nativas de rizóbios. Revista Brasileira de Ciências Agrárias, Recife, v.2, p.32-37, 2007.

BORKERT, C.M.; GAUDÊNCIO, C. de A.; PEREIRA, J.E.; PEREIRA, L.R.; OLIVEIRA JÚNIOR, A. de. Nutrientes minerais na biomassa da parte aérea em culturas de cobertura de solo. Pesquisa Agropecuária Brasileira, Brasília, v.38, p.143-153, 2003.

BRADFORD, J. M. The penetration resistance in a soil with well-defined structural units. Soil Science Society American Journal, Madson, v. 44, p. 601-606, 1980. 
BRAZ, A.J.B.P.; SILVEIRA, P.M. da; KLIEMANN, H.J.; ZIMMERMANN, F.J.P. Acumulação de nutrientes em folhas de milheto e dos capins braquiária e mombaça. Pesquisa Agropecuária Tropical, Goiânia, v.34, p.83-87, 2004.

BRONICK, C.J.; LAL, R. Soil structure and management: a review. Geoderma, Amsterdam, v.124, p.3-22, 2005.

CALEGARI, A.; CASTRO FILHO, C.; TAVARES FILHO, J.; RALISCH, R.; GUIMARÃES, M.F. Melhoria da agregação do solo através do sistema plantio direto. Semina: Ciências Agrárias, Londrina, v.27, p.147-158, 2006.

CAMARGO, O.A.; ALLEONI, L.R.F. Compactação do solo e o desenvolvimento das plantas. Piracicaba: USP, 1997. 132p.

CAMPOS, B.C.; REINERT, D.J.; NICOLODI, R.; CASSOL, L.C. Dinâmica da agregação induzida pelo uso de plantas de inverno para cobertura do solo. Revista Brasileira de Ciência do Solo, Viçosa, v.23, p.383-391, 1999.

CAMPOS, B.C.; REINERT, D.J.; NICOLODI, R.; RUEDELL, J. \& PETRERE, C. Estabilidade estrutural de um Latossolo Vermelho-Escuro distrófico após sete anos de rotação de culturas e sistemas de manejo de solo. Revista Brasileira de Ciência do Solo, Campinas, v.19, p.121-126, 1995.

CARPENEDO, V.; MIELNICZUK, J. Estado de agregação e qualidade dos agregados de latossolos roxos, submetidos a diferentes sistemas de manejo. Revista Brasileira de Ciência do Solo, Campinas, v.14, p.99-105, 1990.

CARVALHO FILHO, A.; SILVA, R.P.; FERNANDES, A.L.T. Compactação do solo em cafeicultura irrigada. Uberaba: Universidade de Uberaba, 2004. 44 p. (UNIUBE - Boletim Técnico, n. 3).

CASTRO FILHO, C.; MUZILLI, O.; PODANOSCHI, A.L. Estabilidade de agregados e sua relação com o teor de carbono orgânico num Latossolo Roxo 
distrófico, em função de sistemas de plantio, rotações de culturas e métodos de preparo das amostras. Revista Brasileira de Ciência do Solo, Viçosa, v.22, p.527-538, 1998.

CINTRA, F. L. D.; MIELNICZUK, J. Potencial de algumas espécies vegetais para recuperação de solos com propriedades físicas degradadas. Revista Brasileira de Ciência do Solo, Campinas, v.7, p.323-327, 1983.

COLVIN, D.L.; BRECKE, B.J.; WHITTY, E.B. Tillage variable for peanut production. Peanut Science, Dawson, v.15, p.94-97, 1988.

COSTA, A.; AlBUQUERQUE, J.A.; MAFRA, A.L.; SILVA, F.R. Propriedades físicas do solo em sistemas de manejo na integração agricultura-pecuária. Revista Brasileira de Ciência do Solo, Viçosa, v.33, p. 235-244, 2009.

CRUSCIOL, C.A.C.; LAZARINI, E.; SORATTO, R.P. Efeito da aplicação de calcário no sulco de semeadura sobre a nutrição e produtividade de amendoim semeado em diferentes épocas no cultivo da seca. Científica, Jaboticabal, v.31, p.201-209, 2003.

CRUSCIOL, C.A.C.; SORATO, R.P. Nutrição e produtividade do amendoim em sucessão ao cultivo de plantas de cobertura no sistema plantio direto. Pesquisa Agropecuária Brasileira, Brasília, v.42, p.1553-1560, 2007.

DA ROS, C.O.; SECCO, D.; FIORIN, J.E.; PETRERE, C.; CADORE, M.A.; PASA, L. Manejo do solo a partir de campo nativo: efeito sobre a forma e estabilidade da estrutura ao final de cinco anos. Revista Brasileira de Ciência do Solo, Viçosa, v.21, p.241-247, 1997.

DALLA ROSA, A. Práticas mecânicas e culturais na recuperação de características físicas de solos degradados pelo cultivo, Solo Santo Ângelo (Latossolo Roxo distrófico). Porto Alegre, Universidade Federal do Rio Grande do Sul, 1981. 138p. (Dissertação de Mestrado). 
DANIELSON, R. E.; SUTHERLAND, P. L. Porosity. In: KLUTE, A. Methods of soil analysis. 2. ed. Madison: American Society of Agronomy, part.1, p. 443-461, 1986.

DE MARIA, I. C.; CASTRO, O. M.; SOUZA DIAS, H. Atributos físicos do solo e crescimento radicular de soja em Latossolo Roxo sob diferentes métodos de preparo do solo. Revista Brasileira de Ciência do Solo, Viçosa, v.23, p. 703-709, 1999.

DEXTER, A.R. Advances in characterization of soil strucuture. Soils \& Tillage Research, Amsterdam, v.11, n.1, p.199-238, 1988.

EDWARDS, A. P.; BREMNER, J. M. Dispersion of soil particles by sonic vibration. Journal of Soil Science, Oxford, v.18, p.47-63, 1967.

EMPRESA BRASILEIRA DE PESQUISA AGROPECUÁRIA. Centro Nacional e Pesquisa em Solos. Sistema Brasileiro de Classificação de Solos. Rio de Janeiro: Embrapa-Solos, 2006. 306 p.

EPSTEN, E. Nutrição mineral das plantas: princípios e perspectivas. São Paulo: EDUSP, 1975. 344 p.

FEITOSA, C.T.; NOGUEIRA, S.S.S.; GERIN, M.A.N.; RODRIGUES FILHO, F.S.O. Avaliação do crescimento e da utilização de nutrientes pelo amendoim. Scientia Agrícola, Piracicaba, v.50, p. 427-437, 1993.

FLOWERS, M. D.; LAL, R. Axle load and tillage effects on soil physical properties and soybean grain yield on a molic ochraqualf in nothwest Ohio. Soil \& Tillage Research, Amsterdam, v.48, p. 21-35, 1998.

FOLLE, S.M.; SEIXAS, J.M. Mecanização agrícola. In: GOEDERT, W.J. (Ed.). Solos dos cerrados: tecnologia e estratégias de manejo. São Paulo : NOBEL/Embrapa-CPAC, 1986. p.385-408.

FONTENELE, W.; SALVIANO, A.A.C.; MOUSINHO, F.E.P. Atributos físicos de um Latossolo Amarelo sob sistemas de manejo no cerrado piauiense. Revista Ciência Agronômica, Fortaleza, v. 40, p. 194-202, 2009. 
GERARD, C. J.; MEHTH, H. C.; HINOJOSA, F. Root growth in a clay soil. Soil Science, Baltimore, v. 114, p. 37-49, 1972.

GREGORY, W.C.; REDDY, M.S. Root growth in na pearl millet/groundnut. Field Crops Reserch, New Delhi, v.5, p. 241-252, 1982.

GRICHAR, W.J. Long term effects of three tillage systems on peanut grade, yield, and stem rot development. Peanut Science, Dawson, v.25, p.59-62, 1998.

GRICHAR, W.J.; SMITH, O.D. Effects of tillage systems on Southern blight and pod yield of five runner peanut genotypes. Peanut Science, Dawson, v.18, p.144-147, 1991.

GUIMARÃES, C. M.; STONE, L. F.; MOREIRA, J. A. A. Compactação do solo na cultura do feijoeiro. II: efeito sobre o desenvolvimento radicular e da parte aérea. Revista Brasileira de Engenharia Agrícola e Ambiental, Campina Grande, v.6, p.213-218, 2002.

HAKANSSON, I.; VOORHEES, W. B. Chapter on soil compaction. In: LAL, R.; BLUM, W. H.; VALENTIN, C.; STEWART, B. A., eds. Methods for assessment of soil degration. Boca raton: Lewis Publishers, 576p. 1997a.

HAKANSSON, I.; VOORHEES, W.B. Soil compaction. In: LAL, R.; BLUM, W.H.; VALENTIN, C. (Ed.). Methods for assessment of soil degradation. Boca Raton: Lewis, p. 167-179, 1997b.

HAKANSSON, I.; VOORHEES, W.B.; RILEY, H. Vehicle and wheel factors influencing soil compaction and crop response in different traffic regimes. Soil \& Tillage Research, Amsterdam, v.11, p.239-282, 1988.

HARTZOOK, A.; GOLDIM, E. On the problem of produtivy in groundnuts (Arachis hypogaea L.). Oleagineaux, Paris, v.22, p.677-678, 1967. 
HAYNES, R.J.; BEARE, M.H. Influence of six crop species on aggregate stability and some labile organic matter fractions. Soil Biology and Biochemistry, Oxford, v.29, p.1647-1653, 1997.

HERNANI, L.C.; SALTON, J.C.; FABRÍCIO, A.C.; DEDECEK, R.; ALVES JÚNIOR, M. Perdas por erosão e rendimentos de soja e de trigo em diferentes sistemas de preparo de um Latossolo Roxo de Dourados (MS). Revista Brasileira de Ciência do Solo, Viçosa, v.21, p.667-676, 1997.

JORDAN, D.L.; BARNES, J.S.; BOGLE, C.R.; NADERMAN, G.C.; ROBERSON, G.T.; JOHNSON, P.D. Peanut response to tillage and fertilization. Agronomy Journal, Madison, v.93, p.1125-1130, 2001.

KEMPER, W. D.; CHEPIL, W.S. Size distribution of aggregates. In: BLACK, C.A.; EVANS, D.D.; WHITE, J.L.; ENSMINGER, L.E.; CLARK, F.E., eds Methods of soil analysis : physical and mineralogical propeties, including statistcs of measurement and sampling. Part 1. Madison, American Society of Agronomy, 1965. p.499-510.

KEMPER, W.D.; ROSENAU, R.C. Aggregate stability and size distribution. In: KLUTE, A. (Ed.). Methods of soil analysis. Madison : American Society of Agronomy, 1986. part 1, p.425-442. (ASA Agronomy, 9).

KIEHL, E. J. Manual de Edafologia. São Paulo: Ceres, 1979. 262 p.

KLADIVKO, E.J. Residue effect on soil physical properties. In: Managing agricultural residues. Florida: Lewis Publisher, 1994. p.121-141.

KLEPKER, D.; ANGHINONI, I.; Caracteristicas físicas e químicas do solo afetados por métodos de preparo e métodos de adubação. Revista Brasileira de Ciência do Solo, Viçosa, v.19, p. 395-401, 1995. 
KLUTE, A. Water retention: laboratory methods. In: KLUTE, A. Methods of soil analysis. 2. ed. Madison: American Society of Agronomy, part. 1, p. 635-662, 1986.

KLUTHCOUSKI, J.; FANCELLI, A. L.; DOURADO-NETO, D.; RIBEIRO, C.M.; FERRARO, L. A. . Manejo do solo e o rendimento de soja, milho, feijao e arroz em plantio direto. Scientia Agricola, Piracicaba, v. 57, p. 97-104, 2000.

LARCKER, W. Ecofisiologia Vegetal. São Carlos: RiMA, 2000. 531p.

LARSON, W.E.; GILL, W.R. Soil physical parameters for designing, new tillage systems. In: National Conservation Tillage Conference, 1, 1973, Ankeny, Anais...p.13-22.

LEONEL, C.L.; CENTURION, M.A.P.C.; CENTURION, J.F.; BEUTLER, A.N.; FREDDI, O.S. Relação da compactação do solo com a cultura do amendoim. Bioscience Journal, Uberlândia, v.23, p.70-81, 2007a.

LEONEL, C.L.; FREDDI, O.N.; BEUTLER, A.N.; CENTURION, M.A.P.C.; CENTURION, J.F. Influência da compactação do solo no crescimento radicular e na produtividade do amendoim. Científica, Jaboticabal, v.35, p. 51-60, 2007b.

LIMA, C.L.R.; PILLON, C.N.; SUZUKI, L.E.A.S.; CRUZ, L.E.C. Atributos físicos de um Planossolo Haplico sob sistema de manejo comparado aos do campo nativo. Revista Brasileira de Ciência do Solo, Viçosa, v.32, p. 1849-1855, 2008.

LORENZI, H. Plantas daninhas e seu controle na cana-de-açúcar. In: Reunião Técnica Agronomica Copersucar, 1983, Piracicaba. Anais...Piracicaba: Centro de Tecnologia Copersucar, 1983, p.59-73.

MALAVOLTA, E. Manual de nutrição mineral de plantas. São Paulo, Editora Agronômica Ceres, 2006. 638 p. 
MARCOLAN, A. L.; ANGHINONI, I. Atributos físicos de um argissolo e rendimento de culturas de acordo com o revolvimento do solo em plantio direto. Revista Brasileira de Ciência do Solo, Viçosa, v.30, n.1, p.163-170, 2006.

MATERECHERA, S.A.; ALSTON, A.M.; KIRBY, J.M.; DEXTER, A.R. Influence of root diameter on the penetration of seminal roots into a compacted subsoil. Plant Soil, Dordrecht, v.144, p.297-303, 1992.

MELLO IVO, W. M. P.; MIELNICZUK, J. Influencia da estrutura do solo na distribuição e na morfologia do sistema radicular do milho sob três métodos de preparo. Revista Brasileira de Ciência do Solo, Viçosa, v.23, p. 135-143, 1999.

MELOUK, H.A.; SHOKES, F.M. Peanut health management. St. Paul, Minnesota, 1995. 117p.

MENDONÇA, E.S.; ROWELL, D.L. Dinâmica do alumínio e de diferentes frações orgânicas de um latossolo argiloso sob cerrado e soja. Revista Brasileira de Ciência do Solo, Campinas, v.18, p.295-303, 1994.

MEROTTO, A.; MUNDSTOCK, C. M. Wheat root growth as affected by soil strength. Revista Brasileira de Ciência do Solo, Viçosa, v. 23, p. 197-202, 1999.

MERTEN, G. H.; MIELNICZUK, J. Distribuição do sistema radicular e dos nutrientes em Latossolo Roxo sob dois sistemas de preparo do solo. Revista Brasileira de Ciência do Solo, Campinas, v.15, p.369-374, 1991.

MEYER, B.S.; ANDERSON, D.B.; BOHMING, R.H. Introdução a Fisiologia Vegetal. Lisboa: Fundação Calourte Gulberkian, 1965. 564p.

MIELNICZUK, J. Matéria orgânica e a sustentabilidade de sistemas agrícolas. In: SANTOS, G.A.; CAMARGO, F.A.O. (Ed.). Fundamentos da matéria 
orgânica do solo. Ecossistemas tropicais e subtropicais. Porto Alegre, Genesis, 1999, p.1-8.

MIELNICZUK, J.; CARPENEDO, V.; PEDO, F. Desenvolvimento de raízes em solos compactados. Lavoura Arrozeira, Porto Alegre, v.38, p.42-43, 1985.

MILLER, D. E. Effect of subsoiling and irrigation regime no dry bean production in the Pacific Northwest. Soil Science Society of America Journal, Madison, v. 51, p.784-787, 1987.

MISRA, R. K.; DEXTER, A. R.; ALSTON, A. M. Maximum axial and radial growth pressures of plant roots. Plant and Soil, Hague, v.95, p.315-326, 1986.

MORAES, M. H.; BENEZ, S. H; LIBARDI, P. L. Efeitos da compactação em algumas propriedades físicas do solo e seu reflexo no desenvolvimento das raízes de plantas de soja. Bragantia, Campinas, v.54, p.393-403, 1995.

MOURA, R.M.; PEDROSA, E.M.R.; MARANHÃO, E.R.V.L.; MOURA, A.M.; MACEDO, M.E.A.; SILVA, E.G. Nematóides associados a cana-de-açúcar no estado de Pernambuco, Brasil. Nematologia Brasileira, Piracicaba, v.23, p.9299, 1999.

NOGUEIRA, S.S.S.; MANFREDINI, S. Influencia da compactação do solo no desenvolvimento da soja. Pesquisa Agropecuária Brasileira, Brasília, v.18, p. 973-976, 1983.

OADES, J. M. Soil organic matter and structural stability: mechanisms and implications for management. Plant and Soil, The Hague, v.76, n.1/3, p.319337, 1984.

OADES, J. M.; WATERS, A. G. Aggregate hierarchy in soils. Australian Journal of Soil Research, Melbourne, v.29, p.815-828, 1991. 
ORTOLAN, M.C.A. Rotação de culturas: amendoim/cana-de-açúcar. In: Seminarios Stab-Sul: Cana-de-açúcar e aguardente, 1979, Sertãozinho. Anais...Sertãozinho: STAB, p.9-16, 1979.

OVERBEER, J.V. Como vivem as plantas. São Paulo: Pioneira, 1970. 170p.

PABIN, J.; LIPIEC, J.; WODEK, S. Critical soil bulk density and strength for pea seedling root growth as related to other soil factors. Soil \& Tillage Research, Amsterdam, v.19, p.131-143, 1998.

PAULETTO, E. A.; GOMES, A. S.; NACHTIGALL, G. R. Produtividade do arroz irrigado em sistemas de cultivo contínuo e em rotação com soja e milho. In: REUNIÃO DA CULTURA DO ARROZ IRRIGADO, 18, 1989. Porto Alegre. Anais... Porto Alegre: IRGA, 1989. p. 150-160.

PAULINO, A.F.; MEDINA, C.C.; AZEVEDO, M.C.B.; SILVEIRA, K.R.P.; TREVISAN, A.A.; MURATA, I.M. Escarificação de um Latossolo Vermelho na pós-colheita de soqueira de cana-de-açúcar. Revista Brasileira de Ciência do Solo, Viçosa, v.28, p. 911-917, 2004.

PEDROTTI, A.; DIAS JÚNIOR, M. S. Compactação do solo: como evitá-la. Agropecuária Catarinense, v. 9, p. 50-52, 1996.

PRIMAVESI, A. Manejo Ecológico do solo: a agricultura em regiões tropicais. São Paulo: Nobel, 1987. 549p.

QUEIROZ-VOLTAN, R. B.; NOGUEIRA, S. S. S.; MIRANDA, M. A. C. Aspectos da estrutura da raiz e do desenvolvimento de plantas de soja em solos compactados. Pesquisa Agropecuária Brasileira, Viçosa, v. 35, p. 929-938, 2000.

RAIJ, B. van; CANTARELLA, H.; QUAGGIO, J. A.; FURLANI, A. M. C. Recomendações de adubação e calagem para 0 estado de São Paulo. Campinas: Instituto Agronômico/Fundação IAC, 1997. 285p. 
RAIJ, B. van; QUAGGIO, J. A.; CANTARELLA, H.; FERREIRA, M. .; LOPES, A. S.; BATAGLIA, O. C. Análise química do solo para fins de fertilidade. Campinas: Fundação Cargill, 1987. $170 \mathrm{p}$.

ROSOlEM, C. A.; ALMEIDA, A. C. da S.; SACRAMENTO, L. V. S. do. Sistema radicular e nutrição da soja em função da compactação do solo. Bragantia, Campinas, v. 53, p. 259-266, 1994.

ROSOLEM, C.A.; FOLONI, J.S.S.; TIRITAN, C.S. Root growth and nutrient accumulation in cover crops as affected by soil compaction. Soil and Tillage Research, Amsterdam, v.65, p.109-115, 2002.

ROSOLEM, C.A.; TAKAHASHI, M. Soil compaction and soybean root growth. In: BOX Jr, J.E. Root demographics and their efficiencies in sustainable agriculture, grasslands and forrest ecosystems. Dordrecht: Kluwer Academic Publishers, p.295-304. 1998.

ROTH, C.H.; CASTRO FILHO, C.; MEDEIROS, G.B. Análise de fatores físicos e químicos relacionados com a agregação de um Latossolo Roxo Distrófico. Revista Brasileira de Ciência do Solo, Campinas, v.15, p.241-248, 1991.

ROTH, C.H.; PAVAN, M.A. Effects of lime and gypsum on clay dispersion and infiltration in samples of a Brazilian Oxisol. Geoderma, Amsterdam, v.48, p.351-361, 1991.

SAXON, K.E.; McCOOL, D.K. \& KENNY, J.F. Tillage and residues impacts on infiltration. In: FOK, Y., (Ed). Infiltration principles and practices. Honolulu, Water Resources Research Center, 1988. p.509-513.

SECCO, D.; DA ROS, C.O.; SECCO, J.K.; FIORIN, J.E. Atributos físicos e produtividade de culturas em um latossolo vermelho argiloso sob diferentes sistemas de manejo. Revista Brasileira de Ciência do Solo, Viçosa, v. 29, p.407-414, 2005.

SECCO, D.; REINERT, D. J.; REICHERT, J. M.; DA ROS, C. O. Produtividade de soja e propriedades físicas de um latossolo submetido a sistemas de 
manejo e compactação. Revista Brasileira de Ciência do Solo, Viçosa, v.28, p. 797-804, 2004.

SIDIRAS, N.; VIEIRA, S.R.; ROTH, C.H. Determinação de algumas características físicas de um Latossolo Roxo distrófico sob plantio direto e preparo convencional. Revista Brasileira de Ciência do Solo, Campinas, v.8, n.3, p.265-8, 1984.

SILVA JÚNIOR, R. L. Variabilidade espacial do índice de cone correlacionada com mapas de produtividade. Piracicaba: ESALQ, 2001. 117p. (Dissertação de Mestrado).

SILVA, A.P.; KAY, B.D.;PERFECT, E. Characterization of the least limiting water range. Soil Science Society of America Journal, Madison, v. 58, p.1775-1781, 1994.

SILVA, I. F.; MIELNICZUK, J. Ação do sistema radicular de plantas na formação e estabilização de agregados do solo. Revista Brasileira de Ciência do Solo, Viçosa, v.21, p.113-117, 1997.

SILVA, I.F.; MIELNICZUK, J. Sistemas de cultivo e características do solo afetando a estabilidade de agregados. Revista Brasileira de Ciência do Solo, Viçosa, v.22, p.311-317, 1998.

SILVA, J.G. Ordens de gradagem e sistemas de aração do solo: desempenho operacional, alterações na camada mobilizada e respostas do feijoeiro (Phaseolus vulgaris L.). Botucatu: UNESP, 1992. 180p. (Tese de Doutorado).

SILVA, M. A. S. Propriedades físicas e teor de carbono orgânico de um argissolo vermelho sob distintos sistemas de uso e manejo. Revista Brasileira de Ciência do Solo, Viçosa, v. 30, p. 329-337, 2006. 
SILVA, M.L.N.; CURI, N.; BLANCANEAUX, P. Sistemas de manejo e qualidade estrutural de latossolo roxo. Pesquisa Agropecuária Brasileira, Brasília, v.35, p.2485-2492, 2000.

SILVA, R.H.; ROSOLEM,C.A. Crescimento radicular de soja em razão da sucessão de cultivos e da compactação do solo. Pesquisa Agropecuária Brasileira, Brasília, v.37, p. 855-860, 2002.

SILVA, V. R.; REINERT, D. J.; REICHERT, J. M. Densidade do solo, atributos químicos e sistema radicular do milho afetados pelo pastejo e manejo do solo. Revista Brasileira de Ciência do Solo, Viçosa, v.24, p.191-199, 2000.

SIX, J.; PAUSTIAN, K.; ELLIOTT, E.T.; COMBRINK, C. Soil structure and organic matter: I. Distribution of aggregatesize classes and aggregateassociated carbon. Soil Science Society American Journal, Madison, v.64, p.681-689, 2000.

SKELTON, B.J.; SHEAR, G.M. Calcium translocation in the peanut (Arachis hypogaea L.). Agronomy Journal, Madison, v.63, p.409-412, 1971.

SMITH, C. W.; JOHNSTON, M. A.; LORENTZ, S. The effect of soil compaction and soil physical properties on the mechanical resistance of South African forestry soils. Geoderma, Amsterdam, v. 78, p. 93-111, 1997.

SOUZA, Z.M.; PRADO, R.M.; PAIXÃO, A.C.S.; CESARIN, L.G. Sistema de colheita e manejo da palhada de cana-de-açúcar. Pesquisa Agropecuária Brasileira, Brasília, v.40, p. 271-278, 2005.

SPERA, S.T.; SANTOS, H.P.; FONTANELI, R.S. \& TOMM, G.O. Efeitos de sistemas de produção de grãos envolvendo pastagens sob plantio direto nos atributos físicos do solo e na produtividade. Revista Brasileira de Ciência do Solo, Viçosa, v.28, p. 533-542, 2004. 
STONE, L.F.; SILVEIRA, P.M. Efeitos do sistema de preparo e da rotação de culturas na porosidade e densidade do solo. Revista Brasileira de Ciência do Solo, Viçosa, v. 25, p. 395-401, 2001.

TARDIEU, F. Growth and functioning of roots and to root systems subjected to soil compaction. Towards a system with multiple signaling. Soil and Tillage Research, Amsterdam, v. 30, p. 217-243, 1994.

TAVARES FILHO, J.; BARBOSA, G. M.; GUIMARÃES, M. F.; FONSECA, I. C. B. Resistência à penetração e desenvolvimento do sistema radicular do milho (Zea mays) sob diferentes sistemas de manejo em um Latossolo Roxo. Revista Brasileira de Ciência do Solo, Viçosa, v.25, p.725-730, 2001.

TAVARES FILHO, J.; EIRA, G. C.; LUDWIG FARINHA, L.R. Avaliação da compactação em um solo cultivado no sistema convencional. Engenharia Agrícola, Jaboticabal, v19, p. 219-225, 1999.

THOMASSON, A. J. Towards an objective classification of soil structure. Journal of Soil Science, London, v.29, p. 38-46, 1978.

TISDALL, J.M.; OADES, L.M. Organic matter and water-stable aggregates in soil. Journal of Soil Science, Baltimore, v.33, p.141-163, 1982.

TORMENA, C. A., SILVA, A. P.; LIBARDI, P. L. Caracterização do intervalo hídrico ótimo de um Latossolo Roxo sob plantio direto. Revista Brasileira de Ciência do Solo, Viçosa, v.22, p.573-581, 1998.

TORMENA, C. A.; FRIEDRICH, R.; PINTRO, J. C.; COSTA, A. C. S. \& FIDALSKI, J. Propriedades físicas e taxa de estratificação de carbono orgânico num Latossolo Vermelho após dez anos sob dois sistemas de manejo. Revista Brasileira de Ciência do Solo, Viçosa, v.28, p.1023-1031, 2004.

TORRES, E.; SARAIVA, O. F. Camadas de impedimento do solo em sistemas agrícolas com soja. Londrina: Embrapa Soja, 1999. 58 p. (Embrapa Soja. Circular Técnica, 23). 
VEEN, B. W.; BOONE, F. R. The influence of mechanical resistance and soil water on the growth of seminal roots of maize. Soil and Tillage Research, Amsterdam, v.16, p.219-226, 1990.

VOLK, L.B.S.; COGO, N.P.; STRECK,E.V. Erosão hídrica influenciada por condições físicas de superfície e subsuperficie do solo resultantes do seu manejo, na ausência de cobertura vegetal. Revista Brasileira de Ciencia do Solo, Viçosa, v.28, p.763-774, 2004.

WENDLING, B.; JUCKSCH, I.; MENDONÇA, E.S.; NEVES, J.C.L. Carbono orgânico e estabilidade de agregados de um Latossolo Vermelho sob diferentes manejos. Pesquisa Agropecuária Brasileira, Brasília, v.40, p.487-494, 2005.

WOHLEMBERG, E.; REICHERT, J.M.; REINERT, D.J.; BLUME, E. Dinâmica da agregação de um solo franco arenoso em cinco sistemas de culturas em rotação em sucessão. Revista Brasileira de Ciência do Solo, Viçosa, v.28, p.891-900, 2004.

WRIGHT, F.S. Alternate tillage practices for peanut production in Virginia. Peanut Science, Dawson, v.18, p. 9-11, 1991.

WRIGHT, F.S.; PORTER, D.M. Digging date and conservational tillage influence on peanut production. Peanut Science, Dawson, v.18, p.72-75, 1991.

YODER, R.E. A direct method of aggregate analysis of soil and a study of the physical nature of erosion losses. Journal of American Society of Agronomy, New York, v.28, p.337-357, 1936.

ZONTA, E.; BRASIL, F.C.; GOI, S.R.; ROSA, M.M.T. O sistema radicular e suas interações com o ambiente edáfico. In: FERNANDES, M. S. Nutrição mineral de plantas. Viçosa, MG: Sociedade Brasileira de Ciência do Solo, 2006. p. 07-52. 